\title{
Self-Defense and Subjectivity
}

\author{
V.F. Nourse $\dagger$
}

Of all the oppositions that artificially divide social science, the most fundamental, and most ruinous, is the one that is set up between subjectivism and objectivism.'

The law of self-defense has rarely produced as much academic or popular heat as it has in the past two decades. Widely publicized trials, such as the Goetz and Menendez cases, ${ }^{2}$ have generated deep-seated fears of a law unmoored from principle. Those fears have generated a standard public critique - that the criminal law has become too soft and subjective, too wedded to syndrome science and prone to weakkneed affection for defendants. The criminal law has lost its "objectivity," so the argument goes. The poster child, and even the alleged cause of this development, is the battered woman.

In this Article, I present evidence that much of this public debate is misdirected: the charge of subjectivity and abuse, if not a deception,

$\dagger$ Associate Professor of Law, University of Wisconsin. I want to thank the participants at faculty workshops at both the University of Chicago and the University of Michigan for engaging with the ideas presented in early drafts of this paper. Special thanks to Juliet Brodie, Tom Green, Martha Ertman, Don Herzog, Dan Kahan, Jane Schacter, Stephen Schulhofer, and Cass Sunstein for asking the interesting and important questions. My research assistants worked valiantly and under pressure; they deserve enormous credit for the final product. My heartfelt appreciation to Vanessa Tanaka, Daniel Fulkerson, and Roseann Kitson, for reading so many cases, and to Khanitta Tanawirattananit, for expert statistical assistance.

1 Pierre Bourdieu, The Logic of Practice 25 (Stanford 1980).

2 See George P. Fletcher, Domination in the Theory of Justification and Excuse, $57 \mathrm{U}$ Pitt L Rev 553, 571-76 (1996) (discussing the controversy surrounding the trial of Lyle and Erik Menendez). For a general discussion of the Goetz case, see George P. Fletcher, A Crime of SelfDefense: Bernhard Goetz and the Law on Trial (Free Press 1988).

3 See, for example, James Q. Wilson, Moral Judgment: Does the Abuse Excuse Threaten Our Legal System? 62-66, 101-12 (Basic 1997) (urging that the criminal law has become too "subjective" and reflects undue sympathy toward disadvantaged "groups"). See also Donald Alexander Downs, More Than Victims: Battered Women, the Syndrome Society, and the Law 6-7 (Chicago 1996) (decrying the development of a "syndrome" society); Alan M. Dershowitz, The Abuse Excuse and Other Cop-Outs, Sob Stories, and Evasions of Responsibility 18-19 (Little, Brown 1994) (decrying the increasing number of "abuse" excuses).

4 See Wilson, Moral Judgment at 63 (cited in note 3) (arguing that battered woman claims are examples of the criminal law's unwarranted affection for "subjective" defenses); David $L$. Faigman and Amy J. Wright, The Battered Woman Syndrome in the Age of Science, 39 Ariz L Rev 67,79 (1997) (arguing that "[t]he integrity of legal doctrine has suffered immensely" from the spread of syndrome evidence aimed at aiding battered women); Downs, More Than Victims at 350 (cited in note 3) (arguing that battered woman syndrome claims have helped to nurture a "syndrome" society); Dershowitz, Abuse Excuse at 17, 25 (cited in note 3) (arguing that some battered woman claims may be classified as an abuse excuse). 
is a diversion. The problem with the law of self-defense is neither new nor limited to the battered woman; it is as old and as persistent as the law's search for an objective meaning for necessity. Based on a survey of twenty years of self-defense cases, I sought to "test" claims of objectivity by focusing on what purports to be one of the most objective of self-defense rules: the requirement that the threat must have been "imminent" for the defendant's response to have been permissible." Time is not something legal scholars generally study.' I chose to study imminence, however, because it seems the quintessential definition of "objectivity," the hard case. Perhaps more importantly, there is no more controversial element in the law of self-defense. As George Fletcher has put it: "The central debate in the theory of self-defense for the last decade has been whether we should maintain a strict requirement of imminence.",

My survey shows that the important question is not whether the law has become too soft or subjectified but what we mean by its objectivity. The case law shows that imminence has many meanings; indeed, imminence often operates as a proxy for any number of other selfdefense factors - for example, strength of threat, retreat, proportionality, and aggression. Perhaps more importantly, my survey shows that

5 My survey includes all self-defense cases between 1979 and 1999 that discuss or note the issue of imminence as an issue at trial or on appeal. My focus is not on battered women, but selfdefense cases in general. Moreover, my empirical claim is only that the law's image of imminence, to the extent it is tied to a particular factual pattern (defendants who wait to kill), is highly unlikely to be representative of self-defense claims. For an article focusing specifically on the battered woman cases, see Holly Maguigan, Battered Women and Self-Defense: Myths and Mis. conceptions in Current Reform Proposals, 140 U Pa L Rev 379 (1991) (offering a different empirically based study of self-defense).

6 Self-defense law typically requires a showing of an "imminent" threat. Wayne R. LaFave, Criminal Law $\$ 5.7$ (d) at 495-96 (West 3d ed 2000) (describing the imminence requirement). On the "objectivity" of this requirement, see Fletcher, 57 U Pitt L Rev at 561 (cited in note 2) ("II]mminence, necessity and proportionality-speak to the objective characteristics of" selfdefense claims.).

7 There is one important exception to this in the criminal law: Mark Kelman's brilliant argument about "time framing," which may be found generally in Mark Kelman, Interpretive Construction in the Substantive Criminal Law, 33 Stan L Rev 591 (1981). His argument shows, I believe, that the meaning of time in the criminal law is incomplete. Here, my claim is that time's completeness and its coherence depend upon undeclared social norms about the relationships between the defendant and the victim and between the defendant and the state.

8 Fletcher, 57 U Pitt L Rev at 567 (cited in note 2). Many assume that battered woman cases routinely fail the imminence requirement. See, for example, Cathryn Jo Rosen, The Excuse of Self-Defense: Correcting a Historical Accident on Behalf of Battered Women Who Kill, $36 \mathrm{Am}$ U L Rev 11, 43 (1986) (stating that "[m]ost battered woman's defense cases involve situations in which the defendant was not, in fact, in imminent danger of death or serious bodily harm at her victim's hands"). See also note 30 . There is reason to doubt this assumption. See Maguigan, 140 U Pa L Rev at 388-97 (cited in note 5) (presenting empirical evidence challenging this view). Much of the legal commentary on self-defense has focused on the imminence requirement. See, for example, Fletcher, 57 U Pitt L Rev at 556-58 (cited in note 2) (arguing that imminence is essential to self-defense doctrine). 
the conventional image of imminence may be incorrect. It is widely believed by scholars that the "problem" of imminence is one of too much time between the threat and the killing. If my survey is right, however, most judicial opinions raising imminence do not involve long periods of time between the threat and the killing. They are cases of weak threats and extended fights, cases in which the defendant is struggling with the victim, is faced with a gun, believes that the victim is advancing, or hears a stranger in the woods outside his home.' This should confound traditional doctrinal understandings of the term "imminence" (which presume imminence as relevant only in nonconfrontational "waiting" cases). Indeed, it presents strong evidence supporting my hypothesis - that imminence carries undeclared meanings.

This has important implications for both the law of self-defense as well as our image of the problem of battered women. The law of self-defense, if I am right, is far from as settled or coherent as it is assumed to be; its meaning and theory remain, in my view, largely unresolved. What seems so objective-the status quo-turns out to be a good deal more complex and contingent than has been assumed. Indeed, it is even possible that the law, through imminence, contradicts itself: for example, if imminence is really asking whether the defendant had a means to escape the violence, it may function as a retreat rule in jurisdictions that do not require retreat. ${ }^{10}$ What is more interesting is that this failure of objectivity - the potential for contradiction-predicts the possibility of injustice in the battered woman cases.

It turns out that the battered woman cases in my survey, like their male counterparts, "raise imminence most often in confrontational situations, where the defendant kills when she sees a gun, where the victim is advancing, or during an actual brawl. ${ }^{12}$ If that is right, then the

9 See, for example, Commonwealth $v$ Stonehouse, $521 \mathrm{~Pa} 41,555$ A2d 772, 780 (1989) (describing claim in which defendant asserts that when she shot, the defendant was pointing a gun at her); State v Negrin, 37 Wash App 516, 681 P2d 1287, 1290 (1984) (describing claim in which defendant shoots into woods because he hears rustling in the bushes); Commonwealth $v$ Watson, $494 \mathrm{~Pa}$ 467, 431 A2d 949, 951 (1981) (describing claim in wl ich parties were struggling).

10 Jurisdictions are divided on whether a legitimate $c$ aim of self-defense requires that the defendant have "retreated" once the attack has begun. A majority of jurisdictions do not require retreat. See LaFave, Criminal Law \$ 5.7(f) at 497-99 (cited in note 6) (discussing the retreat rule). For a discussion of the history and importance of this issue, see Dan M. Kahan, The Secret Ambition of Deterrence, 113 Harv L Rev 413, 429-35 (1999).

11 This Article does not address at length the question of the battered woman who, in fact, does "wait" to kill. This is not an evasion, but simply a recognition that concentration on these cases may well have occluded more serious problems in the law of self-defense, both for battered women and for others.

12 See, for example, State v Sallie, 81 Ohio St 3d 673,693 NE2d 267, 270 (1998) (recounting defendant's testimony that the victim "attacked her and, as he was choking her, threatened to kill her," and she responded); Smith v State, 268 Ga 196, 486 SE2d 819, 821 (1997) (describing defendant's claim that, during the fight, victim continued to hit and hold a metal can over her head just

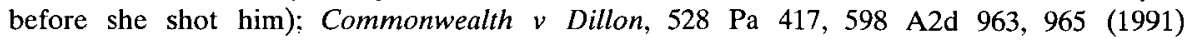


problem of the battered woman case may not be one of fact, but of law. We do not ask of the man in the barroom brawl that he leave the bar before the occurrence of an anticipated fight, but we do ask the battered woman threatened with a gun why she did not leave the relationship..$^{13}$ If, when courts are saying "imminence," they import meanings that demand retreat before the confrontation, they are applying a rule that the law itself disavows (for any defendant). ${ }^{14}$ And, if that is right, we need not subjectify the law for the disfavored; instead, we must deal with the potential for objective rules to contradict themselves, to perpetuate meanings that they disavow.

This is not only an argument about the law of self-defense but also an argument of objective, yet constitutive, feminism ${ }^{15}$ - an argument that uses traditional claims of objectivity to predict the ways in which the law embraces social meaning and thus constitutes gender inequity. We might have known from other disciplines, or even the history of the criminal law, that time "works," that it has meaning in the law of self-defense. It should be no surprise, really, that if the objective rules have meaning, that they may absorb social meanings and that those meanings may incorporate assumptions about women's relationship to men.

("[A]ppellant testified that the decedent ... grabbed her by the arm, pushed her, punched her and told her he was going to kill her just prior to her stabbing him."), affd in part, vacd in part as Commonwealth v Miller, 430 Pa Super 297, 634 A2d 614 (1993).

13 See, for example, Stonehouse, 555 A2d at 783 (noting that the prosecutor "stressed to the jury in his closing argument that if appellant had truly been an innocent victim she could put an end to the relationship"), revg Commonwealth v Stonehouse, 358 Pa Super 270, 517 A2d 540, 544 (1986) (stating that "[t]he continued relationship between appellant and the victim further points to how unreasonable appellant's assertion of self-defense is. Appellant had ample time and opportunity to have the victim arrested."). The facts of the case are lengthy, but see Stonehouse, 555 A2d at 780 ("As she leaned over the railing, appellant saw Welsh on the ground below aiming his gun at her. Believing that she heard a shot, appellant fired her gun twice.").

14 Do not confuse this with a statement about the law of retreat-a minority of jurisdictions demand that the defendant leave the scene of confrontation once it has begun. It has never been the law of self-defense, however, that a defendant who is being choked should be denied the defense because he was "in the wrong place" at the wrong time-whether in a violent town or bar or street corner, much less in the wrong home. See text accompanying notes 235-39 (discussing this principle at greater length). Moreover, courts have consistently disavowed the notion that "leaving the relationship" is the proper legal standard in battered woman cases. See text accompanying notes 223 .

15 My intellectual method here is, admittedly, not a method of engagement but of distance. I am attempting to "step back from our initial view" of the topic of self-defense and subjectivity and "form a new conception which has that view and its relation to the world as its object." Thomas Nagel, The View from Nowhere 4 (Oxford 1986). This is not a recommendation for all legal studies or an insult to the many wise and wonderful approaches that emphasize experiential or multiple viewpoints. It is a means, self-consciously chosen, to challenge an orthodoxy by the very methods that it chooses and the only methods that it recognizes. At the same time, the argument I am making is, like much feminist scholarship, constitutive: it asks how law constitutes the relation of woman to others and to the state. 
And yet we continue to argue about all this in terms that make the rules' absorption of social meanings very difficult to see. In selfdefense and elsewhere, the discourse of subjectivity and objectivity gives challengers only one way to disagree (special rules), ${ }^{16}$ and then brands the argument as unfair and partial. Objectivity, alone, tells us nothing - it is radically incomplete without a specification of the ways the law incorporates and creates social meanings. ${ }^{17}$ Without that content, the debate about subjectivity and self-defense becomes an empty exercise, a set of vague assertions of power and charges of lawlessness.

Part I of this Article explains the legal issues of imminence and the law of self-defense as well as the construction of the legal debate as a question of subjectivity. Part II presents the results of my survey and its method. Part III argues that the so-called objectivity of contemporary doctrine is belied by its content; that doctrine we call "objective" leaves open many questions and risks the embrace of contradictions. This Part traces these failures to a basic theoretical disagreement about the meaning of necessity in the law of self-defense. Part IV argues that "subjectivity" cannot resolve these questions. It argues that even the apparently most subjective aspects of self-defense lawsuch as battered woman syndrome-may rest on objective legal propositions. Finally, Part V questions whether a discourse of objectivity and subjectivity really helps us understand the criminal law, in selfdefense or the many other places it may be found. ${ }^{18} \mathrm{I}$ argue that if there is a problem with the law of criminal defenses today, it is not with syndromes or subjectivity, but with a criminal law that purports to be neutral and precise but remains full of contested meanings.

\section{The Modern Construction OF SELF-Defense}

It is widely assumed today that the law of self-defense is quite settled and that the hornbook elements of a self-defense claim are well-established. As a general rule, a defendant makes out a claim of self-defense when he shows that he was confronted by a serious threat of bodily harm or death, the threat was imminent, and his response was both necessary and proportionate. ${ }^{19}$ This general principle is then

16 See, for example, Fletcher, 57 U Pitt L Rev at 554 (cited in note 2) (posing the question as "whether special rules should apply on behalf of women who kill those who have persistently battered them in the past").

17 See Nagel, View from Nowhere at 6 (cited in note 15) (arguing that objectivity "cannot by itself provide a complete picture of the world, or a complete stance toward it").

18 In its focus on objectivity and subjectivity, the law of self-defense is hardly unique. One can see similar debates on a variety of legal topics within the criminal law, including cases on provocation or negligence, or in other disciplines entirely. But, in the law of self-defense, it is thought that much hangs upon the distinction. Indeed, it is thought that the most controversial cases, although small in number, depend upon it.

19 See LaFave, Criminal Law \$ 5.7(a)-(d) at 491-96 (cited in note 6). 
qualified by two features that may bar some claims: if the defendant provoked the violence or was the "initial aggressor," he may lose his right to claim self-defense. ${ }^{20}$ More controversially, in a substantial minority of jurisdictions, the defendant will lose a self-defense claim if he fails to retreat in circumstances where it was safe to do so. ${ }^{21}$

\section{A. Time, Subjectivity, and Self-Defense}

If there is a debate within the criminal law academy about selfdefense today, it does not focus on the content of the doctrine. Instead, it focuses on whether the legal standard should be more "objective",22 or "subjective." ${ }^{, 23}$ Conventional wisdom has it that the principal issue in self-defense cases is whether we should apply a rule that focuses on the particular defendant or one that imposes the standards of the "reasonable person.," This apparent dichotomy has had an enormous influence on modern teaching and case law. In many a self-defense case, defendants argue that the jury instructions granted were too "objective," the State responds that they were "subjective" enough, and

$20 \quad$ See id $\$ 5.7(\mathrm{e})$ at 497.

21 See id $\$ 5.7($ f) at $497-99$

22 I use "objectivity" here in ways that are traditional in legal literature. For a thoughtful account, see George P. Fletcher, Rethinking Criminal Law 504-14 (Little, Brown 1978) (attempting to dispel prevailing "confusion [regarding] the notions of objectivity and subjectivity in the theory of liability"). I am not using this term in the relatively more disciplined sense used in philosophical debate. For a general discussion, see Judith Jarvis Thomson, Self-Defense, 20 Phil \& Pub Aff 283 (1991) (exploring the question of when killing in self-defense might be justified through a series of illustrative examples). See also Russell Christopher, Self-Defense and Objectivity: A Reply to Judith Jarvis Thomson, 1 Buff Crim L Rev 537, 538 (1998) (arguing "that a careful analysis of Thomson's approach yields conclusions diametrically opposite to those which she claims").

23 The "subjectivity" to which I refer in this Article is that associated with its meaning in criminal law, not its meaning elsewhere (including feminism or postmodernism). For an example of the traditional criminal law distinction between subjectivity as "state of mind" versus objectivity as an external "judgment" of conduct, see Kenneth W. Simons, Self-Defense, Mens Rea, and Bernhard Goetz, 89 Colum L Rev 1179, 1186-88 (1989) (reviewing Fletcher, A Crime of SelfDefense (cited in note 2)). The precise nature of subjectivity is an interesting and difficult question and one debated and discussed at length among feminists and others. See, for example, Catharine A. MacKinnon, Toward Feminist Jurisprudence, 34 Stan L Rev 703 (1982) (reviewing Ann Jones, Women Who Kill (Holt, Rinehart \& Winston 1980)).

24 This is often reflected in casebooks and appellate opinions. See, for example, cases cited in notes 25 and 26. See also John Kaplan, Robert Weisberg, and Guyora Binder, Criminal Law: Cases and Materials 630-38 (Little, Brown 3d ed 1996); Sanford H. Kadish and Stephen J. Schulhofer, Criminal Law and Its Processes: Cases and Materials 801-26 (Aspen 6th ed 1995).

25 See, for example, State v Bellino, 31 Conn App 385, 625 A2d 1381, 1383-84 (1993) (noting the defendant's argument that the trial court's jury instructions "regarding the subjective aspect of the self-defense inquiry" were erroneous; rejecting this argument on the ground that the jury must determine not only the "subjective" belief of the defendant but must also "determine whether that belief was reasonable"). 
the court most often concludes that the standard requires both objectivity and subjectivity.

This dichotomy between subjective and objective approaches has, in turn, come to shape our vision of the problems of self-defense law. In an attempt to generate discussion about the wisdom of a more or less subjective standard, casebooks routinely juxtapose a case involving a battered woman claiming a subjective rule with a case that pushes that rule to encompass a far less sympathetic defendant. ${ }^{27}$ The central image of the debate is often the sad tale of Judy Norman, ${ }^{28}$ or a case like hers, of a woman who killed her partner while asleep or hours after the last bout of violence. Often, the foil to this drama is the unpalatable racist, such as Bernhard Goetz, the subway vigilante. Students who sympathize with the battered woman are questioned about whether they are prepared to defend a subjectified legal standard if they know that this will mean aid for those, such as Goetz, to whom they are generally unsympathetic.

The debate over the "subjective" is often associated with an empirical assumption about the nature of battered woman cases-that the facts don't quite measure up. In particular, the facts are thought not to "measure up" primarily because they fail to meet the legal doctrine's requirement for an imminent threat. ${ }^{30}$ Given this, it is not sur-

26 See, for example, id at 1384 ("It is settled that a jury's evaluation of a claim of selfdefense has both subjective and objective elements."). See also State $v$ Walker, 136 Wash 2d 767, 966 P2d 883, 886 (1998) ("With both subjective and objective aspects taken into account, the trial judge must determine whether the defendant produced any evidence to support his claimed good faith belief that deadly force was necessary and that this belief, viewed objectively, was reasonable."). As Holly Maguigan notes, appellate courts sometimes obscure this dualism by using misleading terms for their own standards, using the term "subjective," for example, to describe a standard that is both subjective and objective, or using the term "objective" to describe a similar standard. Maguigan, $140 \mathrm{U}$ Pa L Rev at 410 (cited in note 5) (stating that "[ $t$ ]he combined nature of the standard actually used by a majority of the states is sometimes obscured by the label a state's highest court has attached to it").

27 See, for example, Ronald N. Boyce and Rollin M. Perkins, Criminal Law and Procedure 940-54 (Foundation 8th ed 1999) (contrasting a battered wife case with that of Bernhard Goetz); Kaplan, Weisberg, and Binder, Criminal Law at 609-36 (cited in note 24) (same); Phillip E. Johnson, Criminal Law: Cases, Materials, and Text 379-88 (West 5th ed 1995) (contrasting a battered wife case with a case in which the defendant killed his Asian neighbor, irrationally fearing a martial arts attack).

28 Norman killed her husband while he was asleep, hours after the last bout, after enduring years of degrading abuse in which she was prostituted, deprived of food, made to sleep on the floor, and driven to attempt suicide. The North Carolina court denied a jury instruction based on self-defense. State v Norman, 324 NC 253, 378 SE2d 8, 9-10, 19 (1989). Legal scholarship has been at pains to try to grapple with Norman; entire symposia have been conducted on the theory that Norman's problem is the central problem of battered women and the law of self-defense. See, for example, Symposium, Self-Defense and Relations of Domination: Moral and Legal Perspectives on Battered Women Who Kill, 57 U Pitt L Rev 461 (1996).

29 For a general discussion of the Goetz case, see Fletcher, Crime of Self-Defense (cited in note 2).

30 See, for example, David L. Faigman, Note, The Battered Woman Syndrome and Self- 
prising that the legal concept of imminence has come to occupy a "central" place in the debate over the law and theory of self-defense. That debate, as currently envisioned, pits "objectivists," who argue that a strict imminence requirement is important to the law of selfdefense," against "subjectivists," who appear to argue that the law should be "loosened" for battered women."

\section{B. Time as Meaningful}

Much of this debate appears to proceed on the assumption that the meaning of the term "imminence" is self-evident. Treatises and law reviews tell us that " $[t]$ he requirement of imminence means that the time for defense is now. The defender cannot wait any longer." ${ }^{34}$ Similarly, force is "imminent" if it will occur "almost immediately,",35 "upon the instant," or "at once." "Legitimate self-defense must be neither too soon nor too late." Although the Model Penal Code sought to change this rule, and potentially soften it, by shifting the requirement from the threat (as "imminent") to the response (as "immediately necessary"), this approach has done little to change the basic assumption that we are still talking about temporal matters.

Defense: A Legal and Empirical Dissent, 72 Va L Rev 619, 621 (1986) ("Frequently, however, a battered woman kills her mate after an attack has ended or at some time when, seemingly, no immediate threat is present."); Rosen, $36 \mathrm{Am}$ U L Rev at 13 (cited in note 8) (noting that, often, "[d]espite the defendant's long-term victimization, she most likely would not have been killed or subjected to serious bodily injury on the occasion when she killed her abuser"). In fact, appellate judges have repeated these claims. See, for example, State $v$ Koss, 49 Ohio St 3d 213, 551 NE2d 970, 977 (1990) (Holmes concurring), quoting Rosen, 36 Am U L Rev at 43 (cited in note 8) ("Most battered woman's defense cases involve situations in which the defendant was not, in fact, in imminent danger of death or serious bodily harm at her victim's hands.").

31 Fletcher, 57 U Pitt L Rev at 567 (cited in note 2).

32 See id at 561 (describing imminence as an objective characteristic of self-defense law). See also id at 554 (framing the question raised by feminists as whether "special rules" are necessary to protect battered women).

33 See LaFave, Criminal Law $\$ 5.7$ (d) at 496 (cited in note 6) (discussing the conventional debate about imminence and battered woman syndrome, citing relevant authorities).

34 Fletcher, $57 \mathrm{U}$ Pitt L Rev at 556 (cited in note 2) (emphasis added).

35 LaFave, Criminal Law \& 5.7(d) at 495 (cited in note 6). Indeed, some of the most wellknown appellate decisions in this area have appeared to turn upon the difference between the terms "immediate" and "imminent." See, for example, People v Aris, 215 Cal App 3d 1178, 1187, 264 Cal Rptr 167, 173 (1989) ("Defense counsel's objection was that the terms 'imminent' and 'immediate' must be differentiated, defining immediate as 'something next in order, about to occur' and 'more happening right away' and defining imminent as 'more of a threatening and impending ... and impending is something that might or is about to occur."'), overruled in part by People v Humphrey, 13 Cal 4th 1073, 921 P2d 1 (1996). See also State v Hundley, 236 Kan 461, $693 \mathrm{P} 2 \mathrm{~d} 475,478$ (1985) ("Thus, the question is whether the instruction allows the jury to consider 'all the evidence' or whether the use of the word 'immediate' rather than 'imminent' precludes the jury's consideration of the prior abuse.").

36 Joshua Dressler, Understanding Criminal Law 206 (Matthew Bender 2d ed 1995).

37 Fletcher, $57 \mathrm{U}$ Pitt L Rev at 556 (cited in note 2).

38 MPC $\$ 3.04$ (ALI 1962). See Paul H. Robinson, 2 Criminal Law Defenses $\S 131$ (c) at 78 
There is reason to doubt the confidence with which the conventional notion of imminence as "the now" is asserted, either as a general matter or as a matter of criminal law. To students of other disciplines-philosophy, history, and even physics ${ }^{39}$ - the notion that time has meaning is far from odd. Social scientists, for example, have shown us that different cultures have very different ideas of time, indeed, that different institutions and occupations create different "norms" of time. Scientists have explained that the meaning of time may depend upon our reference point and that space and time may be inevitably conjoined. ${ }^{42}$ Behavioral economists have shown that the sense of time and rewards may be crucial in assessing and predicting behavior. ${ }^{43}$ Social theorists have explained that temporal frameworks give social practices "form," that time gives social practices their "direction and meaning." "Philosophers have argued that the idea of the "now" is essentially incomplete from an objective point of view. ${ }^{45}$

Moreover, there is a very ancient tradition in which time carries meaning in the criminal law, in particular the law of murder and selfdefense. Although categories like imminence in self-defense and "cooling time" in provocation are principally nineteenth-century creations, time was essential to the early common law of murder, drawing the line between murder and manslaughter. ${ }^{46}$ The malice necessary for

(West 1984) (explaining the MPC's preference for the "immediately necessary" language over "imminent" alternative, taken by "[m]any states").

39 For modern efforts in this regard, see generally Michael G. Flaherty, $A$ Watched Pot: How We Experience Time (NYU 1999) (social and cultural perceptions of time); Philip Turetzky, Time (Routledge 1998) (history of the philosophy of time); Robert Levine, A Geography of Time (Basic 1997) (social psychologist's view of time); Barbara Adam, Timewatch:The Social Analysis of Time (Polity 1995) (how individuals and culture address time). Einstein's relativity theory has, of course, put time into contention even in the sciences.

40 For a general discussion, see Adam, Timewatch (cited in note 39); Levine, Geography of Time (cited in note 39); Flaherty, $A$ Watched Pot (cited in note 39).

41 See, for example, Cynthia Fuchs Epstein et al, The Part-Time Paradox: Time Norms, Professional Life, Family, and Gender (Routledge 1999) (analyzing a study of the experiences lawyers in different types of practices have had with part-time work).

42 For a general discussion, see Albert Einstein, The Meaning of Relativity (Princeton 5th ed 1956).

43 Christine Jolls, Cass R. Sunstein, and Richard Thaler, A Behavioral Approach to Law and Economics, 50 Stan L Rev 1471, 1538-39 (1998) (arguing that criminals tend to calculate costs and benefits over time in deciding whether to commit criminal acts, though suggesting that the calculating rationality is bounded by "problems of self-control").

44 Bourdieu, Logic of Practice at 98 (cited in note 1). See id at 106 ("[T]ime derives its efficacy from the state of the structure of relations within which it comes into play.").

45 Nagel argues:

There is no room in a fully objective description of the world for the identification of a particular time as the present... Yet the fact that it is now the particular time that it is seems to be a fundamental truth which we cannot do without. The tenseless description of the temporal order is essentially incomplete, for it leaves out the passage of time.

Nagel, View from Nowhere at $57 \mathrm{n} 1$ (cited in note 15).

46 See, for example, Sir Matthew Hale: 
unexcused homicide was taken to be a "settled anger (which requires some length of time)." sudden affray or upon a sudden passion. ${ }^{48}$ Even today, this is still the line-a line conceived in time-that marks the difference between provoked homicide and first-degree murder in many jurisdictions.

Time has particular historical importance not only for the law of murder but also for the law of self-defense. Indeed, temporality is central to the common law distinction between excused and justified selfdefense. Blackstone ${ }^{49}$ imagined two classic self-defense situations-in one, the defendant prevented a felony and was justified; in the other, the defendant was in the midst of a fight and was merely excused. The upstanding citizen who sought to prevent a felony ${ }^{51}$ was not only blameless but deserved commendation; ${ }^{52}$ as an agent of the law, he was

If A. and B. fall suddenly out, and they presently agree to fight in the field, and run and fetch their weapons, and go into the field and fight, and A. kills B. this is not murder but homicide [Hale defines homicide as something less than murder], for it is but a continuance of the sudden falling out, and the blood was never cooled, but if there were deliberation, as that they meet the next day, nay, tho it were the same day, if there were such a competent distance of time, that in common presumption they had time of deliberation, then it is murder.

Sir Matthew Hale, 1 The History of the Pleas of the Crown*453 (Professional 1971) (emphasis added) (originally published 1680 ).

$47 \quad R$. v Oneby, 92 Eng Rep 465 (KB 1727) (Holt).

48 See Hale, 1 History of the Pleas of the Crown at 449 (cited in note 46) ("Murder and manslaughter differ not in the kind or nature of the offense, but only in the degree, the former being the killing of a man of malice prepense, the latter upon a sudden provocation and falling out.") (emphasis added).

49 William Blackstone, 4 Commentaries on the Laws of England *182-86 (Chicago 1979) (originally published 1769). My account here focuses on Blackstone, a principal influence in America, but its history is consistent with earlier English common law writers on the split theory of self-defense. See, for example, Hale, 1 History of the Pleas of the Crown at *491-95 (cited in note 46) (distinguishing between se defendendo and killings of felons).

50 The justificatory form of self-defense law was called "prevention of a felony"; the excuse form was deemed a plea of "se defendendo." Scholars have known of this two-headed version of self-defense for some time but have differed on their interpretations of Blackstone, mostly concerning the necessity of retreat. Beale, at the turn of the century, claimed that retreat should be applied to both excused and justified self-defense. Joseph $\mathrm{H}$. Beale, Jr., Retreat from a Murderous Assault, 16 Harv L Rev 567, 580-82 (1903). Perkins disputed this understanding (rightly in my view), arguing that retreat, in Blackstone's view, was limited only to those situations in which there was "fault" for entering the affray. Rollin M. Perkins, Self-Defense Re-examined, 1 UCLA L $\operatorname{Rev} 133,139-45$ (1954).

51 This was not the only version of "justified" self-defense; also justified were homicides that Blackstone dubbed as ones for the "advancement of public justice." See Blackstone, 4 Commentaries at *178-82 (cited in note 49) (listing as "justified" homicides those committed by an executioner, those committed by an officer of the government, and those that involve "prevention of any forcible and atrocious crime" by a private party); id at *183-84:

Homicide in self-defence, or se defendendo, upon a sudden affray, is also excusable rather than justifiable, by the English law. This species of self-defence must be distinguished from that just now mentioned, as calculated to hinder the perpetration of a capital crime; which is not only a matter of excuse, but of justification.

52 For this reason, Blackstone would go so far as to say that one who killed to prevent a 
unbound by special rules about "sudden" affrays, or retreating to the wall. ${ }^{53}$ Not so the brawler whose claim was one of culpable necessity. The brawler needed to show that he killed for the right motives and without offense to legal authority, to negate his partial responsibility for entering into mutual combat. ${ }^{5.5}$ Suddenness featured prominently in that calculus. ${ }^{56}$ The sudden affray excused the brawler's failure to seek "recourse to the proper tribunals," suggested that he had not killed out of a "previous malice and concerted design," and confirmed that

felony, to thwart a robbery or a burglary or even an unjustified attack, was "in no kind of fault whatsoever, not even in the minutest degree; and is therefore to be totally acquitted and discharged, with commendation rather than blame." Id at * 182 .

53 Retreat was specifically aimed, in the case of the brawler, to temper the defendant's culpability for entering the affray. See, for example, People v Fowler, $178 \mathrm{Cal} 657,174 \mathrm{P} 892,897$ (1918) (stating that " $[\mathrm{t}]$ wo men being in the wrong, neither can right himself except by retreating to the wall") (internal quotation marks omitted). See also Perkins, 1 UCLA L Rev at 139-45 (cited in note 50) (discussing the relationship between fault and retreat at early English common law).

54 Blackstone, 4 Commentaries at *186-87 (cited in note 49 ). Comparing se defendendo with misadventure, Blackstone states:

And as to the necessity which excuses a man who kills another se defendendo, Lord Bacon entitles it necessitas culpabilis, and thereby distinguishes it from the former necessity of killing a thief or a malefactor. For the law intends that the quarrel or assault arose from some unknown wrong, or some provocation, either in word or deed: and since in quarrels both parties may be, and usually are, in some fault; and it scarce can be tried who was originally in the wrong; the law will not hold the survivor intirely [sic] guiltless.

Id (citation omitted).

55 Because the defendant was partially at fault, his plea did not lead to automatic exoneration, but conviction with a likely pardon (as a matter of grace). See Thomas A. Green, The Jury and the English Law of Homicide, 1200-1600, 74 Mich L Rev 413, 425 (1976); Perkins, 1 UCLA L Rev at 141-42 (cited in note 50). Both se defendendo and provoked manslaughter rely upon the notion of chance-medley. See Blackstone, 4 Commentaries at *184 (cited in note 49) (noting the difficulty of distinguishing homicide upon chance-medley and manslaughter).

56 Blackstone, 4 Commentaries at *184 ("But the self-defence, which we are now speaking of, is that whereby a man may protect himself from an assault, or the like, in the course of a sudden brawl or quarrel, by killing him who assaults him.") (emphasis added).

57 Id (emphasis added):

[F]or, instead of attacking one another for injuries past or impending, men need only have recourse to the proper tribunals of justice. They cannot, therefore, legally exercise this right of preventive defence, but in sudden and violent cases; when certain and immediate suffering would be the consequence of waiting for the assistance of the law.

58 Id at *185 ("And, as the manner of the defence, so is also the time to be considered: for if the person assaulted does not fall upon the aggressor till the affray is over, or when he is running away, this is revenge, and not defence.") (emphasis added). Jeremy Horder notes that se defendendo attempted to square a homicide with the presumed "impurity of will" of one who killed:

For a defendant who only struck when his back was to the wall could be presumed to have acted without a corrupt intention. It could be presumed that he acted either 'with sorrow of heart' or 'from fear and instinctively' ... [thereby] purifying the defendant's will, tainted as it was by the deliberate character of the violence employed.

Jeremy Horder, Provocation and Responsibility 20 (Clarendon 1992). 
the threat was serious. ${ }^{59}$ If the affray was sudden, there was no time for the king and his courts, no time for the defendant to contemplate revenge, no time for the victim to put down his weapon. In other words, time had common law meaning.

\section{SURVEYING THE MEANING OF IMMINENCE}

Given that sources both outside and inside the law suggest that time is neither transparent nor without content, I sought to study the meaning of "imminence" in self-defense doctrine. My survey of twenty years of case law challenges the basic image we have of the problem of imminence in the law of self-defense.

\section{A. Assumptions Reconsidered}

When I first began this study, I assumed that a search for cases raising the issue of imminence would yield a fairly small complement of opinions, similar to the Judy Norman decision, where the defendant waited to kill her sleeping husband. My research assistants, however, soon disabused me of the notion of small numbers of cases as well as their similarity to the "waiting" fact pattern. (Ultimately, we reviewed hundreds of cases, although only a small portion turned out to be relevant to the imminence question.) I soon came to realize that the problem was with my view of "the problem." Because of the very powerful force that sleeping-man cases have on the legal imagination about self-defense-and because my findings tend to challenge this as our view of the standard "imminence" case-it is important, at the start, to ground this discussion in a different image of the problem. Admittedly, the example that follows (like Norman) may present an unusual fact pattern, but the insight it provides - that imminence has meaning - is not unusual.

Barbara Watson killed her common law husband while she was struggling with him. ${ }^{61}$ And yet the trial court rejected her claim of selfdefense on the grounds of imminence. ${ }^{62}$ Why? Not because of time.

59 See Blackstone, 4 Commentaries at *184 (cited in note 49) ("Wherefore, to excuse homicide by the plea of self-defence, it must appear that the slayer had no other possible [or at least, probable] means of escaping from his assailant.").

60 Much of this meaning has been obscured by the tendency to push temporal matters into the minds of defendants. See MPC $\$ 3.04$ (stating that "the use of force ... is justifiable when the actor believes that such force is immediately necessary"). See also Part V.B (discussing the history of Holmes's use of imminence to resolve the retreat question).

61 Commonwealth v Watson, 494 Pa 467, 431 A2d 949, 951 (1981) (relating eyewitness testimony that the victim had the defendant "around" the neck or was on top of her when she shot; trial court finds no imminent threat, a finding reversed on appeal).

62 The appellate court emphasized the centrality of imminence to the trial court's reasoning and to the case: "The central issue in this case stems from the trial court's finding that appellant's belief - that she was in imminent danger of death or great bodily harm at the time of the 
This was not the killing of a sleeping man hours after the last bout. There was a clear confrontation ${ }^{63}$ - eyewitnesses testified that the victim had jumped on top of Mrs. Watson and that he had her "around the neck." ${ }^{\text {"A }}$ The trial court based its imminence finding in part on the following: the threat was not imminent because of "the parties' relationship involving 'a long course of physical abuse."," Put another way, the threat was not imminent because the victim had been battered, that is, because Mrs. Watson should have left the relationship before the final attack. ${ }^{67}$ Imminence represented a judgment not of fact ${ }^{68}$ but

shooting-was unreasonable." Watson, $431 \mathrm{~A} 2 \mathrm{~d}$ at 951 (emphasis added).

63 Watson, 431 A2d at 951. Later cases have made quite clear that Watson was a confrontational case. See Commonwealth v Grove, 363 Pa Super 328, 526 A2d 369, 373 (1987) (citing Watson and recounting the violent confrontation that took place there).

64 Watson, $431 \mathrm{~A} 2 \mathrm{~d}$ at 951 . The appellate court reported the testimony of the defendant and a friend who was walking thirty to forty feet behind the defendant and the victim. Id. The friend, testifying for the state, reported that the victim, Mr. Black, "hit [Watson], knocked her down and jumped on top of her before the shooting." Id. The friend stated: "I know one time he got her around the neck some kind of way or another. And that's when I heard the shots, when he got her around the neck." Id. Watson testified at trial:

So we was walking, you know, up the street. And he just hauled off and grabbed me around the neck and shoulders and started choking me. And he had me down on the ground. And I was scared. And he said, "You black bitch, I should have killed you a while ago when we was at the house." And I was scared. It was me or him. I didn't know what to do, I was so scared. I was scared he was going to kill me, because he told me he was going to kill me. So that's why I shot him. I don't know how I managed to get to the gun. I was just scuffling down on the ground. It was me and him.

Id.

65 Id. The trial court also seemed to believe that the deadly response was disproportionate or overly aggressive, noting that the victim had no weapon. Id. It is well-established self-defense law, however, without regard to battered women, that a physical struggle, particularly where the parties are of unequal size, may be met with deadly force. See, for example, In the Interest of D.S., 694 S2d 565, 567 (La App 1997) ("[A] killing may be justified to prevent the infliction of great bodily harm. While weapons may be used to inflict such harm, it is often the case that an opponent who is physically large, powerful or skilled at fighting will inflict great bodily harm upon a weaker adversary.") (emphasis added). As the appellate court in Watson noted: "The fact that Mr. Black [the victim] possessed no weapon at the time of the shooting did not render appellant's belief that she was in danger any less reasonable, since it is beyond question that manual strangulation can result in serious bodily injury, if not death." $431 \mathrm{~A} 2 \mathrm{~d}$ at 952 . It is possible, of course, that the trial court conflated threat and imminence, concluding that the prior abuse undermined Mrs. Watson's claim to a reasonable expectation of serious violence. But that, again, would mean that a woman struggling on the ground had no reasonable expectation of a serious threat, precisely because she had been battered.

66 The appellate court rejected the trial court's assumptions on the question of imminence. Id at 951-52:

A woman whose husband has repeatedly subjected her to physical abuse does not, by choosing to maintain her family relationship with that husband and their children, consent to or assume the risk of further abuse. That woman faces a difficult choice: she must decide whether to endure continued abuse, or ... leave her home.

67 Lest there be any confusion, this finding cannot be rationalized as an appropriate "retreat" rule in the guise of imminence; retreat is not required, as a general rule, before the confrontation. For the difference between a pre-retreat rule (not generally required) and a retreat rule (required in some jurisdictions), see note 14 . 
of norm. ${ }^{69}$ Mrs. Watson was found guilty of manslaughter by the trial court, a sentence the appellate court reversed on the facts. ${ }^{70}$

Watson shows in a particularly dramatic way that imminence may have meaning and that its meaning may be normative and contestable. Of course, Watson is not a common type of self-defense case in many ways: battered woman cases are rare self-defense cases and rarer when reversed on appeal. Indeed, the clarity of the fight makes it unlike many self-defense cases in my survey (whether they involve male or female defendants). But Watson is not unusual in one important respect: in its challenge to our assumption that imminence should arise only in cases where the defendant "waits" for substantial periods. Imminence can, and does, find a home in cases where there appears no substantial time gap between the threat and the killing-in confrontational claims. ${ }^{\text {"1 }}$ In fact, my survey shows that imminence arises most often in confrontational rather than nonconfrontational cases. That should confound traditional expectations; indeed, it provides strong evidence that imminence may mean something more than the treatises and the law reviews tell us, more than simply "now," "upon the instant," or "at once."

68 Oddly, this version of imminence actually inverts the timing requirements, extending the time frame into the past.

69 Although it is impossible to tell, Watson may well be an example of the upward mobility of racial as well as gender norms. The trial court found that Mrs. Watson was too aggressive in circumstances that run contrary to the law of proportionality. See note 65 . The question this raises is whether stereotyped norms about the aggressiveness of African-Americans informed this finding. On this stereotype and its potential influence in self-defense cases, see Jody D. Armour, Race Ipsa Loquitur: Of Reasonable Racists, Intelligent Bayesians, and Involuntary Negrophobes, 46 Stan L Rev 781,781-85 (1994). For evidence that Mrs. Watson was African-American, see Watson, 431 A2d at 952 (recounting her testimony in which she reports that the victim [her common law husband] called her a "black bitch").

70 The court reversed for insufficient evidence. Watson, 431 A2d at 951 ("Appellant correctly asserts that there was insufficient evidence to prove beyond a reasonable doubt that the shooting of her husband was not done in self-defense.").

71 Lest Watson seem too far outside the norm, it is far from the only case in this survey in which a battered woman's claims are clearly confrontational, along the lines of the standard "fistfight" or "gun battle." See, for example, State v Sallie, 81 Ohio St 3d 673, 693 NE2d 267, 270 (1998) (relating defendant's testimony that the victim "attacked her and, as he was choking her, threatened to kill her," and she responded); Smith v State, 268 Ga 196, 486 SE2d 819, 821 (1997) (relating defendant's claim that during the fight the victim hit her and held a metal can over her head, just before she shot him); Commonwealth v Dillon, 528 Pa 417, 598 A2d 963, 965 (1991) ("[A]ppellant testified that the decedent ... grabbed her by the arm, pushed her, punched her and told her he was going to kill her just prior to her stabbing him."), affd in part, vacd in part as Commonwealth v Miller, $430 \mathrm{~Pa}$ Super 297, 634 A2d 614 (1993); Commonwealth v Stonehouse, $521 \mathrm{~Pa} 41,555$ A2d 772, 780 (1989) (relating defendant's claim that, when she shot, the defendant was pointing a gun at her).

72 See notes $34-37$ and accompanying text. 


\section{B. The Method}

My study proceeded in two steps. ${ }^{73}$ I first sought a sample of twenty years of homicide cases involving self-defense claims ${ }^{74}$ in which the term "imminence" appeared repeatedly in an trial or appellate opinion. ${ }^{75}$ This search was limited to those opinions most likely to be generated by a standard computer search. The second iteration of the study expanded this sample to achieve, as nearly as possible, a universe of cases in which imminence was stated to be an issue at trial or on appeal. ${ }^{76}$ The first iteration was limited to those cases using the term "imminence" repeatedly; the second iteration was not-a single reference to imminence in an opinion was sufficient if one could determine that imminence was considered an issue in the case. Combined, the first and second iterations yielded a dataset approximating the universe of homicide self-defense cases raising imminence as an issue and reported between 1979 and 1999.

Cases were included in the dataset only if they were "imminencerelevant." To qualify as an "imminence-relevant" case, more was required than mere discovery of the word "imminence" in the case, or a repetition of jury instructions, or standard boilerplate references to the law of self-defense. Opinions referring to imminence in a general discussion of the "three requirements of the law" of self-defense or repeated in a set of jury instructions were marked as irrelevant. In an imminence-relevant case, the concept of imminence had to appear relevant to the court's decision, the parties' arguments on appeal, or an issue at trial or on appeal. At the same time, it is important to remember that these cases typically do not discuss the meaning of imminence at any length. Very few judicial opinions deal straightforwardly with imminence as a legal question; to qualify as an issue for the purposes of my study, it was only necessary that the opinion raise, in some form, a legal question about imminence, even if it were relegated to a footnote. By "an issue," then, I do not mean the issue on appeal. An imminence-relevant case may, for example, be a case that presents itself primarily as one about evidentiary matters, or the stan-

73 A far more complete methodology and statistical analysis appears in the Appendix.

74 Included within the coverage of a "self-defense" claim were claims involving imperfect as well as perfect self-defense. Defensive force claims based on the "defense of another" were excluded because of various doctrinal differences. Also, these claims had to arise in a homicide prosecution; claims involving assaults, attempted homicide or conspiracy to commit homicide were excluded. See Appendix.

75 For a discussion of how this search was conducted, see Appendix.

76 Note that this search focused on the term "imminent," not "immediately necessary," which is the relevant statutory term in a minority of jurisdictions. On this issue, see Appendix. 
dard of review on appeal, or questions to eyewitnesses. Relevance was determined not by the holding of the case but by the legal discussion."

Opinions were first coded for their factual allegations. The question asked was whether the facts of the case, as alleged by the defendant, involved a substantial delay between attack and killing. I defined as a confrontational case any claim made by the defendant that the killing was prompted by violence that was either present or within minutes of the killing. All other claims were classified as nonconfrontational. ${ }^{78}$ Doubts about the facts were called in favor of classifying a case as nonconfrontational. ${ }^{79}$ If there was no judicial recitation of the facts, determinations about whether a claim was confrontational were based on the defendant's allegations. ${ }^{80}$ It is these allegations that would be relevant at trial and on appeal to determine the propriety of a jury instruction on self-defense. These judgments were made based on the facts as reported and, of course, ambiguity is a source of potential classification error. ${ }^{82}$ Moreover, let me emphasize at the start that

77 For example, a case that discussed imminence in the context of the admission of battered woman syndrome evidence would be an "imminence-relevant" case, as would a case that discussed imminence in the context of a jury instruction claim or an appeal on the sufficiency of evidence. Indeed, there is even a case in my dataset in which the appeal arises from the denial of witness fees. Thus, the grounds for appeal or the legal holding is not the measure of the relevancy of imminence used in this survey.

78 There are, of course, many ways in which one might draw the line between "confrontational" and "nonconfrontational" claims. It should be noted, for example, that my definition differs from that used by Professor Maguigan. See Maguigan, 140 U Pa L Rev at 391-94 (cited in note 5). Unlike Maguigan, for example, I made no attempt to determine, from the sparse facts reported in appellate opinions, whether the defendant was the "initial aggressor" who provoked the violence, or whether the victim was in a "harmless" position.

79 I resolved doubts in favor of a nonconfrontational designation because this tended to support the conventional view of the imminence problem and thus to operate against my hypothesis.

80 For example, in People $v$ Trevino, 200 Cal App 3d 874, 246 Cal Rptr 357 (1988), the appellate opinion reported that the defendant and the victim had been in a fight several hours before the victim's death. The state claimed that the victim "was asleep when [the defendant] inflicted the first stab wound," while the defendant admitted stabbing the victim but claimed the victim was awake and had again assaulted the defendant at the time of the stabbing. Id at 358. This is an unusual case. Consistent with my method to base the claim on the defendant's allegations, however, it was classified as a "confrontational" case. It is the defendant's allegations, not the state's theory, that is the basis for a judgment of a defendant's success-his ability to get to a jury.

81 A reviewing court must view the defendant's allegations in their most favorable light in determining the availability of the jury instruction she claims was omitted at trial. See, for example, Cannon v State, 615 S2d 1285, 1287 (Ala App 1993) ("In determining whether to charge the jury on self-defense, "evidence most favorable to the defendant should be considered."), quoting Byrd v State, 257 Ala 100, 57 S2d 388, 391 (1952). Of course, not all cases involving only instructional claims were cases in which the imminence discussion related to an instructional claim. Consistency, however, demanded that I take one approach to all cases; relying upon the defendant's allegations provided a standard reference point that did not require the reader to evaluate the evidence from the standpoint of a juror.

82 Appellate cases only provide limited facts; moreover, the facts are likely to be slanted in favor of the defendant. See note 81. One might argue that this will lead to a result biased in favor 
this definition of confrontation is not the same as used elsewhere. Because my study focused on the question of imminence, the idea that the victim was in an innocent position at the time of the killing does not necessarily render the case one of nonconfrontation in this survey. $^{83}$

Opinions were then coded for the meanings adopted by the author: both nonconfrontational and confrontational cases were reviewed to determine the meaning of imminence used. Cases were coded for the meaning of imminence based on statements made in the opinions themselves-how the judges explained imminence as an issue. After a pilot survey, the coding categories were based loosely on the elements of self-defense: threat, proportionality or aggression, retreat or alternatives, motive or emotion, and other. ${ }^{84}$ As one might expect, some courts' discussions of imminence reflect multiple or conflicting meanings. If the meaning could not be determined, the case was coded as "unknown." If there was more than one meaning, the case was so coded.

Coding did not proceed on the assumption that time has no objective meaning. I have no doubt that many of the judges who wrote these opinions, like the trial judge in Watson, believed that they were referring to the clock. Even if every case had been more successful in this association than Watson, the problem would still remain. We may readily assume, as the survey does, that imminence carries the meaning of time-as-clock in all of the opinions, and still ask whether imminence carries other, more problematic, meanings for the law of selfdefense.

The point of this exercise was not to provide a statistically valid claim about the relative incidence of particular arguments (immi-

of defendants, one in which the claims look more "confrontational" than they are in fact. That may be true and would be an appropriate critique if I were attempting to mirror reality. I am not, however, attempting to provide a statistical claim about whether self-defense cases are confrontational (in fact). Instead, I am arguing about the meaning of imminence. Given that most academic commentary on that issue is based on the facts rendered in appellate opinions, I justified this approach as maintaining consistency with the claims my study sought to challenge.

83 A claim, for example, that the defendant killed an attacker during a brawl when the victim was in fact restrained does not amount, for these purposes, to a nonconfrontational claim since my definition of "confrontation" depends on the question of time, as measured by the clock, not on whether the defendant was the aggressor. See, for example, State $v$ Buggs, 167 Ariz 333, 806 P2d 1381, 1382-83 (Ariz App 1990) (relating that defendant was brawling, got a weapon, and fired it; not classified as "nonconfrontational" even though the court reported that the victims of the attack were not advancing toward the defendant).

84 Although many standard formulations of self-defense omit it, jurisdictions often explicitly or implicitly emphasize the need to show the defendant's fear of, rather than malice toward, the victim. See, for example, Trevino, $246 \mathrm{Cal}$ Rptr at 360 (upholding a jury instruction requiring that the defendant acted on "fear alone," and stating that the defendant may feel "anger or other emotions" toward the victim, but they "cannot be causal factors" in the killing to be justifiable self-defense). 
nence) ${ }^{85}$ or particular kinds of claims (confrontational or not). A sample of trial and appellate opinions cannot tell us what happens at plea negotiations or at a trial that never result in a written opinion. As such, the survey carries with it enormous dangers in terms of generalizations about trial practice or real world plea negotiations. ${ }^{86}$ At the same time, this approach has one major advantage: it can provide an assessment of theoretical claims that purport to rest on a sample of judicial opinions. My claim is directed at the academic vision of imminence, as presented by casebooks, treatises, law review articles, and other sources that rely upon trial and appellate opinions. Put another way, a survey of twenty years of trial and appellate opinions is, relatively speaking, far better than the sample of one or two afforded in the standard legal treatment. That does not mean that ten cases are always better evidence than one, but simply that this argument tests present assumptions about case law. It should not be interpreted as an empirical study of self-defense practice as a whole.

A final caveat is in order. This is a survey of self-defense cases raising the question of imminence, not claims based on gender or claims by women only. For that reason, this survey should be distinguished from differently focused work, such as Holly Maguigan's important study of battered woman claims. Some time ago, Maguigan offered significant evidence that battered woman claims tend to be confrontational rather than nonconfrontational. ${ }^{87}$ My survey does not attempt to redetermine that issue (although my findings, for a limited subset of imminence-relevant cases, are consistent with her conclusions). It is, instead, a survey of the legal meaning of imminence in self-defense law, and was so constructed. Therefore, it cannot and should not be taken as a measure of the factual nature of all selfdefense cases or cases involving battered women.

\section{The Findings}

The conventional wisdom has it that imminence should arise as a legal issue only in cases where the defendant waits to kill. This study suggests that this assumption cannot be supported by judicial opin-

85 I do not know how often, for example, imminence arises in self-defense cases as a relevant issue. To assess that, I would have had to determine the number of imminence-relevant cases in proportion to the total number of self-defense cases for this period. A rough approximation to that may be obtained by comparing the number of imminence-relevant cases (233) to the total number of self-defense cases for the same period, but that would only yield a number relevant to appellate practice.

86 I have enumerated these dangers elsewhere at much greater length. See Victoria Nourse, Passion's Progress: Modern Law Reform and the Provocation Defense, 106 Yale L J 1331, 1349$50 \& \mathrm{n} 108$ (1997) (discussing such dangers in research concerning appellate cases on provocation).

87 Maguigan. 140 U Pa L Rev at 379 (cited in note 5). 
ions. The vast majority of imminence-relevant cases in my survey look like the "standard" self-defense case-a case, for example, in which the defendant alleged that he saw a weapon, ${ }^{88}$ the victim was advancing, ${ }^{89}$ or there was a fight. ${ }^{90}$ Cases where there was a substantial temporal lapse were quite rare. Eighty-four percent (196/233) of the imminence-relevant cases were coded as confrontational cases. Sixteen percent (37/233) were cases that had allegations of significant time delay. Based on standard statistical methods, we can say with significant confidence that the conventional assumption about imminence-that it arises (or should arise) only in connection with cases of long time lags - is unlikely to describe case law."

The same can be said of cases involving claims by a battered woman. Battered woman cases were relatively uncommon-less than a third of the total $(70 / 233$, or 30 percent). Nonconfrontational battered woman cases were even rarer, making up less than 10 percent of the total set of imminence-relevant cases $(21 / 233$, or 9 percent). The conventional wisdom has it that most battered woman cases fail because they fail an "objective" imminence standard: $:^{92}$ for example, the defendant kills the victim in his sleep, or there is a significant time lag between threat and killing. One would expect, then, that if one gathered all the cases involving a battered woman in which imminence was raised, that those cases would involve claims of a threat involving a significant time lag. Instead, just the opposite was found. As was true of all self-defense cases, the vast majority-almost three quarters - of battered woman cases in which imminence appears raised confrontational claims $(49 / 70$, or 70 percent $){ }^{93}$ Most battered women did not claim that they killed when the man was asleep or long after the last bout; they claimed they killed when they saw a gun, when he was lunging forward, or when they were in the middle of a fight-and yet im-

88 Cannon v State, 615 S2d 1285, 1286 (Ala App 1993) (reporting that "appellant testified that [the victim] was aiming his pistol at him and preparing to shoot as the vehicle approached"). The opinion reverses for failure to grant a self-defense instruction. In characterizing the issue, the opinion states: "Whether an accused was in imminent danger when he used deadly force against a victim ... is a question of fact for the jury." Id at 1288 (emphasis added).

89 See State $v$ Spaulding, 298 NC 149, 257 SE2d 391, 396 (1979) ("There was testimony that when the two of them went out into the yard, Simmons advanced on defendant with his hand in his pocket.").

90 See, for example, Cooper $v$ United States, 512 A2d 1002, 1003, 1006 (DC App 1986) (reporting a quarrel between two brothers in which the victim "hit [the defendant] in the head with a small radio" just prior to defendant's shooting the victim; defendant objects to jury instructions on retreat; court invokes imminence to resolve the retreat issue).

91 We can say with 95 percent confidence that the conventional hypothesis is unlikely to be true. Calculations on file with author.

$92 \quad$ See note 8.

93 Although the studies are not comparable for a variety of reasons, it is interesting to note that Holly Maguigan found that 75 percent of battered woman cases in her survey involved confrontations. See Maguigan, 140 U Pa L Rev at 397 (cited in note 5). 
minence still figured in some way in the legal understanding of the case (just as it does in cases involving male defendants). ${ }^{94}$ Again, we can say with significant confidence that the general assumption that imminence should arise only in battered woman cases that involve allegations of long delays is unlikely to describe case law."

Only if one looks solely at the very small subset of nonconfrontational cases do battered woman cases tend to appear in larger proportions. Still, even in nonconfrontational imminence cases, claims by battered women were slightly more than half of all nonconfrontational cases $(21 / 37$, or 57 percent). It turns out that nearly 40 percent of nonconfrontational claims were brought not by battered women, but instead by men and male children $\left(14 / 37\right.$, or 38 percent) ${ }^{96}$ If we eliminate claims made by male children, however, the nonconfrontational battered woman cases (twenty-one) substantially exceed the male cases (six), but both represent extraordinarily small percentages of the total universe of cases in this survey. As might be expected, battering claims - whether made by men or women-heavily dominated the small nonconfrontational universe ( $31 / 37$, or 84 percent).

In interpreting these findings, three caveats should be taken into account. First, it is important not to misconstrue my definition of confrontation. It is standard practice to conflate issues of time and threat. Perhaps there is a dispute at trial: the defendant is claiming that the victim reached for a gun but the state argues, to the contrary, that there was no gun. The factual dispute in this case is a standard one, but it is not a factual dispute about temporal matters; it is a factual dispute about the quality or seriousness of the threat faced by the defendant. If the state is right, the time does not expand-there simply is no threat.

Second, another common conflation is between the likelihood of the threat and temporal distance. It is common to use imminence as a measure of the probability of a victim's actions. For example, a defendant may claim that the victim's prior actions (shooting a gun) or prior threats ("I'll kill you") made it more probable that the victim posed a

94 See, for example, Smith $v$ State, $268 \mathrm{Ga}$ 196, 486 SE2d 819, 821 (1997) (reporting that the victim "continued to hit her and held a metal can over her head in a threatening manner," whereupon the defendant grabbed a pistol and shot the victim). Imminence arises in the context of the court's discussion of the defendant's claims about battered woman syndrome. Id at 821-26.

95 We can say with 95 percent confidence that the conventional hypothesis is unlikely to be true. Calculations on file with author.

96 Of the thirty-seven nonconfrontational cases, twenty-one were brought by a battered woman, one by a battered female child, eight by battered male children, and one by a battered man. Of the six remaining claims that did not involve battering, five defendants were male, and one was female.

97 The nonconfrontational battered woman cases amounted to $21 / 233$, or 9 percent of the total; the nonconfrontational male and male children cases represented 14/233, or 6 percent of the total. 
deadly threat at some later time. ${ }^{98}$ Again, this is a standard dispute, but one which is less about the clock than about the likelihood of the victim's threat. If time is an issue in such cases, it is an issue of the past. Presumably, a court worried that the jury might rely only on prior conduct could so instruct the jury (without focusing on imminence at all).

Finally, I am not arguing that time, as measured by the clock, is irrelevant to all of these cases. Few of the cases in the survey are as clear as Watson in showing a contemporaneous fight based on undisputed evidence. There may well be cases here in which the state believes, quite rightly, that time as measured by the clock is an issue. But if that were to occur in all of these cases, it would fail to explain the findings of this survey. For if time has meaning in these cases because the prosecutor is making an argument based on the clock, that does not explain why time is found to have other meanings-meanings other than the clock - in the vast majority of cases in my survey.

\section{Finding the Meaning of Imminence}

My survey shows that imminence is used as a proxy for other selfdefense factors - in some cases openly fault-based factors - in both confrontational and nonconfrontational cases. When the court hears an argument about jury instructions on the question of imminent threat, courts often are considering the severity of the threat: was the threat imminent in the sense of whether it was serious or probable to arise $?^{99}$ In other cases, they are considering the necessity of the response or the possibility of retreat: was the threat imminent in the sense that there were no alternatives to a deadly response? ${ }^{100}$ In still others, the court is concerned with the defendant's motive or emotions: was the threat imminent in the sense that the defendant was act-

98 See, for example, State v Hundley, 236 Kan 461, 693 P2d 475 (1985).

99 See, for example, McCracken v State, 914 P2d 893, 895, 898 (Alaska App 1996) (describing situation in which man in wheelchair killed caretaker after caretaker threatened to knock him out of the wheelchair and caretaker "leaned forward as if to stand up"; at trial the "disputed issues" involved whether defendant believed he was responding to an "imminent" threat); People v Martinez, 206 Ill App 3d 813, 564 NE2d 1271, 1279-80 (1990) (suggesting that the defendant used disproportionate force to repel an attack of the victim, and then concluding that prior threats were "insufficient evidence to establish a reasonable belief that [defendant] was in danger of imminent deadly or great bodily harm").

100 See, for example, State $v$ Williford, 49 Ohio St 3d 247, 551 NE2d 1279, 1282-83 (1990) (noting state's claim that the defendant did not prove imminence and emphasizes the fact that the jury appears to have found the defendant had alternate means to escape besides the use of force); Cooper v United States, 512 A2d 1002, 1004 (DC App 1986) (concluding that the jury could consider whether the defendant could retreat in determining whether he was " actually or apparently in imminent danger"'), quoting Gillis v United States, 400 A2d 311, 313 (DC App 1979). 
ing out of fear rather than malice ${ }^{101}$ Finally, imminence also appears as a question of aggression or provocation: was the threat imminent in the sense that the victim (rather than the defendant) was the principal aggressor? ${ }^{102}$

\section{The confrontational cases.}

By far the most common way in which time carries meaning in this survey is through the severity of the victim's threat. Indeed, the vast majority of confrontational cases were ones in which imminence appeared as a measure of the severity of threat or proportionality of violence (140/196, or 71 percent). Typical of such cases are ones in which the court concludes that there was no imminent threat because the victim was unarmed, ${ }^{103}$ was not in a physical position to pose a threat, ${ }^{104}$ or was turning away or had gone. ${ }^{105}$ In one sense, this is not

101 See, for example, In re Christian S., 13 Cal Rptr 2d 232, 235 (Cal App 1992) (reporting that the trial court "focused on the substantial interval during which Christian aimed at Elliott [the victim] before firing [in an ongoing confrontation], concluding he [the defendant] had sufficient time to carefully consider what he was doing"), superseded on other grounds, 7 Cal 4th 768 , 872 P2d 574 (1994); State v Jackson, 22 Ohio St 3d 281, 490 NE2d 893, 897 (1986) (concluding that the jury believed testimony that showed the defendant "did not believe he was in imminent danger" but instead that "appellant acted out of jealous anger toward the victim rather than out of fear for his life").

102 See, for example, Ellis v State, 708 S2d 884, 888 (Miss 1998):

Even assuming that Ellis did in fact see Banks [the victim] flash a gun a few minutes earlier, Ellis had clearly made himself the aggressor by continuing to chase down a victim running for his life.... Under the facts of the present case, there is no reasonable probability that a jury would have concluded that Ellis was in imminent danger.

103 See, for example, State $v$ Spinks, 1998 Wis App LEXIS 306, *13-14 (holding defendant "could not have reasonably believed ... that he was in danger of imminent death or great bodily harm. ... There was no evidence that [the victim] had a weapon or in any way posed a serious threat to [the defendant].") (emphasis added); State v Gayden, 259 Kan 69, 910 P2d 826, 836 (1996) (finding no evidence of imminent threat in a barroom brawl case because." [t]here was no evidence that [the victim] was armed or displayed a weapon," only that he struck "one blow against defendant with his hand") (emphasis added); People v Hoover, 250 Ill App 3d 338, 620 NE2d 1152, 1161 (1993) ("Although defendant claimed that she saw a shiny object on the floor of the passenger side of the car, she admitted that she did not see Barker [the victim] with a weapon. Therefore, defendant cannot claim that she was in imminent fear.") (emphasis added).

104 See, for example, State v LeFaber, 77 Wash App 766, 893 P2d 1140, 1146 (1995) (Schultheis concurring in part, dissenting in part) (stating that "the jury could have found that Mr. LeFaber reasonably believed Mr. Stephens [the victim] intended great personal injury, but that in fact there was no imminent danger because Mr. Stephens was unarmed, still outside the house and the police were presumably en route") (emphasis added), revd, 128 Wash 2d 896, 913 P2d 369 (1996); State $v$ Blackman, 875 SW2d 122, 133 (Mo App 1994) (stating that the defendant "possessed both his own firearm and the victim's firearm and the victim had been shot in the chest and in the hand. He [the defendant] was no longer in imminent danger."); State $v$ Correa, 437 Pa Super 1, 648 A2d 1199, 1202 (1994) (noting that "Correa could not have believed that he was in imminent danger from behind a locked door").

105 See, for example, People v Horton, 233 Ill App 3d 22, 598 NE2d 452, 455 (1992) ("The defendant, however, was not in imminent danger of death or great bodily harm ... because Sullivan [who provoked the fight, although he was not the victim] had already left the premises."); 
surprising. The connection between imminence and threat is quite common in everyday discourse. Indeed, it seems difficult to speak of imminence without the notion of danger or threat or harm. On another level, however, this should be surprising since imminence seems to serve little doctrinal purpose here. If these cases do not involve allegations of long waits between threat and killing, but of spontaneous fights and confrontations, then the question raised is whether imminence is simply superfluous.

If imminence operated only as a proxy for the threat's severity, we might conclude that the terms "imminence" and "threat" were inevitably conjoined, reinforcing each other, and that there was an easy remedy in more economical prose. But many confrontational cases show that other meanings are at work alone or in addition to the severity of threat $\left(120 / 196\right.$, or 61 percent). ${ }^{106}$ Imminence may be constructed in the image of the defendant's motives, emotions $(29 / 196$, or 15 percent), or perceptions (63/196, or 32 percent), the defendant's ability to exercise alternatives (28/196, or 14 percent), or the defendant's responsibility for the confrontation (aggression or provocation) $\left(29 / 196\right.$, or 15 percent). ${ }^{107}$

To see how imminence might operate as a proxy for these kinds of issues, consider In re Christian $S .{ }^{108}$ a case involving a juvenile who was being taunted by a skinhead named Elliott. ${ }^{109}$ There was no dispute that the defendant, Christian, had killed Elliott after an extended set of confrontations on a beach, each time pointing the gun but then running away. The question was whether the presence of malice aforethought had been sufficiently established in the trial court. ${ }^{110}$ To the trial judge, time implied malice. It was the "substantial interval during which Christian aimed at Elliott before firing" that convinced the court of Christian's malice: the defendant "had sufficient time to carefully consider what he was doing."

State v McCarter, 820 SW2d 587, 590 (Mo App 1991) ("[The eyewitness's] testimony would not support a finding of imminent danger. ... Rather, the testimony shows no visible signs [the victim] possessed a weapon; [the victim's] direction of movement was away from defendant; and that defendant started to leave and shot as [the victim] headed for the house.").

106 Cases involving threats alone constituted $76 / 196$, or 39 percent, of the total, leaving most cases to have some meaning other than threat (120/196, or 61 percent).

107 If there is a good deal of evidence that time-talk is really a surrogate for questions of fault, it is unsurprising to see not only cases in which imminence stands in for other self-defense factors but also cases in which time disappears as a factor when fault is clear. See, for example, Hart v State, 637 S2d 1329, 1336-38 (Miss 1994) (stating that in a case in which the defendant clearly pursued the victim and provoked the confrontation, the defendant cannot claim selfdefense no matter how imminent the ultimate threat).

10820 Cal App 4th 1210, 13 Cal Rptr 2d 232 (1992), superseded on other grounds, 7 Cal 4th

768, 30 Cal Rptr 2d 33, 872 P2d 574 (1994).

10913 Cal Rptr 2d at 233.

110 Id at 235-36.

111 Id at 235 . 
terpreted the meaning of time rather differently, finding lack of malice." "Elliott's repeated threats and his continued pursuit of Christian in the face of his request to be left alone confirmed the immediacy of that risk." 113

Notice what has happened here: the clock did not change, but its meaning did. There was no dispute between the trial and appellate courts about the actual temporal lapse between the threat and the shooting. To the trial court, time signified Christian's malice, his motive or emotion. To the appellate court, it signified a different set of emotions and a lack of motive-Christian's fear of Elliott's taunts. ${ }^{114}$ For both courts, imminence served as a proxy for emotion and motive, fear or malice.

If the motive/emotion cases make clear that imminence can absorb meanings that seem far more "interior" and "personal"-even subjective - than the clock, cases linking imminence and alternatives show how time may cast more than one meaningful shadow. In these cases, a finding of no imminence was a way of saying that the defendant did not really "need" to kill, in that there were easily available choices other than deadly violence. ${ }^{116}$ The defendant might have left through the kitchen door, he might have simply "locked" his home,

112 Id at 238.

113 Id.

114 In re Christian $S$. is not alone in its equation of imminence with motive and emotion. See, for example, Commonwealth v Pike, 428 Mass 393, 701 NE2d 951, 956 (1998) ("This testimony indicates that the defendant threw the radio at Holmes [the victim] out of a feeling of anger or revenge resulting from the first stage of the altercation. It does not support at all the contention that he acted out of fear of 'imminent danger of death." "), quoting Commonwealth $v$ Barros, 425 Mass 572, 682 NE2d 849, 853 (1997); State v Jackson, 22 Ohio St 3d 281, 490 NE2d 893, 897 (1986) (concluding that the jury believed the state's witnesses when they said that the defendant did not believe in an imminent threat because "testimony showed that appellant acted out of jealous anger toward the victim rather than out of fear for his life"); People v Trevino, 200 Cal App 3d 874, 246 Cal Rptr 357, 360 (1988):

The party killing is not precluded from feeling anger or other emotions save and except fear; however, those other emotions cannot be causal factors in his decision to use deadly force... . But if the only causation of the killing was the reasonable fear that there was imminent danger ... then the use of deadly force in self-defense is proper regardless of what other emotions the party who kills may have been feeling but not acting upon.

115 The trial court emphasized the interval of time before the shooting to support a finding of malice by equating time with deliberation. $13 \mathrm{Cal}$ Rptr $2 \mathrm{~d}$ at 235 . The appellate court concluded that the threat did not have to be imminent to negate malice; all that was necessary was a finding that the defendant had a sincere (even if unreasonable) fear of an imminent threat. Like the trial court, then, the appellate court transformed time into a question of mind (a belief in an imminent threat) and emotion (fear). Id at 238.

116 Although I believe the equation of retreat and imminence should be more controversial given that the retreat issue has caused great division in the law of self-defense, it is hardly the invention of my imagination. It can be found in Black's Law Dictionary 676 (West 5th ed 1979) (defining "imminent danger" as being "such as cannot be guarded against by calling for the assistance of others or the protection of the law") (emphasis added). 
waited for the police, or avoided the confrontation after it began. ${ }^{117}$ As one judge explained, "[t]he existence of alternatives to homicide ... goes to the reasonableness of the defendant's belief that he was in imminent danger of death or great bodily harm."

Indeed, in some states, the link between imminence and alternatives has been acknowledged openly. Some courts, for example, have rejected jury instructions that specifically equate time and alternatives on the ground that this re-creates a rule of retreat. In Craig $v$ State, where the killing resulted from a physical fight, the court rejected, as inappropriate, a jury instruction defining an imminent threat as one "so urgent that there is no reasonable mode of escape except to take life" on the theory that there was no rule requiring retreat in that jurisdiction. ${ }^{120}$ Other jurisdictions appear to have taken the opposite view. In New Jersey and Ohio, for example, courts define imminence as requiring a judgment of appropriate alternatives, as a danger "that could only be forestalled or escaped by a resort to the use of force." ${ }^{121}$ In State $v$ Kelly, ${ }^{122}$ for example, the New Jersey Supreme Court made clear that the imminence rule requires that an actor "who reasonably fears that her life will soon be endangered ... leave the danger zone." ${ }^{123}$ Whether imminence is seen as reinforcing an existing retreat requirement or as creating a new one, this survey makes clear that such doctrinal links are not isolated cases. ${ }^{124}$

117 For examples of cases in which courts explicitly equate imminence and alternatives, see State v Renner, 1994 Tenn Crim App LEXIS 581, *18-21 (affirming prosecution's right to question defendant on whether "he could have left through the kitchen door and avoided confrontation" even though there was no duty to retreat because "leaving through the kitchen door" was relevant to the credibility of defendant's fear and thus, to the "imminen [ce of] danger of death or serious bodily injury") (emphasis added); State v Williford, 1988 Ohio App LEXIS 1906, *24-25 (rejecting the state's argument-that defendant was not entitled to a self-defense instruction because the danger was not imminent and "appellant had alternative means of escape, presumably to lock his front door behind him"-even though acknowledging defendant was not required to retreat); State $v$ Williams, 470 S2d 617,620 (La Ct App 1985) ("The evidence shows that the defendant did not believe himself in imminent danger of receiving great bodily harm. He could easily have returned to his own house, which was next door, and avoided any confrontation with the victim."), revd, 483 S2d 999 (La 1986) (concluding that the defendant did act in self-defense).

118 Patterson v State, 682 P2d 1049, 1053-54 (Wyo 1984) (Rose concurring) (affirming lower court's refusal to provide a jury instruction on self-defense).

119660 S2d 1298 (Miss 1995).

120 Id at $1299-1300$.

121 State $v$ Eng, 1994 Ohio App LEXIS 4655, *6.

12297 NJ 178, 478 A2d 364 (1984).

123 Id at $385 \mathrm{n} 23$.

124 See Bechtel v State, 1992 Okla Crim 55, 840 P2d 1, 12 (1992) (stating that there is a "presumption in imminence that the defender may find an alternative to the use of deadly force," and therefore the court found it "necessary to address the duty to retreat, which duty is implicit in said presumption") (emphasis added). Similarly, in the District of Columbia, imminence is part of the "retreat" calculation. In Cooper v United States, 512 A2d 1002 (DC App 1986), the defendant alleged that he killed his brother after an altercation in which the brother had hit him over the head with a radio; the defendant objected to the failure to give a favorable no-retreat instruc- 


\section{Battered woman confrontational cases.}

If time carries multiple meanings in self-defense cases in general, the question becomes whether this also occurs in the smaller subset of cases involving a battered woman defendant. My survey shows that imminence can be found operating as a surrogate for motive, alternative, and aggression in battered woman confrontational cases, as it does in cases not involving battering. Many of the battered woman cases in this survey involved what I will term "weak" prompting threats in a violent context-a claim that the defendant believed the victim was moving toward a gun, that the victim had his "hands raised" as if in attack, or that the victim was moving suspiciously or threateningly. ${ }^{125}$ In this sense, these cases look similar to many standard self-defense claims, where the male defendant hears a "noise like branches shaking," ing for a weapon," ${ }^{127}$ or believes that "there was a shiny object." ${ }^{128}$ Like their male defendant counterparts, the battered woman cases often include arguments in which imminence serves as a proxy for the seriousness of the threat, the proportionality of the defendant's response, or the available alternatives.

tion. Id at 1002. The court refused to decide the retreat question, preferring a "middle ground" in which alternatives were to be considered under the rubric of "imminence." Id at 1006. There are individual cases, and judges, in other jurisdictions that appear to make the same connection. For example:

The jury must evaluate such perceptions in context... Therefore, if they would "induce a well founded belief ..." that immediate defense against the impending danger was the only means of escape from great bodily injury or death, the law of self-defense justifies use of whatever force is necessary to "avert the threatened peril."

People v Humphrey, 13 Cal 4th 1073, 921 P2d 1, 14 (1996) (Brown concurring) (emphasis added), quoting People v Scoggins, 37 Cal 676, 684 (1869).

125 See, for example, State $v$ Hodges, 239 Kan 63, 716 P2d 563, 564-65 (1986) (reporting that, after beating, defendant killed upon being threatened), disapproved in part, State $v$ Stewart, 243 Kan 639, 763 P2d 572 (1988); State v Osbey, 238 Kan 280, 710 P2d 676, 678 (1985) (reporting that defendant killed when victim reached behind record albums; defendant claimed she believed he was reaching for a weapon). Of course, there were cases involving stronger threats. See note 71 (describing such cases).

126 State $v$ Negrin, 37 Wash App 516, 681 P2d 1287, 1290 (1984) (describing claim in which defendant shoots into woods because he finds evidence of a burglary and hears rustling in the bushes and a loud stomping; a self-defense instruction was given at trial).

127 State v Bellino, 31 Conn App 385, 625 A2d 1381, 1385 (1993) (describing instructions and indicating that a self-defense instruction was given at trial).

128 State v Fuller, 297 SC 440, 377 SE2d 328, 331 (1989) (reversing for failure to instruct that the defendant could have acted in self-defense based in part on the fact that he saw the victims "open the trunk of their car and also thought he saw a shiny object in [the victim's] hand"). See also People v Spencer, 51 Cal App 4th 1208, 59 Cal Rptr 2d 627, 632 (1996) (describing claim that the defendant shot when the victim "reach[ed] down to the floorboard of the car," believing the victim "was pulling out a gun"). 
Consider State $v$ Hundley. ${ }^{129}$ There, the victim had fled to a hotel because of battering by her husband. ${ }^{130}$ Earlier in the day, he had threatened to kill her. That night, he broke into her hotel room and proceeded to brutalize and rape her. ${ }^{131}$ After it was over, he pounded a beer bottle (a source of injury in the past) on the table and ordered her to get him cigarettes. ${ }^{132}$ She felt threatened and reached for a gun she had brought for protection. "Carl laughed tauntingly and said, 'You are dead, bitch, now!' ... [and] reached for the beer bottle." ${ }^{133}$ She shut her eyes and fired. ${ }^{134}$ The issue on appeal was whether the trial court had properly instructed the jury in requiring an "immediate" rather than an "imminent" harm."

Interestingly enough, of course, there really was no issue of imminence in this case if by imminence we mean a significant time gap between the threat and the killing. No sleeping husband was present in Hundley. At least temporally, Hundley's allegations are very far from Judy Norman's. If Hundley's allegations are believed, ${ }^{136}$ she was presented with a confrontational situation much like those of the standard barroom brawl in which there is a fight or a threat and the victim is "reaching for a beer bottle" ${ }^{137}$ or pool cue, gives a hostile look

129236 Kan 461, 693 P2d 475 (1985).

130 The past history of violence was not disputed by the appellate court, which recounted that the defendant's husband

had knocked out several of her teeth, broken her nose at least five times, and threatened to cut her eyeballs out and her head off. Carl [the victim] had kicked Betty [the defendant] down the stairs on numerous occasions and had repeatedly broken her ribs. Mrs. Hundley [the defendant] suffered from diabetes and, as part of his abuse, Carl prevented Betty from taking her required dosage of insulin ... [n] eedless to say, Betty Hundley went into diabetic comas on those occasions.

Id at $475-76$.

131 Id at 476. State $v$ Stewart, 243 Kan 639, 763 P2d 572, 578 (1988) (summarizing the Hundley facts):

Several weeks prior to the shooting, Betty [the defendant] had moved to a motel. Carl [the victim] continued to harass her and threaten her life. On the day of the shooting, Carl threatened to kill her. That night he forcibly broke into Betty's motel room, beat and choked her, painfully shaved her pubic hair, and forced her to have intercourse with him.

132 Hundley, $693 \mathrm{P} 2 \mathrm{~d}$ at 476.

133 Id.

134 Id.

135 See id at $477-78$.

136 See id at 477 ("None of appellant's evidence was controverted. The State's case was dependent upon the jury believing from appellant's evidence there was no immediate threat to appellant.").

137 See State v Hill, 242 Kan 68, 744 P2d 1228, 1232, 1236 (1987) (reversing for failure to instruct on self-defense in a case where an eyewitness claimed that the victim "raised her hand like she had [an unknown object] in it with which she was trying to hit [the defendant]"); State $v$ Kelly, 131 Kan 357, 291 P 945, 946-47 (1930) (affirming the self-defense instruction given in a case where the defendant said the victim gave him a "mean look" and withdrew his hand from his pocket). These are cases in which a weak threat becomes a good deal stronger in the context of an ongoing fight or threats of violence. 
and reaches into his pocket, or seems to have a "shiny object." ${ }^{138}$ Indeed, it is not surprising that ultimately the appellate court in Hundley resolved the threat issue in the defendant's favor, concluding that, in the context of their relationship, Carl's threat ("you are dead") "was no less life-threatening with him sitting in the motel room tauntingly playing with his beer bottle than if he were advancing toward her."139 As the Kansas Supreme Court later described the case, the defendant was "clearly threatened in the moments prior to the shooting[ ].",

The important point to see here, for our purposes, is that despite the appellate court's extended discussion of the difference between the terms "immediate" and "imminent," the questions in Hundley were not really about time. Instead, imminence served as a proxy for the severity of the threat and the opportunity for withdrawalquestions, in short, about proportionality, threat, and retreat. For example, the state's answer to the defendant's claim was not about timing as much as it was about the banging of a beer bottle and whether that was a severe threat. ${ }^{142}$ Similarly, the dissenting judge equated time with alternatives, concluding that the majority was incorrect because Hundley had an opportunity to retreat. If only she had complied with her attacker's demands and left to get the cigarettes, the dissenter argued, Hundley would have had a five-minute head start."

If the battered woman confrontational cases were similar to the rest of the population in the sense that imminence had meaning, these cases also diverged in some respects. Often, the argument on appeal was evidentiary: whether the trial court properly refused to permit battered woman syndrome testimony. ${ }^{1+4}$ On appeal, the court would

138 See, for example, Spencer, 59 Cal Rptr $2 \mathrm{~d}$ at 632 (describing claim that the defendant shot when the victim "reach[ed] down to the floorboard of the car" and the defendant believed the victim "was pulling out a gun"); Fuller, 377 SE2d at 331. See also note 128.

139 Hundley, 693 P2d at 479.

140 Stewart, $763 \mathrm{P} 2 \mathrm{~d}$ at 577.

141 Hundley, 693 P2d at 478-81.

142 Id at 477. At trial, the state argued that there was "no immediate threat." Id. Since there was no time lag between the death threat/banging of the beer bottle and the shot, the argument had to be one about the severity of the threat. On appeal, the state claimed that Hundley was seeking to apply a subjective standard, implying that the death threat/beer bottle was not an objectively sufficient threat under the circumstances. Id at 478 .

143 Hundley, $693 \mathrm{P} 2 \mathrm{~d}$ at 481 (McFarland dissenting) (concluding that the harm to the defendant could not have been imminent because of available alternatives and therefore the difference between imminent and immediate was harmless in this case). See id at 480 , quoting Black's Law Dictionary 675-76 (5th ed 1979) for the proposition that "imminent danger" means "such as must be instantly met, such as cannot be guarded against by calling for the assistance of others or the protection of the law."

144 See, for example, State v Koss, 49 Ohio St 3d 213, 551 NE2d 970, 974-75 (1990) (overruling prior Supreme Court of Ohio precedent that prohibited the use of battered woman syndrome evidence to support self-defense as an affirmative defense). 
discuss imminence but would do so in the context of the meaning of syndrome evidence. Almost half of the battered woman confrontational cases raised imminence in the context of a discussion of battered woman syndrome (24/49, or 49 percent). Indeed, it was a standard appellate account in which battered woman syndrome was considered relevant because of imminence - on the theory that a battered woman has a different "perception" of the imminence of serious violence. ${ }^{145}$

More significantly, the battered woman cases diverged from the general population in the degree to which they showed courts equating imminence with alternative courses of action: the defendant could have called the police, ${ }^{146}$ had the victim arrested, ${ }^{147}$ or taken advantage of a five-minute head start. ${ }^{148}$ There was a significantly greater percentage of battered woman confrontational cases in which imminence appears as a surrogate for alternatives ( 47 percent) than other confrontational cases ( 20 percent).$^{149}$ At least some of these cases seemed to equate imminence directly with retreat. When they asked the question of imminence, courts asked not about time but whether killing "was the only means of escape from great bodily injury or death."

145 See id at 973 ("Expert testimony regarding the battered woman syndrome can be admitted to help the jury not only to understand the battered woman syndrome but also to determine whether the defendant had reasonable grounds for an honest belief that she was in imminent danger when considering the issue of self-defense."); Smith $v$ State, 268 Ga 196, 486 SE2d 819, 821-26 (1997) (battered woman syndrome as relevant to imminence); Bechtel v Oklahoma, 1992 Okla Crim 55, 840 P2d 1, 12 (same); Commonwealth v Dillon, 528 Pa 417, 598 A2d 963, 966-67 (1991) (Nix concurring) (same), affd in part, vacd in part as Commonwealth v Miller, $430 \mathrm{~Pa}$ Super 297,634 A2d 614 (1993). Occasionally, a court would note the disconnect between a claim of "imminence" and a confrontational situation and, on that basis, rule against the battered woman defendant. See, for example, State v Sallie, 81 Ohio St 3d 673, 693 NE2d 267, 269-71 (1998) (denial of ineffective assistance claim for failing to introduce battered woman syndrome testimony on the theory that defendant's claim was "confrontational" and therefore the evidence would have been inadmissible as "unnecessary").

146 See, for example, State v Moore, 568 S2d 612,617 (La App 1990) ("[The defendant] may have been in some danger, but it was not imminent danger. Although the telephone was not in perfect working order, it was still functional and could have been used to call for assistance.").

147 Commonwealth v Stonehouse, 358 Pa Super 270, 517 A2d 540, 544 (1986) ("At the time he was gunned down the victim did not present a threat of imminent danger of death or great bodily harm." Given the parties' relationship, physical separation at the time of the shooting, and status as police officers, "[a]ppellant had ample time and opportunity to have the victim arrested."), revd on other grounds, $521 \mathrm{~Pa} 41,555$ A2d 772 (1989).

148 Hundley, 236 Kan 461, 693 P2d at 480-81 (1985) (McFarland dissenting) (arguing that defendant could have had a "five-minute head start" if she had "failed to return with the cigarettes" as the victim had demanded).

149 We can say with 95 percent confidence that the contrary hypothesis is unlikely to be true. Calculations on file with author. There may be a number of reasons for this finding: it may be, for example, that alternatives are arising more in these cases because battered woman syndrome evidence is more likely to be considered, and one of the "purposes" of such evidence is to rebut the notion that "she could have left." For an explanation, see note 223 and accompanying text.

150 People v Humphrey, 13 Cal 4th 1073, 921 P2d 1,14 (1996) (Brown concurring) (emphasis 
Other courts equated imminence and alternatives via battered woman syndrome testimony - the syndrome attempts to rebut the notion that "she should have left" and the syndrome was viewed as relevant to the legal question of "imminence."

\section{The nonconfrontational cases.}

This leaves us with a small minority of nonconfrontational cases (37/233, or 16 percent) ${ }^{152}$ Interestingly enough, even though clock time is an issue in these cases, courts did quite a bit more than simply refer to the temporal. Indeed, in almost all of these cases $(28 / 37$, or 76 percent), ${ }^{153}$ courts made arguments similar to the ones we have seen above in the confrontational cases, arguments based on other selfdefense factors. They claimed not only that the time was too long, or that the attack was preemptive, but also that the defendant had time to premeditate or to choose lawful alternatives, and that there was no real threat or a disproportionate response. The nonconfrontational cases, then, only serve to confirm what the confrontational cases tell us: that imminence has a tendency to serve as a proxy, a convenient

added), quoting People v Scoggins, $37 \mathrm{Cal}$ 676, 684 (1869). See also cases cited in notes 146-48. Occasionally, a defendant's attempt to take reasonable alternatives to avoid the violence will be used to support a finding of imminent threat. See, for example, State v Lynch, 436 S2d 567, 569 (La 1983) (noting with favor, in concluding that the defendant was faced by an imminent threat, that the defendant "was trying to retreat and asked [the victim] to leave her alone") (emphasis added).

151 See, for example, Bonner v State, 740 S2d 439, 440 (Ala Crim App 1998) (noting that battered woman syndrome evidence may be admitted to "dispel the ordinary lay person's perception that a woman in a battering relationship is free to leave at any time"), quoting State v Koss, 49 Ohio St 3d 213, 551 NE2d 970, 973 (1990); State v Williams, 787 SW2d 308, 313 (Mo App 1990) (stating that "[t]he [battered woman syndrome] evidence rejected was necessary for a jury to understand the defendant's perceptions of her situation, particularly her feelings that no escape was possible, and her resultant conclusion that killing [the victim] was an act of self-defense"); Ibn-Tamas v United States, 407 A2d 626,633-34 (DC App 1979) (emphasis added):

[T] he government implied to the jury that the logical reaction of a woman who was truly frightened by her husband (let alone regularly brutalized by him) would have been to call the police from time to time or to leave him. In an effort to rebut this line of attack by the government, the defense proffered Dr. Walker's [expert] testimony to ... [among other things] provide a basis from which the jury could understand why [the defendant] perceived herself in imminent danger at the time of the shooting.

152 For examples of such cases, see generally Ha v State, 892 P2d 184 (Alaska App 1995) (holding that reasonable fear that the victim would someday kill the defendant did not constitute fear of "imminent" harm for purpose of the defendant's self-defense claim); People $v$ Aris, 215 Cal App 3d 1178, 264 Cal Rptr 167 (1989) (holding no self-defense where wife killed husband in his sleep), overruled in part by People v Humphrey, 13 Cal 4th 1073, 921 P2d 1 (1996); State v Stewart, 243 Kan 639, 763 P2d 572 (1988) (holding homicide not justified as self-defense by battered wife where no evidence of deadly threat or imminent danger); Jahnke v State, 682 P2d 991 (Wyo 1984) (upholding voluntary manslaughter conviction of son who killed father because son premeditatedly attacked father without immediate provocation).

153 Even if we eliminate those cases in which threat alone is at issue, a majority of nonconfrontational cases still use imminence as a proxy for other factors $(21 / 37$, or 57 percent). 
one-word symbol for a variety of legal arguments, arguments that seek to adjudicate the relative responsibility of the parties for the conflict (and, as we will see later, their relationship to the state). This occurred in cases of male defendants ${ }^{154}$ and female ones as well as in cases involving battering ${ }^{155}$ and those that did not. ${ }^{156}$

The nonconfrontational cases, like their confrontational counterparts, suggest important caveats for the traditional objectivist position on imminence. Courts often say that imminence means that the violence must be "now," "at the instant," or "presently," but when pushed to explain their results these courts often seem to refer to factors bearing on the relative responsibility of the parties for the violence. The defendant in $\mathrm{Ha} v$ State ${ }^{157}$ had twelve hours between the fight and killing, time measured not only in hours and minutes, but in the time to change his course and to summon the constable. When he did not, his act was deemed one of revenge. ${ }^{158}$ Similarly, the defendant in $\mathrm{Peo}$ ple $v$ Aris,${ }^{159}$ who killed her husband in his sleep, had time to leave her husband and move in with her aunt; ${ }^{160}$ and for all we know, he might have changed his mind about beating her again. ${ }^{161}$ Of course, once expressed this way, we can begin to see that time has proceeded very far from the clock. We only get to these questions, however, if we consider the possibility that, even in cases where time has an objective referent, it may also carry other meanings.

154 See, for example, $\mathrm{Ha}, 892 \mathrm{P} 2 \mathrm{~d}$ at 195 (equating time with the time to seek legal redress: "The evidence at Ha's trial shows that $\mathrm{Ha}$ [the defendant] had ample opportunity to inform others of his conflict with Buu [the victim] and to seek their assistance.") (emphasis added). See also id, equating a twelve-hour time gap between fight and killing with emotion (lack of fear).

155 Aris, 264 Cal Rptr at 173 (equating time with seriousness of threat: an immediate, rather than a prior threat, is required "because it may be that the party making the threat has relented or abandoned his purpose, or his courage may have failed, or the threat may have been only idle gasconde [sic], made without any purpose to execute it"); id (equating time with alternatives: an imminent threat is one "so urgent as to afford no reasonable mode of escape other than by killing"), quoting People v Fowler, 178 Cal 657, 174 P 892, 898 (1918). The Aris court further argued:

The law of self-defense, whether perfect or imperfect, does not provide an alternative means of resolving the battered woman's problem. For resolution of that problem, a battered woman must look to other means provided by her family, friends, and society in general such as restraining orders, shelters, and criminal prosecution of the batterer.

264 Cal Rptr at 174 (emphasis added).

156 See generally $\mathrm{Ha}, 892 \mathrm{P} 2 \mathrm{~d} 184$.

157892 P2d 184 (Alaska App 1995).

158 See id at 195 (stating that the defendant had ample opportunity to seek legal redress); id at 196 (explaining that the defendant had no reasonable fear of imminent danger when he "hunted Buu [the victim] through the streets of Dillingham and then shot him from behind").

159215 Cal App 3d 1178, 264 Cal Rptr 167 (1989), overruled in part by People v Humphrey, 13 Cal 4th 1073, 921 P2d 1 (1996).

160264 Cal Rptr at 174 ("The law cannot allow her to shoot her husband instead of, as was the case here, inconveniencing her out-of-state aunt by moving in with her.").

161 See note 155. 


\section{IMPLICATIONS FOR THE DOCTRINE AND THEORY OF SELF-DEFENSE}

If my survey is right, then it should no longer be sufficient to wave one's hand at the clock and insist that the justificatory principles of self-defense depend upon an "objective" imminence requirement without, at the same time, explaining precisely what the imminence requirement means. Nor should it be sufficient to conclude that the problem of imminence is relegated to the relatively rare battered woman case. Instead, it should be seen for what it is-a problem that affects all self-defense cases. My argument is not that time has no objective meaning in the law or in life; it is that the assertion of its objectivity is too often incomplete. By studying the meaning of imminence, we may shed light not only on the problems of this particular doctrinal rule, but more generally on the debate about subjectivity and objectivity within the criminal law.

In this Part, I consider some of the implications of my findings for the doctrine and theory of self-defense. In Part III.A, I argue that imminence may take back with one hand what the law provides with the other hand in other self-defense rules (particularly, the retreat doctrine). In Part III.B, I urge that these contradictions reflect conflicting models of necessity. Finally, in Part III.C, I argue that this is not explained or resolved by the ever-present debate about excuse and justification in the law of self-defense.

\section{A. Doctrinal Disarray}

If my survey is right, the law is routinely (if not invariably) imposing a rule it considers to be about "time" in cases where "time" may not matter. When a man is involved in a brawl or suspects an attacker is in the bushes, or sees a flash of a gun, and kills, time (at least as measured by the clock) is not really the issue. ${ }^{162}$ Even if courts are simply using the term "imminence" loosely, there should be more concern about this odd usage. There are obvious costs of misdirection-risks that the law's apparent meaning is not its real one. Moreover, there are risks of "double-counting," or "intensifying," accomplished by a rule of imminence that simply repeats other factors (if imminent threat simply means a grave threat, what do we gain by saying "grave threat" twice?). ${ }^{163}$ But these costs are not simply ones of indeterminacy and redundancy but also of potential inconsistency. If imminence

162 Instead, the question is one of threat: was the flash in the woods a serious threat, serious enough to provoke deadly violence, either as a matter of a reasonable perception in the situation or without regard to the defendant's position?

163 Of course, if this were a measure of doctrinal tests, which are notoriously repetitive, then that would not be much of a critique. 
serves as a proxy for other self-defense factors-questions of motive and emotion and retreat-then scholars of self-defense should be worried not only that imminence is sloppy but also that, as applied, imminence invites doctrinal confusion. Indeed, they should be worried that, despite the conventional wisdom that the elements of selfdefense are well-established and coherent, in fact the law of imminence reflects deep conflicts in the law of self-defense.

This becomes particularly clear when one compares rules on imminence with those on retreat (although potential inconsistencies are not limited to retreat rules). For approximately 150 years, the law of the United States has been in some conflict about retreat. ${ }^{1.4}$ The majority view is that retreat is not required, ${ }^{165}$ that in the words of an ancient Ohio decision, the "true man" may stand his ground in response to an unlawful attack..$^{166}$ In a substantial minority of jurisdictions, however, the defendant must retreat if it is safe to do so. Both sets of jurisdictions tend to restrict this rule to public places; retreat in the home is not required in the vast majority of states, although some jurisdictions make an exception for persons who reside together. ${ }^{167}$ Now consider how imminence may affect retreat rules. If, as my survey shows, imminence serves as a proxy for "alternatives" (at least in some nontrivial set of cases) then imminence may operate as a retreat ruleeven in those jurisdictions or situations that do not require retreat. A court that asks whether the threat was imminent and means by this question whether the defendant had any better, lawful choice is demanding the kind of second-guessing of alternatives that no-retreat jurisdictions do not demand. The jury, told that it need not ask why the

164 For a survey of this debate, see Kahan, 113 Harv L Rev at 429-35 (cited in note 10).

165 LaFave, Criminal Law $\S 5.7(\mathrm{f})$ at 498 (cited in note 6) (stating that "[t]he majority of American jurisdictions holds that the defender ... need not retreat"). Perhaps in a bit of wishful thinking, academics have tended to downplay this rule, occasionally writing as if retreat were the majority rule. See, for example, Paul H. Robinson and John M. Darley, Justice, Liability, and Blame: Community Views and the Criminal Law 54 (Westview 1995) (noting that "codes typically oblige a person to retreat before using deadly force"). Indeed, most scholars, following Beale (great enemy of realists), seem to believe that any rule other than a retreat rule is positively uncivilized. See, for example, LaFave, Criminal Law \$ 5.7(f) at 498 (cited in note 6) (stating that retreat "might be regarded as a more civilized view"); Joseph $\mathrm{H}$. Beale, Retreat from a Murderous Assault, 16 Harv L Rev 567, 582 (1903) (concluding that law exists to control individuals' uncontrolled impulses, "both forcibly and by putting an end to the necessity for their exercise"). Retreat goes to the core of the theory of necessity on which self-defense must rest; one cannot simply assume the proper theory by picking retreat over nonretreat. On competing ideas of necessity, see text accompanying notes 179-200.

166 Erwin v State, 29 Ohio St 186, 199-200 (1876) (stating that the "true man" cannot be expected "to fly from an assailant, who, by violence or surprise, maliciously seeks to take his life or do him enormous bodily harm").

167 LaFave, Criminal Law $\S 5.7(\mathrm{f})$ at 498 (cited in note 6) (noting that "even in those jurisdictions which require retreat, the defendant need not retreat ... from his home"); id $\S 5.7$ (f) at $499 \mathrm{n} 72$ (noting that the "majority view" does not require retreat of co-occupants). 
defendant did not go through the kitchen door, is still invited to ask the same question, albeit in temporal form ${ }^{168}$-did the defendant have the time to go through the kitchen door? ${ }^{169}$ Thus, in the same case, a jury may be told to ignore the fact that the defendant could have run through the door (no retreat rule) and, at the same time, that they must deny the defense if he could have run through the door (imminence rule).

This risk of silent contradiction (imminence taking back what the law gives in other guises) is not limited to a bare majority of jurisdictions that never apply retreat rules. The risk of contradiction operates even in those jurisdictions that typically require retreat. Imagine a case in a retreat jurisdiction in which the court concludes that it will not instruct on retreat because retreat could not be conducted in complete safety or because, as in almost all retreat jurisdictions, retreat is not required in the home. ${ }^{170}$ The court instructs on imminence. We are back again at the same potential inconsistency and, indeed, it has become worse. For, here, the court has specifically concluded that the jury should not be second-guessing alternatives and yet, having instructed on imminence, it may invite the jury to ask that very question. Indeed, the jury may find that the defendant in the confrontational situation should have "run through the door" and reject self-defense even though the court has specifically found that running through the door was dangerous.

Lest this seem academic, consider Ohio's tortured experience with retreat and imminence. ${ }^{171}$ Ohio is a retreat jurisdiction ${ }^{12}$ but, like many such jurisdictions, makes an exception for "the home" (the home is a man's "castle" from which he should not be required to retreat). ${ }^{173}$ At the same time, Ohio defines "imminence" in terms that

168 Since, by definition, time is not an issue in a confrontational case, the jury may well discount the reference to time and simply ask whether there were alternatives.

169 These questions are not, of course, identical. But that is all the more reason to worry whether "time" is serving a covert function as a retreat or other rule.

170 See LaFave, Criminal Law § 5.7(f) at 498-99 (cited in note 6).

171 Ohio is not the only jurisdiction where imminence and retreat have been explicitly conjoined. See, for example, Cooper v United States, 512 A2d 1002, 1004 (DC 1986) (concluding that the jury could consider whether the defendant could retreat in determining whether he was "actually or apparently in imminent danger"). See also notes 117-24 (citing cases and jurisdictions) accompanying text.

172 State $v$ Thomas, 77 Ohio St 3d 323, 673 NE2d 1339, 1342 (1997):

In Ohio, the affirmative defense of self-defense has three elements: (1) the defendant was not at fault in creating the violent situation, (2) the defendant had a bona fide belief that she was in imminent danger of death or great bodily harm and that her only means of escape was the use of force, and (3) that the defendant did not violate any duty to retreat or avoid the danger.

173 Id at $1342-43$ (citations omitted):

[T] here is no duty to retreat when one is assaulted in one's own home.... This exception to 
lower courts have acknowledged sound like a retreat rule: the "imminence" requirement in Ohio is explicitly defined to mean a threat the response to which was the "only means of escape,"174 a threat that "could only be forestalled or escaped by a resort to the use of ... force." "175 most cases, this "imminence-as-retreat" rule may simply seem a redundancy or perhaps an intensifier, requiring retreat "twice" (once in the form of imminence and again in the form of retreat). But, when retreat is not required (for example, when the killing is in the home) conflict can easily arise, with imminence requiring retreat where retreat rules do not. Lower courts have noted this issue but it appears not to have been resolved. ${ }^{176}$ Indeed, the Ohio Supreme Court has actually exacerbated the potential field of conflict by expanding exemptions from retreat while, at the same time, endorsing an imminence rule that seems to define imminence as retreat.

the duty to retreat derives from the doctrine that one's home is one's castle and one has a right to protect it and those within it from intrusion or attack. The rationale is that a person in her own home has already retreated "to the wall," as there is no place to which she can further flee in safety.

174 State $v$ Williford, 1988 Ohio App LEXIS 1906, *22 (noting that "the slayer has a bona fide belief that he was in imminent danger of death or great bodily harm and that his only means of escape from such danger was in the use of such force") (emphasis added).

175 State $v$ Eng, 1994 Ohio App LEXIS 4655, *5-6 (stating that "the Defendant had an honest belief that she or a member of her family was in imminent danger of death or great bodily harm that could only be forestalled or escaped by a resort to the use of such force") (emphasis added). And yet Ohio courts perceive retreat and imminence as separate requirements. See, for example, State $v$ Alvis, 1997 Ohio App LEXIS 3859, *9 (stating that "[b]efore the jury can reach the duty to retreat issue, they must determine if the defendant is in imminent danger of death or great bodily harm").

176 As one court put it: "The [imminence] instruction ... in saying that it must find that defendant's 'only means of escape from such danger was the use of such force' ... places the burden of retreating upon the defendant." State $v$ Wolfe, 1985 Ohio App LEXIS 5696, *5. See also State $v$ Garrette, 1983 Ohio App LEXIS $13965, * 6-7$ (noting defendant's argument that the imminence instruction was inconsistent with the idea that she had no duty to retreat in her home; appearing to agree that the imminence instruction implies a duty to retreat). It is worthwhile to note that these cases were unpublished because they involved the controversial question whether the courts should require retreat for cohabitants, a rule that was disputed primarily (but not exclusively) by battered women. That controversy was esolved only much later by the Ohio Supreme Court. See Thomas, 673 NE2d at 1343 (holding that a person attacked within the home has no duty to retreat).

177 See Thomas, 673 NE2d at 1343 . Early attempts to avoid this potential conflict found that there was a duty to retreat even in the home. See State $v$ Scott, 1995 Ohio App LEXIS 3880, *1215 (unpublished opinion) (rejecting a battered woman defendant's challenge to inconsistent instructions that she had no duty to retreat in the home, but that she had a duty to "avoid the danger"); Garrette, 1983 Ohio App LEXIS 13965 at *6-7 (rejecting a battered woman defendant's claim that an imminence instruction impermissibly imposed a duty of retreat on the theory that the defendant had a duty of retreat in the home). Ohio courts later reversed the position that there was a duty to retreat in the home, first in a case of male-on-male combat, State $v$ Williford, 49 Ohio St 3d 247, 551 NE2d 1279, 1282 (1990) ("there is no duty to retreat from one's home"), and only seven years later (after innumerable cases) in a battered woman's case involving cohabitants. Thomas, 673 NE2d at 1343. 
The skeptic might insist that the conflict between retreat and imminence means little because retreat is only one possible source of contradiction. However, the risk applies as well to other self-defense factors. Consider a case, for example, where imminence operates as a surrogate for motive or emotion. A jury finds, in ruling on a premeditated murder charge, that the defendant did not deliberate, but then, in the course of ruling on self-defense, finds itself concluding that there was no imminent threat because the defendant acted out of revenge rather than fear. A jury has thus found both that the homicide was not deliberate (when it considers mens rea) and deliberate (when it considers imminence). Similar difficulties apply in the case of aggression and provocation. Aggressors are generally denied a selfdefense claim. ${ }^{178}$ Juries are typically instructed that they must determine whether the defendant is in fact the "aggressor." Now imagine a jury that concludes that the defendant is not the "aggressor," but that there was no "imminent threat" because the threat was the defendant's own responsibility (he acted first). The jury will have found both that the defendant was not an aggressor and that he was. And these theoretical possibilities are all heightened by the fact that the clock may be unavailable as an objective referent for "imminence." Remember, in this survey, the vast majority of self-defense cases on appeal raising the imminence issue involved confrontational allegations. In such cases, the law that focuses on imminence simply invites judges and juries to read imminence as a proxy for other factors.

\section{B. Questions of Theory}

Some have suggested that the way out of the imminence dilemma is to focus on "necessity." example, have argued that we eliminate the imminence requirement altogether. ${ }^{180}$ Others have urged that necessity takes priority over im-

178 See LaFave, Criminal Law $\$ 5.7$ (e) at 497 (cited in note 6) (stating that an aggressor generally "may not avail himself of the defense of self-defense").

179 The skeptic might also argue that all I have found is a small subset of the total set of appellate self-defense cases and imminence cases are likely to be a relatively small problem. This is possible, but unlikely. If imminence were limited to cases involving time gaps, it would present a small problem, but this is not how courts appear to be using the requirement. And, even if the relative portion of a full appellate sample were smaller than my survey shows, the critic would still have to show that this kind of confusion does not affect the case at other stages-during charging, jury deliberation, etc.

180 Stephen J. Schulhofer, The Gender Question in Criminal Law, 7 Soc Phil \& Pol 105, 127 (Spring 1990) (arguing that "the traditional insistence on a literally 'imminent' infliction of great bodily harm must be abandoned outright" because the correct inquiry is the necessity of the battered woman's action rather than "imminence per se"). See also Robinson, Criminal Law Defenses $\S 131(\mathrm{~b})(3)$ at 76-77 (cited in note 38) (stating that "proper application of the necessity requirement would seem adequate to prevent potential abuse of a justification defense in cases where the force is not imminent"). 
minence. ${ }^{181}$ Unfortunately, these moves do not resolve the potential for conflict in the law of imminence; they simply transform the question of the meaning of imminence into the meaning of necessity, bringing us to the most fundamental, yet unresolved, questions in the theory of self-defense.

If, as some have asserted, imminence is a "translator" of a necessity principle, ${ }^{182}$ it translates two opposing views of necessitynecessity as aversion to violence (one needs to avoid violence at all costs) and necessity as liberty and right (one needs to respond to wrongful threats). Those theorists, like George Fletcher, who urge that an imminence requirement is essential to a justified self-defense claim, do so based on a theory of self-defense that is heavily invested with pacifism and social responsibility toward the victim's interest in life. The idea is that a defendant's act is justified when necessary, where necessity means that the defendant had "no" alternative but to kill." But this is not the only available view of necessity. Theories of selfdefense that focus on autonomy do so on the basis that "[r]ight need never yield to wrong." when it serves to right the wrong of a deadly attack.

These ideas of necessity, in turn, present two conflicting theories of self-defense: one theory I will dub "pacifist," the other "libertarian."

181 Richard A. Rosen, On Self-Defense, Imminence, and Women Who Kill Their Batterers, 71 NC L Rev 371, 406 (1993) (arguing for a "procedure" that "would retain the imminence requirement in those cases in which it is a translator of the necessity principle, but would remove it when it acts as a potential inhibitor").

182 See id at 380 (stating that "imminence has no significance independent of the notion of necessity"; it is, "in other words, a 'translator' of the underlying principle of necessity, not the principle itself"); Robinson, Criminal Law Defenses $\$ 131(b)(3)$ at 76 (cited in note 38) (noting that imminence should be viewed as a "modification of the necessity requirement").

183 See Fletcher, 57 U Pitt L Rev at 560 (cited in note 2) (discussing the "social point of view" that requires a proportionality rule sensitive to the "competing interest" in life of the aggressor); Fletcher, A Crime of Self-Defense at 33 (cited in note 2) (discussing the "social variation of justifiable self-defense").

184 See Fletcher, 57 U Pitt L Rev at 559 (cited in note 2) ("Necessity speaks to the question whether some less costly means of defense ... might be sufficient to ward off an attack.").

185 See Fletcher, Rethinking Criminal Law $\$ 10.5$ at 865 (cited in note 22) (describing the German theory of autonomy).

186 I have excluded, for textual economy's sake, a comprehensive list of theories of selfdefense, including one of the most popular, the lesser evil approach. See Robinson, Criminal Law Defenses $\$ 131($ a) at 69 (cited in note 38) (stating that "[d]efensive force justifications rely on [a] balancing of evils"). The "lesser evil" approach assumes what I am trying to put into question. It gives us a method-consequentialism - without giving us much to go on in terms of the substance of the "costs" and "benefits" at stake. See Fletcher, A Crime of Self-Defense at 34 (cited in note 2) (attributing to reformers of the 1950s and 1960s the impetus to look for the "costs" and "benefits" of self-defense). Once we begin to consider the "costs" (for example, selfhelp overkill and self-preference) versus the "benefits" (for example, protection of freedom of action), we are back to considering the two elements of the theory considered here-avoidance of violence and autonomy. However, we also have an added "commensurability" problem - how 
need for the defendant to avoid violence. ${ }^{187}$ The libertarian suggests, to the contrary, that self-defense protects the rights of citizens to respond to unlawful aggression. Unfortunately, neither the libertarian nor the pacifist can claim to have won the debate about self-defense. Neither theoretical position actually describes the law of self-defense.

Although the pacifist position has become almost orthodoxy, influencing the work of Professors Fletcher, ${ }^{189}$ Schulhofer, ${ }^{190}$ Robinson, ${ }^{191}$ and Ashworth, ${ }^{192}$ the law of self-defense remains to the contrary. Doctrine, as well as public opinion, is far more willing to insist on the prerogatives of one wrongfully attacked than the pacifist theory suggests or its adherents would hope. ${ }^{193}$ The law positively permits self-help remedies in the majority of jurisdictions, which allow the defendant to "stand his ground" against an attack. Indeed, all jurisdictions permit what might be considered excessive violence in some cases: no jurisdiction, as far as I am aware, limits the right of self-defense to deadly threats. They all include threats of "serious" or "grave" bodily harm."

are we to measure these features against each other? On these and other theories, see generally Joshua Dressler, Justifications and Excuses: A Brief Review of the Concepts and the Literature, 33 Wayne L Rev 1155 (1987) (distinguishing forfeiture, rights, lesser harm, and public benefit theories). Perhaps more importantly, I have purposely sought to rephrase available theory to emphasize the relation between defendant and state, which is important to my claim.

187 See A.J. Ashworth, Self-Defence and the Right to Life, 34 Camb L J 282, 289 (1975) ("This might be termed the 'human rights' approach ... [and it] would result in a general duty to avoid the use of force where non-violent means of self-protection are reasonably open to the person attacked."). It also has affinities with Fletcher's "social variation of justifiable selfdefense" to the extent that it recognizes the rights of the aggressor. See Fletcher, A Crime of Self-Defense at 34 (cited in note 2) ("Recognizing the humanity of the aggressor implies that in some situations the defender must absorb an encroachment on his autonomy rather than inflict an excessive cost on the aggressor."). In theory, I would argue that the pacifist position actually goes much further than the legal academy has thought. It asks whether it is ever possible to be morally justified in killing someone who also has a right to live. See generally Cheyney C. Ryan, Self-Defense, Pacifism, and the Possibility of Killing, 93 Ethics 508 (1983).

188 In a sense this should not be surprising since both positions, one by emphasizing the defendant's relationship to society and the other the defendant's relationship to the victim, focus on different aspects of a defense. It also makes sense because these theories, taken to their logical extreme, would mean either a sharp curtailment of the defense (in the case of the pacifist theory) or an extraordinary expansion (in the case of the libertarian theory).

189 See generally Fletcher, A Crime of Self-Defense (cited in note 2).

190 See generally Schulhofer, 7 Soc Phil \& Pol 105 (cited in note 180).

191 See generally Robinson, Criminal Law Defenses (cited in note 38).

192 See generally Ashworth, 34 Camb L J 282 (cited in note 187).

193 Professors Robinson and Darley express consternation that "Americans [] stereotypically 'stand their ground,' and our subjects seem to want them to even when the legal codes say they should not." Robinson and Darley, Justice, Liability, and Blame at 60 (cited in note 165).

194 See note 65 . Although acknowledging this, treatises routinely attempt to reconcile the "bodily harm" rule with a pacifist view of necessity by arguing that there is an additional "necessity" element that modifies the bodily harm rule. See LaFave, Criminal Law $\S 5.7$ (b) at 492 (cited in note 6) (stating that "deadly force" may be used when the attacker "is about to inflict unlawful death or serious bodily harm" but qualifying the statement by requiring "that it is necessary to use deadly force to prevent it"). Again, from my view, this simply assumes that which is to be proven - the idea of necessity upon which self-defense should be built. Necessity is not a sepa- 
If the law were to take seriously the notion that the defendant should "avoid" violence, why does it not require that defendants warn, announce, or shoot in the air if they could do so safely? And yet there has never been a general "shoot-in-the-foot-first" rule - a defendant need not shoot to disable to sustain a self-defense claim. ${ }^{195}$ If necessity were to mean what the pacifist theory suggests, it would effectively require retreat in every jurisdiction, a state of affairs that does not accord with present doctrine. In short, the law's necessity is not always as "necessary" as it may seem, if by necessary we mean that the defendant must choose the "least violent" or "most pacifist" alternative.

The libertarian claims a far different idea of necessity. This argument emphasizes the wrong inflicted on the defendant and his right to respond. The implicit claim is that the law of self-defense must recognize society's interest in preventing "private warfare," but that if we go too far in discouraging self-help, the citizenry will become the defenseless prey of the violent - that, as A.V. Dicey put it, "loyal subjects [will] become the slaves of ruffians." ${ }^{, 160}$ Under the libertarian theory, the victim's provocative violence constitutes an assertion of superiority over the defendant which must be answered if for no other reason than to support the notion of the "right" - to acknowledge the defendant's acts as those of the law-abiding."

Like its pacifist opponent, however, the libertarian theory fails to describe current doctrine. The law in most jurisdictions refuses to look solely to the "wrong" of the victim/aggressor as the sole measure of

rate element of self-defense; it is a theory which must consistently modify the entire defense.

195 Indeed, courts of the nineteenth century explicitly declined to adopt such a rule. See Rowe v United States, 164 US 546, 558 (1896) ("[I]t was error to make the case depend in whole or in part upon the inquiry whether the accused could, by stepping aside, have avoided the attack, or could have so carefully aimed his pistol as to paralyze the arm of his assailant without more seriously wounding him."); Baltrip v Texas, 30 Tex App 545, 17 SW 1106, 1107-08 (1891) ("Upon the subject of self-defense the [trial] court charged 'that the killing would not be justifiable by self-defense if the apprehended danger of serious bodily harm or death could have been prevented by the use of less violence than taking the life of the deceased.' Under repeated decisions of this court, this charge is erroneous."). This principle is part of Justice Holmes's most famous opinion on self-defense, Brown v United States, 256 US 335, 343 (1921) ("[I]t is not a condition of immunity that one ... should pause to consider whether a reasonable man might not think it possible ... to disable his assailant rather than to kill him.").

196 A.V. Dicey, Law of the Constitution 489 (8th ed 1915):

The rule which fixes the limit of self-help must, from the nature of things, be a compromise between the necessity, on the one hand, of allowing every citizen to maintain his rights against wrongdoers, and the necessity, on the other hand, of suppressing private warfare. Discourage self-help, and loyal subjects become the slaves of ruffians. Over-stimulate selfassertion, and for the arbitrament of the courts, you substitute the decision of the sword or the revolver.

197 See generally Jean Hampton, The Retributive Idea, in Jeffrie G. Murphy and Jean Hampton, eds, Forgiveness and Mercy 111 (Cambridge 1988) (describing punishment (and by analogy violence) as defeat). 
self-defense. Instead, doctrine has consistently conceived of the rules of self-defense in terms that demand that citizens defer to public authorities. Almost all the rules of self-defense can be reconceived not simply as rules that identify "real wrongs" (real threats, real lack of options) but, as well, as rules that create a system that protects society from vigilantism. Rules of proportionality and threat and retreat and imminence insist that, in many situations, defendants walk away, call the constable, and refuse to "substitute the decision of the sword or the revolver" for that of the law.

If the law has never really embraced either the pacifist or libertarian vision of necessity, perhaps it should not be surprising to find both these ideas unresolved in doctrine, submerged in places, like imminence, where they are difficult to see or judge. ${ }^{199}$ But, if this is right, then we cannot confidently solve the imminence "problem" by replacing imminence with necessity, or by claiming priority for necessity, or by demanding that imminence means the pacifist rather than the libertarian version of necessity. Each of these positions simply poses the question; it does not answer it. ${ }^{200}$

\section{Necessity, Excuse, and Justification}

If we cannot answer the imminence question by assuming one side of the necessity debate, neither can we answer it by referring to the distinction between excuse and justification. Some argue, for example, that if we can only decide whether self-defense is an excuse, then we might be able to resolve the problems of subjectivity and the

198 Dicey, Law of the Constitution at 489 (cited in note 196).

199 Jurors often find the law of self-defense quite confusing and, in their questions, reveal conflicts. In Bechtel $v$ State, 1992 Okla Crim 55, 840 P2d 1, 5-6 (1992), a case involving questions about whether a battered wife killed during an extended physical fight, where she claimed that the defendant had raised his arms as if to attack again after a lull in the battle, the jury was unclear about whether this was enough or whether there had to be an "active" confrontation. They not only asked about "fighting and bickering at the time" (the imminence question), but also about necessity: "Self-defense is permitted a person solely because of necessity. (1) Does this mean or imply when no other options are available; or from (2) Defendant's viewpoint \& circumstances." Id at 1, 13-15 (emphasis added). These two options represent the distinction between a pacifist theory (no other options) and a libertarian theory (defendant's needs).

200 Implicit in my claim here and below is that we need a relational theory of self-defense. Unfortunately, current contenders for legal theories of self-defense do not do a very good job of considering the influence of relational norms, preferring to posit "end-states" of affairs (for example, the pacifist's world of no violence) from which to reason. Meanwhile, doctrine shuttles back and forth between an idea of necessity as described by a relationship of fault between attacked and attacker and an idea of necessity as a relationship of citizenship that demands that even the attacked withdraw. Both views are as dichotomously sketched as the early common law distinction between the prevention of a felony and se defendendo. Neither helps in the difficult, in-between cases (most appellate self-defense claims). If we are to resolve this dilemma we must reconsider self-defense in a different key, not as a set of values or functions or end-states but as a question of the key relationships involved between citizens and between citizens and state. 
battered woman, giving her an "excuse," and leaving "real" selfdefense for other claims. Objectivity is then left to the justified side of the debate, subjectivity to the excuse side.

In my view, this confuses two different claims. Every criminal law defense implicates two different relations: the relationship between the defendant and the victim and the relationship between the defendant and the state. ${ }^{201}$ The libertarian theorist focuses almost exclusively on the relationship of "wrong" between the defendant and the victim, making the relationship of the defendant to the state irrelevant. By contrast, the pacifist focuses primarily on the relationship of the defendant to the state, emphasizing that the defendant should defer to state law enforcement processes (and that this is essential to maintain respect for others' right to life). In my own view, both relationships must be considered, not balanced or pitted against each other. Anytime a defendant makes a claim of defense, whether it is a claim of self-defense or duress or provocation, he claims in part that he did no wrong or should be excused from any wrongful harm he did to that victim. But, in considering such defensive claims, there is always the fear that, by recognizing the defense, we grant the defendant the power to legislate, to set the rules. This is, after all, what we mean, presumably, when we claim that Goetz and Menendez and Norman took the "law" into their own hands - that their actions not only risked harm to other human beings but also risked a world in which the defendants' norms were law.

This distinction is important for a number of reasons. But here it is important in defusing the claim that we can solve the problems of self-defense by categorizing the defense as excuse or justification. One of the rarely considered premises of the excuse/justification debate is that defenses are naturally unified. If defenses point toward different audiences, and instantiate different relations, however, then this unity may be illusory. If Bernhard Goetz must not only claim that the boys "wronged" him but also that his use of violence did not offend the state, then it is possible that he is making a claim both of justification vis-à-vis the boys (they were in the wrong relative to him) and a claim of excuse vis-à-vis the state (I should have called the police but the state had failed me in the past). We need not resolve such claims to

201 This is a fairly large theoretical claim. I have also discussed this in the context of provocation. A fuller explication must await publication of a work in progress, V.F. Nourse, The Political Structure of Criminal Law (on file with author). George Fletcher is absolutely right when he maintains that the law of self-defense is related to political theory. See Fletcher, $57 \mathrm{U}$ Pitt L Rev at 570 (cited in note 2) (arguing that the imminence rule "falls into the domain of political rather than moral theory"). Indeed, I believe that until we understand the proper relationship of the defendant to the state implied by the criminal law, we cannot possibly have a working theory of the criminal law consistent with a democratic order and its commitments to equality. 
see that two different issues are at stake, to see that self-defense may be simultaneously a claim of justification with respect to the victim (a question and relation of wrong) and a claim of excuse with respect to the state (I was wrong not to the call the police, but please excuse me). ${ }^{202}$ Put another way, self-defense may (in any individual case) be a claim both of excuse and of justification. And, if that is right, then we cannot confidently claim that the excuse/justification debate solves the problem of either the proper theory of necessity or the meaning of imminence.

\section{Self-Defense and Objectivity}

In the end, what does this tell us of the objectivist position on imminence? It tells us that it is not enough for the objectivist to claim that imminence or even necessity is objective without completing the thought: objective about what? Of the many meanings that imminence might reflect, what meaning is it objective about? Similarly, of the many meanings that necessity might have (I "need" to do this because I want to, my choices are restricted, or I have no choices at all) what meaning are we claiming as objectively determinate? To answer these questions, in the end, requires less of the insistence one tends to hear in the voices of those who cry "but imminence is objective," and more of a tempered and nuanced understanding of the content of the law. Until and unless we can define necessity with some greater degree of coherence, we are relegating ourselves to a law that risks both doctrinal and theoretical incoherence.

Perhaps more importantly, however, this very project requires an acknowledgment that, to be truly objective, one must consider one's relation to the knowledge at issue. Put another way, one must have the humility to consider the possibility that, in another age or social position, in another world, necessity might look quite different. Once, to a charge of murder, the duelist had a valid claim of necessary, justified

202 Debates about Goetz and Norman tend to confuse these two relationships. For example, feminists have charged that to lump Norman in with Goetz is to suggest that a life of virtual slavery is morally equivalent to a request, even a threatening one, for a few dollars. I agree, but I would also add that the feminist claim is focusing on the defendant's relationship to the victim and that there is a separate relationship to consider-between the defendant and the state. Both Goetz and Norman made similar claims about their relationship to the state: both claimed, in essence, that the state had failed them. Goetz claimed that he had been beaten up before, that the state had done nothing, and so he "had" to take the law into his own hands. Far more compellingly, given the history of the state's failure to protect women, Norman argued that the state had failed her. Both were making claims that I would characterize as claims of excuse vis-à-vis the state-claims that they should have called the police in theory but their choices were so severely constrained as to merit compassion for their failures. Whether and how to resolve these latter claims of state failure is a difficult question, but it seems to me it is a better question, and a more interesting one, than those currently asked about these cases. 
self-defense. ${ }^{203}$ Ask the nineteenth-century aristocrat whether, when the glove was thrown, he "had" to act and he will say that he had "no other choice," that it was "necessary"; ask him whether his reasons were "objective" and the answer will be "yes." Today, we are more skeptical about our aristocrats: we think the duelist could easily have walked away; we think (from our distance) that his opinion was, for that reason, subjective (contingent); we see quite easily (from our social and temporal distance) that the duelist "needed" to fight to sustain his social position, one contingent upon a political theory we now disavow. Put more abstractly, we see the "logic" of objectivity in the social and political relations that completed his claims of necessity.

With this humility in mind, we might even pause to consider the possibility that time - so apparently objective - may, from another position, seem more capable of meaning, more contingent, more reflective of social relations than we thought. This is not a claim of crude relativism or even that we give up on the notion of objectivity (at least, as aspiration or even intellectual method). It is a claim that objectivity requires an acknowledgment of its own limitations. Put more pointedly, a more humble aspiration to objectivity might see that there is always the risk that objectivity is simply a "projection racket," one that projects onto the world that which we take for granted-indeed, that objectivity assumes that which it seeks to prove.

\section{SUBJECTIVITY AND FEMINISM}

If the objectivist claim may now appear more contingent and complex than we imagined, I would like to take the argument further and also suggest that what we have seen as subjective may be more objective than we thought. The hope of many, liberals and feminists alike, has been that if only we soften the focus a bit, if we situate the doctrine, if it becomes more sympathetic to the individual, then the law will become more just. In this part, I argue that the subjectivist view tends, much like its objective antagonist, to avoid the problems of self-defense law in its present form. Perhaps more importantly, I urge that, to the extent that subjectivism is associated with the feminist po-

203 Russell Hardin reports that in 1822 a duelist was acquitted based on necessity: The court's justification for the acquittal was "the necessity, according to the existing law of society, of acting as he did." Russell Hardin, One for All: The Logic of Group Conflict 94 (Princeton 1995), quoting V.G. Kiernan, The Duel in European History 208 (Oxford 1989) (emphasis added by Hardin).

204 Those who urge the "objectivity" of the existing law of imminence believe that they are proving its objectivity when, in fact, my argument suggests that they are assuming it. Of course, I must perform the same experiment, and consider whether I have chosen a method, reading the language of cases, that distorts my conclusion in favor of "meaning." Because of this selfreferential risk, I have tried to triangulate my method, looking at history, contemporary law, and work in other disciplines to support the claim that imminence may have meaning. 
sition, it has tended to occlude, rather than expose, certain gender inequalities. I say this because I think that the feminist position is a good deal stronger, and more disturbing, than critics have assumed.

\section{A. The Promise of Subjectivity}

When battered woman self-defense cases first emerged in the late 1970 s, litigators eagerly reached out to the notion of subjectivity to help juries and judges understand the causes and incidents of battering. ${ }^{205}$ This approach, pioneered by the important work of Elizabeth Schneider, revolutionized self-defense law ${ }^{206}$ and led to the wide acceptance of battered woman syndrome evidence. ${ }^{207}$ The theory was that if only juries and judges could understand the individual woman's experience, then self-defense law could be reformed to accord more justice to women. Doctrinally, the reformers suggested that "imminence" is really a question of the battered woman's "perspective" on imminence, i.e. that a battered woman-because of her experience-is more sensitized ${ }^{208}$ to the "cues" signaling violence.

205 See, for example, Elizabeth M. Schneider and Susan B. Jordan, Representation of Women Who Defend Themselves in Response to Physical or Sexual Assault, 4 Women's Rts L Rep 149, 156-57 (1978) (discussing courts' emphasizing subjectivity in self-defense cases with female defendants).

206 See, for example, Ann Shalleck, Theory and Experience in Constructing the Relationship between Lawyer and Client: Representing Women Who Have Been Abused, 64 Tenn L Rev 1019, 1019 (1997) (asserting that feminist activists such as Schneider have "transformed society's understanding of abuse against women by their intimate partners"); Peter Margulies, The Violence of Law and Violence against Women, 8 Cardozo Stud L \& Lit 179, 181 (1996) (arguing that battered woman self-defense law is an "origin story" in the struggle for women's equality under the law).

207 It is worthwhile noting that, early on, Professor Schneider raised important questions about the syndrome, arguing that the testimony was important because it described the experience of battered women but that it could also prove problematic if it focused exclusively on women's victimization. Elizabeth M. Schneider, Describing and Changing: Women's Self-Defense Work and the Problem of Expert Testimony on Battering, 9 Women's Rts L Rep 195, 197, 220 (1986).

208 Battered woman syndrome evidence often relies upon this sensitivity. See, for example, People v Humphrey, 13 Cal 4th 1073, 921 P2d 1, 15-16 (1996) (Brown concurring); Developments in the Law - Legal Responses to Domestic Violence, 106 Harv L Rev 1498, 1582 (1993) (explaining that battered woman syndrome testimony may involve experts testifying that "because a battered woman is attuned to her abuser's pattern of attacks, she learns to recognize subtle gestures or threats that distinguish the severity of attacks").

209 One can be quite sympathetic to these perceptual claims as a psychological matter (which I am) and still wonder whether they really help resolve the problem. Mark Kelman has asked some very tough questions about the notion of heightened perception, suggesting that it may not really differentiate the battered woman from claimants like Bernhard Goetz who similarly rely upon a history of violence to support their claims of imminent and serious threat. Mark Kelman, Reasonable Evidence of Reasonableness, 17 Critical Inquiry 798, 813-14 (1991). My own view is that our intuitions differ in these cases not because of the prior history (the law has always conceded that history may have some effect upon the propriety of a self-defense claim), or necessarily perception, but because the normative baseline of the relationships involved colors our view of the relevance of the history. In Goetz, we suspect that the defendant sought to domi- 
This approach appealed to many because it unified criminal law theory's focus on individuation of the criminal law (emphasizing the individual characteristics of defendants) with the needs of women. ${ }^{210}$ And, for that reason, it met with a great deal of initial success. Jurisdictions flirted with or adopted "reasonable woman" standards; ${ }^{211}$ indeed, a majority have, by legislative fiat if not judicial decision, permitted the admission of expert syndrome testimony based on the defendant's "subjective state," known as battered woman syndrome. ${ }^{212}$ And, if there has been some moderation in this effort, yielding for the most part standards that are both objective and subjective, it has been increasingly successful in sensitizing courts to the dilemmas of battering as well as constructing the academic debate along the lines of "subjective" versus "objective" standards. ${ }^{213}$

More recently, however, the subjectivized approach has come under substantial, and in some cases, intemperate, attacks from the criminal law academy. Some have insisted that a subjective approach towards self-defense encourages lawlessness by allowing battered women to kill with impunity long after the threat has subsided. ${ }^{214}$ Crit-

nate his attackers because of a view of his inherent racial and other superiority toward his victims; in the battered woman case, we see the woman as seeking to assert her dignity in the face of an assertion of superiority by her attacker/mate. Because the history of violence purports to be neutral with respect to these relationships (both have a history of violence and have a heightened awareness of its cues), neither history nor perception appears, to provide a distinction between the cases, unless one views the nature of the relationship at issue.

210 See David A.J. Richards, Introduction to Symposium on Self-Defense and Relations of Domination: Moral and Legal Perspectives on Battered Women Who Kill, 57 U Pitt L Rev 461, 463 (1996) (noting that Schneider pioneered self-defense arguments for battered women in terms of principles of individualization).

211 See, for example, State $v$ Wanrow, 88 Wash 2d 221, 559 P2d 548, 559 (1977) (noting that self-defense instructions must "afford women the right to have their conduct judged in light of the individual physical handicaps which are the product of sex discrimination"). See generally Naomi R. Cahn, The Looseness of Legal Language: The Reasonable Woman Standard in Theory and Practice, 77 Cornell L Rev 1398 (1992) (surveying and critiquing this development).

212 As of 1994, one study found that "[e]xpert testimony on battering and its effects" had been held admissible, at least in part, in "each of the 50 states and the District of Columbia" and that "[t]welve states have enacted statutes providing for the admissibility of expert testimony." The report noted, however, that " 18 states have also excluded expert testimony in some cases." Janet Parrish, Trend Analysis: Expert Testimony on Battering and Its Effects in Criminal Cases, 11 Wisc Women's L J 75, 83 (1996). A subsequent government study had somewhat different findings, noting potentially greater diversity among the states, but concluded that nearly 70 percent of the states have found expert testimony "relevant to supporting a self-defense claim" and to the defendant's "state of mind." See The Validity and Use of Evidence Concerning Battering and Its Effects in Criminal Trials: Report Responding to Section 40507 of the Violence against Women Act, NCJ 160972 (May 1996), cited in Clare Dalton and Elizabeth Schneider, Battered Women and the Law 746 (Foundation 2001).

213 See, for example, Richards, 57 U Pitt L Rev at 464 (cited in note 210) (explaining that facts concerning battered women, when properly introduced under an individualized standard, help juries understand how and why a battered spouse might reasonably kill in self-defense).

214 See Dershowitz, Abuse Excuse at 5 (cited in note 3) (suggesting that battered woman nonconfrontational claims "threaten the very fabric of democracy"). 
ics from the left and right have no hesitation in likening battered women to executioners. ${ }^{215}$ Nor do they - and a good many othershave any hesitation in linking this development with unhappy trends in the law. ${ }^{216}$ In the late 1990 s, for example, there was a growing academic chorus charging that the problem with the criminal law was that it had become too soft and subjective, and that battered woman cases were, at least in part, responsible for that development.

\section{B. Imminence as Retreat Rule}

The feminist emphasis on subjectivity has appeared to be a claim that there is nothing really wrong with the "objective" rules that "subjectivity" cannot cure. If my survey is right, though, there may well be things that are "wrong" with the rules, at least where the rules are considered as reflective of relational norms. Consider what we know from my discussion of imminence and retreat. The feminist position has generally been hostile to retreat rules on the theory that they too easily dissolve into questions about why the woman did not leave the relationship rather than whether the knife was poised above her head. ${ }^{218}$ By the 1990s, feminists had largely given up the battle, however, thinking that it had largely been won.

There were good reasons for thinking retreat was not such an important doctrinal issue. For one thing, most jurisdictions do not re-

215 Fletcher, 57 U Pitt L Rev at 556 (cited in note 2) (discussing the case of Judy Norman, who killed her sleeping husband, as one in which she put herself "in the position of judge and executioner"); Wilson, Moral Judgment at 62-66 (cited in note 3) (discussing battered women's nonconfrontational killings and suggesting that transformation of the concept of necessity would authorize "private, paid executions" in such cases). Appellate judges have often engaged in this rhetoric as well. See, for example, State v Stewart, 243 Kan 639, 763 P2d 572, 579 (1988) (stating that allowing a self-defense claim for the killing of a sleeping husband would "in effect allow the execution of the abuser for past or future acts and conduct").

216 See, for example, Faigman and Wright, 39 Ariz L Rev at 79 (1997) (cited in note 4) (arguing that "[t]he integrity of legal doctrine has suffered immensely" from the spread of syndrome evidence aimed at aiding battered women).

217 For general discussions, see Wilson, Moral Judgment (cited in note 3); Downs, More Than Victims (cited in note 3); Dershowitz, Abuse Excuse (cited in note 3).

218 See, for example, Cynthia K. Gillespie, Justifiable Homicide: Battered Women, SelfDefense and the Law 187-88 (Ohio State 1989) (arguing that rules requiring retreat in the home are especially unfair to women defendants); Christine A. Littleton, Women's Experience and the Problem of Transitions: Perspectives on Male Battering of Women, 1989 U Chi Legal F 23, 36 (arguing that retreat rules fail to comprehend the danger of attempting to leave the abusive situation and thus make "a mockery of the standard self-defense analysis regarding 'duty to retreat"').

219 In her survey, for example, Holly Maguigan found the doctrine of retreat led to few "bad" trial outcomes. See, for example, Maguigan, 140 U Pa L Rev at 419 (cited in note 5) (finding that "[a] survey of the cases analyzed shows that the duty to retreat was generally not the cause of bad trial outcomes and that, in most of those cases where it was outcome-determinative, it was the result of the rule's application rather than its definition"). 
quire retreat "in the home," another, to the extent jurisdictions had exceptions to the castle rule for "cohabitants" (which would require a battered woman to retreat against her husband), courts have increasingly rejected such rules as unfair to battered women, leaving the "retreat" problem to a few nonconforming jurisdictions. ${ }^{2 m}$ Finally, almost all jurisdictions adopting syndrome evidence have accepted the position that leaving is not the proper question in these cases. ${ }^{23}$

If, however, my survey is right, eliminating "retreat" rules is not necessarily going to solve the "retreat" problem. If, as we have seen above, imminence (or necessity or any other factor), may operate as a proxy for a retreat rule, then we are back at square one. It is still possible that in battered woman cases a jury or judge will ask, via imminence, whether the defendant should have run through the kitchen door, or had a "five-minute head start," even if there is no retreat rule. More importantly, once it becomes possible that imminence (or necessity or other factors) can act as a silent retreat rule, the retreat problem is no longer limited to a few jurisdictions but applies to a vast ar-

220 Retreat is generally not required in one's home. See State $v$ Thomas, 77 Ohio St 3d 323, 673 NE2d 1339, 1343 (1997) ("The majority of jurisdictions in the United States have held that there is no duty to retreat when one is attacked in one's own home, regardless of whether or not the assailant has a right to be in the home equal to that of the one being assailed."). See also Maguigan, $140 \mathrm{U} \mathrm{Pa} \mathrm{L} \mathrm{Rev} \mathrm{at} \mathrm{419-20} \mathrm{(cited} \mathrm{in} \mathrm{note} \mathrm{5)} \mathrm{(finding} \mathrm{that} \mathrm{most} \mathrm{jurisdictions} \mathrm{imposing} \mathrm{a}$ duty to retreat "exempt from the duty to retreat those defendants who are attacked in their own homes"); Martha R. Mahoney, Legal Images of Battered Women: Redefining the Issue of Separation, 90 Mich L Rev 1, 83 n 373 (1991) (same).

221 See Maguigan, 140 U Pa L Rev at 420 n 141 (cited in note 5) (finding that over two thirds of confrontational and nonconfrontational cases studied occurred in the home).

222 See, for example, Thomas, 673 NE2d at 1343 (holding there is no duty to retreat from one's own home before resorting to lethal force against a cohabitant with an equal right to be in the home); Commonwealth v Derby, 451 Pa Super 100, 678 A2d 784, 785 (1996) (same); State v Brown, 117 NC App 239, 450 SE2d 538, 540-41 (1994) (same); Bechtel v State, 1992 Okla Crim $55,840 \mathrm{P} 2 \mathrm{~d} 1,13$ (noting that a person has no duty to retreat where he is not an aggressor and is "in a place he has a right to be"). But see State v Gartland, 149 NJ 456, 694 A2d 564, 569 (1997) (stating that "New Jersey is among the minority of jurisdictions that impose a duty of retreat on a woman attacked by her cohabitant spouse").

${ }_{223}$ See, for example, Smith v State, 268 Ga 196, 486 SE2d 819, 822 (1997) (reporting that "[e]xpert testimony was admitted to explain 'why a person suffering from battered woman syndrome would not leave her mate, would not inform police or friends and would fear increased aggression'"), quoting Smith v State, 247 Ga 612, 277 SE2d 678, 683 (1981); State v Koss, 49 Ohio St 3d 213, 551 NE2d 970, 973 (1990) (stating that " [e]xpert testimony on the battered woman syndrome would help dispel the ordinary lay person's perception that a woman in a battering relationship is free to leave at any time'"), quoting State v Hodges, 239 Kan 63, 716 P2d 563, 567 (1986); State $v$ Kelly, $97 \mathrm{NJ} 178,478$ A2d 364, 377 (1984) (noting that "[t]he crucial issue of fact on which this expert's testimony would bear is why, given such allegedly severe and constant beatings, combined with threats to kill, defendant had not long ago left decedent"). See also Commonwealth $v$ Watson, $494 \mathrm{~Pa} 467,431$ A2d 949, 951-52 (1981) (stating that "[a] woman whose husband has repeatedly subjected her to physical abuse does not, by choosing to maintain her family relationship with that husband and their children, consent to or assume the risk of further abuse"). 
ray of jurisdictions. The syndrome may provide some counterweight to this by instructing the jury about the difficulty of leaving, but since this is offered as scientific fact and character trait rather than as legal proposition, it may be inapplicable to any individual defendant not fitting the appropriate psychological profile.

Indeed, in some jurisdictions, the conflict between imminence and retreat sits on the face of the rules. For years, Ohio's lower courts struggled with the question whether, in cases arising in the home, cohabitants should have to retreat. Eventually, the state supreme court decided, following the trend in other jurisdictions, to adopt a rule that seemed "friendly" to the battered woman. ${ }^{224}$ It said that battered women do not have to retreat in their homes. But in that very case, the court approvingly quoted jury instructions requiring a finding that the defendant had no "other alternatives" of an "imminent" threat. What may seem, then, on the surface to be a gain for battered women in retreat rules may not be the gain it promised to be, if a court may take back with imminence what it has given on retreat.

The conflation of retreat and imminence is particularly problematic in battered woman cases because of the role that "leaving" plays in common intuitions about these cases. As courts themselves have made clear, the practice, if not the law, ${ }^{227}$ of battered woman cases revolves around the question whether "she should have left." As the court put it in State $v$ Kelly, "the crucial issue ... is why, given such allegedly severe and constant beatings, combined with threats to kill, defendant had not long ago left decedent."229 In this atmosphere, where experts and lawyers and judges are all thinking, if not talking, about the question of leaving, retreat becomes the kind of "unconscious" of the battered woman's case, driving the lawyers' arguments

224 Thomas, 673 NE2d at 1343 . See also text accompanying notes 220 and 222.

225 Id at 1344 (recounting jury instruction stating that, to find for the defendant on the question of self-defense, the jury on the "imminence requirement" must find that "Teresa Thomas [the defendant] had an honest belief that she was in imminent danger of death or great bodily harm and that her only means of escape from that danger was in the use of such force") (emphasis added).

226 This problem should not be seen as limited to those jurisdictions with an overt inconsistency, such as Ohio. Even if there is no explicit doctrinal inconsistency, there is no guarantee, given courts' ability to tolerate this at an explicit level, that it might not be tolerated in any individual case at the application stage. More importantly, this is not the only kind of inconsistency possible; it is only the most dramatic, the one that has the starkest implications given the continuing debate about the wisdom of a retreat rule.

227 See text accompanying note 223 .

$22897 \mathrm{NJ} 178,478$ A2d 364 (1984).

229 Id at 377 ("Whether raised by the prosecutor as a factual issue or not, our own common knowledge tells us that most of us, including the ordinary juror, would ask himself or herself just such a question."). 
and the jury's deliberations. ${ }^{230}$ Overwhelmingly, courts have attempted to thwart such assumptions by embracing battered woman syndrome testimony - testimony intended, in large part, to explain that such assumptions fail to describe the situation of the battered defendant. ${ }^{23}$

The problem extends further, however, than the potential question of "leaving"-it extends as well to the ways in which imminence may absorb other norms disfavoring battered women. Courts have refused to accept, as law or fact, the proposition that battered women naturally invite this violence or provoke the attack or that the battered woman's situation reduces fear. ${ }^{232}$ And, yet, if imminence is capable of absorbing meanings of motive and provocation, meanings associated with responsibility for the violence, it should not be surprising to find that these norms may be recapitulated in battered woman cases-despite testimony or instructions to the contrary. ${ }^{233}$ Put another way, the jury instructed that it cannot assume women provoke violence may find that there was no imminent threat, not because the gun was not pointed at the defendant, but because they believe the defendant was in some sense responsible for "dating other men." ${ }^{234}$ And, if that is right, shouldn't these same courts worry that they are creating

230 See Elizabeth M. Schneider, Equal Rights to Trial for Women: Sex Bias in the Law of Self-Defense, 15 Harv CR-CL L Rev 623, 624-27 (1980); Mahoney, 90 Mich L Rev at 7 (cited in note 220).

231 See text accompanying notes 212 and 223.

232 Battered woman syndrome testimony is seen not only as relevant to the question of why the defendant did not leave, but also to the question of provocation and fear. See, for example, People v Humphrey, $13 \mathrm{Cal}$ 4th 1073, 921 P2d 1, 8-10 (1996) (indicating battered woman syndrome testimony relevant to rebut the prosecutor's argument that the threat on the day of the killing was no more serious than it previously had been and therefore should not have inspired fear of imminent danger); Brooks v State, 630 S2d 160, 161-62 (Ala Crim App 1993) (recounting the testimony of an expert on battered woman syndrome that "[f]or a long time women who stayed in battering relationships were felt to be either masochistic or to be emotionally disturbed or else why would they stay. And the literature has not supported either of those theories. It basically says they stay because they are afraid."). For a general discussion, see Parrish, 11 Wisc Women's L J at 75 (cited in note 212) (providing trend analysis on expert testimony concerning battered woman syndrome).

233 See, for example, Bonner v State, 740 S2d 439, 441-44 (Ala Crim App 1998) (recounting that "the State countered the appellant's claim of self-defense by arguing that she continued in the allegedly abusive relationship with the victim, thereby creating an inference that she was not afraid of the victim," and rejecting the state's argument); Humphrey, 921 P2d at 11 (noting that the state argued that the victim's threat on the day of the killing "was like so many threats before," with the implication that she had no reasonable ground for fearing imminent deadly violence; ordering the lower court to allow battered woman syndrome evidence in opposition to this argument); Ibn-Tamas v United States, 407 A2d 626, 633-34, 640 (DC App 1979) (stating that "the government implied to the jury that the logical reaction of a woman who was truly frightened by her husband (let alone regularly brutalized by him) would have been to call the police from time to time or to leave him"; remanding for a redetermination of the admissibility of battered woman syndrome evidence to rebut this proposition).

234 See Stonehouse, 555 A2d at $781 \&$ n 5 (noting and rejecting the prosecutor's argument that the defendant provoked violence by dating other men). 
the same rule, via imminence, that they have disavowed under other guises?

This is not a claim of disparate treatment or impact in the conventional sense. That the law may impose on the battered woman a retreat rule in non-retreat jurisdictions, or embrace a variety of other potentially contradictory meanings, is not unique to battered woman cases - as we have seen, it may happen in barroom brawl cases as well. Moreover, I can make no claim that there is a statistically disparate impact of such a rule-neither I nor anyone is likely to know how often this kind of inconsistency happens in real life, as opposed to what happens in reported cases. Instead, this is a claim of constitutive feminism - a claim that an objective inconsistency in the rules depends upon and thus constitutes relational inequality for women. As I show below, the problem for the battered woman is not simply that imminence bears undeclared meaning but that its meaning may be created in the image of her relation to men, a relation that may become more powerful than the rules.

\section{A pre-retreat rule for battered women?}

It is one thing for jurors or judges to confuse imminence with "leaving the confrontation"; it is another to confuse it with "leaving the relationship." A retreat rule may require the defendant to withdraw once the confrontation has begun, ${ }^{235}$ but a rule that demands the defendant "avoid the confrontation" is an entirely different requirement; such a "pre-retreat" rule is far more severe and, indeed, has never been part of standard self-defense law. There is no general duty to avoid violence before the confrontation. ${ }^{236}$ The man who goes for the fiftieth time to the violent gang-bar is not deprived of his selfdefense claim because he "should have left" before the violence erupted. Indeed, as one of the critics of such a rule acknowledges, the common law of self-defense protects the freedom to move. ${ }^{237}$ To be

235 See LaFave, Criminal Law $\S 5.7(f)$ at 497-99 (cited in note 6).

236 As Richard Rosen has colorfully summarized the law:

No matter how clear it was to Gary Cooper that somebody would end up dead if he did not leave before the train carrying his enemy arrived at "High Noon," our culture allows him to stay in town and affords him the right to kill in self-defense when the bad guys come after him.

Rosen, 71 NC L Rev at 396 (cited in note 181). See, for example, State v Bristol, 53 Wyo 304, 84 P2d 757, 766 (1938) (holding that the defendant had no duty to avoid entering a bar where he knew his adversary, who had threatened to attack him, to be drinking); Ball $v$ State, 29 Tex App 107, 14 SW 1012, 1013 (1890) ("Defendant's presence at the place where the killing occurred could not, under the circumstances, constitute provocation to the deceased.").

237 As Andrew Ashworth has put it, American law respects the defendant's autonomy even to a greater degree than does British law, which excepts from a duty to avoid violence claims in "those cases where [the defendant] is acting lawfully in remaining at, or going to, a place." An- 
sure, the law of self-defense does reject the self-defense claims of those who "provoke" the violence or "create the conditions" of their own defense. ${ }^{238}$ The only problem is that, when applied to the relationship (and not the violence), these principles create a rule that the law has never announced-that a defendant can be said to have "provoked" a confrontation simply by "staying" - in this case, in a relationship. That is a norm that courts have openly and consistently denied. ${ }^{239}$

To say that the application of a common sense "pre-retreat" rule is contrary to the law of most jurisdictions is, of course, not to say that one might not urge one, as scholars have. Stephen Schulhofer has argued, for example, that we should ask of women why they did not leave. ${ }^{240}$ More generally, Andrew Ashworth has argued that avoidance of violence should be the proper norm for all cases, although he acknowledges that this is not the rule in America where the law of selfdefense has always jealously protected the defendant's autonomy. ${ }^{241}$ One need not resolve that question (a deep one about the theory of necessity) to argue that there may be a problem with applying an implied "pre-retreat" rule in battered woman cases if American law does not apply that rule to the man in the dangerous bar or neighborhood. To ask of battered women that they leave-in whatever doctrinal guise (imminence, retreat, threat, etc.) - raises serious questions about whether the law of self-defense treats battered women less favorably than others.

\section{Seeing confrontational cases as confrontational.}

The argument is really deeper, however, than whether the rules are consistent, or whether objectivity predicts differential treatment. It is a question in the end of practice - of what happens before the rules, what happens in our images of life that makes us apply one rule rather

drew Ashworth, Principles of Criminal Law 119 (Clarendon 1991).

238 Robinson, 2 Criminal Law Defenses \$131(b) at 74 (cited in note 38).

239 See, for example, Commonwealth v Watson, $494 \mathrm{~Pa} 467,431$ A2d 949, 951-52 (1981)

(stating that "[a] woman whose husband has repeatedly subjected her to physical abuse does not, by choosing to maintain her family relationship with that husband and their children, consent to or assume the risk of further abuse"). See text accompanying note 223 (discussing battered woman syndrome's rebuttal of the stereotype that women are masochistic or must leave to be believed).

240 Schulhofer, 7 Soc Phil \& Pol at 128-29 (cited in note 180) ("[W]e cannot forgo all punishment if the circumstances afforded the [abused] woman some alternative.... Conviction and some punishment remain appropriate so long as the social and economic circumstances ... did afford some reasonable alternative to the use of deadly force."). Schulhofer does go on to note that "tangible barriers to flight" should be relevant to the question of a "reasonable available remedy" short of violence. Id at 129.

241 See, for example, Ashworth, 34 Camb L J at 296 (cited in note 187) (urging that the defendant in such situations should be made to inform the police even if that is not the prevailing English rule). 
than another and recreate that life in those rules. Battered woman cases are in general not seen as "real fights"-it is assumed, at the start, that one is referring to the killing of a sleeping man. ${ }^{242}$ The important point my survey suggests is that even when the cases are confrontational-when the gun is pointed at her-they still are not seen as confrontational. Imminence is one of the ways in which the threat is not seen: in Watson, ${ }^{243}$ the trial court literally cannot "see" the hands around her neck, not because the judge has not heard the testimony, but because the judge implicitly places responsibility on her for those hands - she should have left before the hands got there. ${ }^{244}$

Put another way, courts and commentators have trouble seeing confrontational cases as confrontational because of their normative assumptions about what the parties' relationship entails; the structure of the parties' relation determines the post hoc view, the "objective" view of not only the temporal transaction but also its confrontational character. When the gun is pointed at the male defendant in the bar, there is an imminent confrontation; when it is pointed at Barbara Stonehouse, who was stalked by an ex-boyfriend, there is a question about whether the threat was imminent and serious. ${ }^{245}$ Similarly, when the beer bottle is about to be thrown after a barroom brawl, few doubt that a self-defense instruction is appropriate. But when it is about to be thrown at Betty Hundley by the husband from whom she fled, the court talks of imminence and the dissenting judge insists she could have had a five-minute "head start.",245

The point is that the norms of the relation are more powerful than the law in shaping our intuitions about self-defense cases. ${ }^{247} \mathrm{Im}$ minence and confrontation are concepts formed in the image of social, pre-legal, norms about the relative responsibility of the parties. Divorced from their relational context, the battered woman cases look

242 See notes 8,30 . See also text accompanying note 30 (discussing the assumptions of scholars that most battered woman cases do not fall into the standard self-defense paradigm).

243494 Pa 467, 431 A2d 949 (1981).

244 To say that the victim needed to leave before the hands were around her neck opens the time frame to the past-away from the confrontation. The judge in Watson cannot "see" that there is a confrontation because he has judged fault from a perspective that has projected the self-defense claim back into the history of the relationship. She was at fault for hours, days, and weeks before the hands were around her neck. Here, time-framing is a function of social norms - we look back because we believe that she is somehow responsible for the relationship.

245 Commonwealth $v$ Stonehouse, $521 \mathrm{~Pa} 41,555$ A2d 772, 780, 783 (1989). See note 147.

246 State $v$ Hundley, 236 Kan 461, 693 P2d 475, 478-80 (1985). Id at 481 (McFarland dissenting).

247 Here is the intellectual progression: The judge says that the defendant has no claim of self-defense because of the "objective" requirement of "imminence." But it turns out that by "imminence" he cannot mean time, because the hands are around her neck. It turns out that imminence means for him that she "had alternatives." Her response was not "necessary," where necessity and imminence, and its objectivity, are all constructed, and completed, by an unacknowledged claim that women need to leave-a pre-retreat rule. 
very much like the male cases - they are cases of weak threats in a violent context. The defendant says that there was a "glint" of a gun, or it looked like the victim was reaching for a gun, or the victim's hands were raised as if to attack. ${ }^{248}$ Surely, the man who claims that he heard a rustle in the bushes outside his cabin has a weak self-defense claim. $^{249}$ But few say, automatically, that he could have had a fiveminute head start, or that he should never have bought the house in such an isolated spot. Even fewer say that to grant a self-defense instruction in his case is to risk the downfall of the criminal law. In the end, the battered woman cases tell us that it is her relationship to the victim that may be the most powerful influence, affecting whether we see the threat as imminent, the case as confrontational, or her response as necessary. Put another way, it is her relation that silently completes the law's claimed objectivity.

\section{Battered Woman Syndrome}

If I am right, then the arguments for battered women cannot simply be dismissed as claims for "subjectivity" or "special treatment." Critics will respond that objectivity cannot account for battered woman syndrome evidence-evidence that is synonymous, for many, with increased "subjectivity" in the law. I believe there is good reason to reach just the opposite conclusion, that syndrome evidence is not the enemy, but the essential ally, of an "objective" law of self-defense. If that is true, then traditionalists may need to reexamine whether their fears of the syndrome may well be exaggerated, and subjectivists need to examine whether the argument of subjectivity is really too weak a defense of the normative propositions contained in the syndrome.

Scholars, writing for both academic and popular audiences, have reviled the syndrome, urging that it lacks scientific validity and wreaks havoc with the law of self-defense. ${ }^{230}$ And yet battered woman syn-

248 See, for example, State v Fuller, 297 SC 440, 377 SE2d 328, 331 (1989) (reversing for failure to instruct that the defendant could have acted in self-defense based on the fact that he saw the victims "open the trunk of their car and also thought he saw a shiny object in Dixon's hand"). See also People $v$ Spencer, 51 Cal App 4th 1208, 1216 (1996) (describing the claim that the defendant shot when the victim "reach[ed] down to the floorboard of the car"; defendant convicted of voluntary manslaughter).

249 State v Negrin, 37 Wash App 516, 681 P2d 1287, 1290 (1984) (describing claim in which defendant shoots into woods because he hears noise).

250 See, for example, Wilson, Moral Judgment at 48-58 (cited in note 3) (arguing that expert testimony on battered woman syndrome is replacing individual accountability). See also Faigman, Note, 72 Va L Rev 619, 631-40 (cited in note 30) (stating that battered woman defendants "seek to stretch self-defense doctrine's imminence requirement almost to infinity" and criticizing the scientific methodology of Lenore Walker's research on battered woman syndrome). 
drome testimony is widely accepted across the nation..$^{251}$ Indeed, courts in many jurisdictions have applied syndrome evidence to a wide array of claims-claims of siblings and children, and the odd battered male..$^{252}$ Whether those rulings are correct, they exist and are not particularly controversial for courts, raising the question why courts (not typically dominated by radical feminists or subjectivists) have been so welcoming to the syndrome, while the critics remain so insistent that the syndrome is not only bad science but also bad law.

I think some explanation can be found for this by recognizing, at the start, how conventional the syndrome is (something its critics recognize, I believe). But, to do that, one must first put claims of psychology and cycles aside. As its earliest advocates have told us, efforts to inject battered woman syndrome into criminal trials sought to tell a different normative tale than the one society had long used to understand this kind of violence. In the form of a description about battered women, the syndrome really offers reasons why the law should not blame women for the battering. It tells us that women who suffer prior threats are likely to suffer future violence, implying that we should believe her when she claims the threat was serious. It tells us that women are not masochistic, implying that women should not be assumed to have provoked the violence. It tells us that women are attuned to threats, implying that the threats are real and well understood. It tells us that women are afraid, implying that they did not act out of revenge. It tells us that it is very difficult to leave, implying that women should not be blamed for failing to leave.

251 See note 212 .

252 See, for example, People v Colberg, 182 Misc 2d 798, 701 NYS2d 608, 608-10 (County Ct 1999) (holding battered person syndrome evidence admissible in case of father accused of murdering adult son); State v Nemeth, 82 Ohio St 3d 202, 694 NE2d 1332, 1334 (1998) (finding battered child syndrome evidence admissible in case of child accused of murdering parent); State $v$ Janes, 121 Wash 2d 220, 850 P2d 495, 501-03 (1993) (same); Commonwealth v Kacsmar, $421 \mathrm{~Pa}$ Super 64, 617 A2d 725, 730-33 (1992) (holding battered person syndrome evidence admissible in case of fratricide), disapproved in part on other grounds, Commonwealth v Miller, $430 \mathrm{~Pa}$ Super 297, 634 A2d 614 (1993).

253 See Faigman and Wright, 39 Ariz L Rev at 75 (cited in note 4) (claiming that the syndrome is bad science); Wilson, Moral Judgment at 58 (cited in note 3) (stating that the syndrome is unnecessary); Fletcher, 57 U Pitt L Rev at 571 (cited in note 2) (stating that the syndrome is inconsistent with the question of justification). Of course, as a legal matter, there is no separate "battered woman" defense. Or, at least, courts continually so state. See, for example, State v Koss, 49 Ohio St 3d 213, 551 NE2d 970, 974 (1990) ("Thus, admission of expert testimony regarding the battered woman syndrome does not establish a new defense or justification. Rather, it is to assist the trier of fact [in determining] whether the defendant acted out of an honest belief that she was in imminent danger of death or great bodily harm.").

254 Even those who reject the syndrome acknowledge that the cycle theory addresses "essential aspects of the law of self-defense," including "the defendant's knowledge of the aggressor's history of violence," the "reasonableness of the amount of force used," her "perception of harm," and "why battered women fail to leave violent relationships." Faigman and Wright, 39 Ariz L Rev at 73, 75 (cited in note 4). 
If we reduce the syndrome testimony to the normative propositions associated with these descriptions - if for example, we imagine them to be jury instructions rather than expert testimony ${ }^{2 s 5}$-then the syndrome is consistent with some very standard propositions in the law of self-defense, so standard, they could all be supported by nineteenth-century law citations. Take, for example, the proposition that prior threats and violence increase the credibility of a claim of future violence. Since the nineteenth century, past threats and violence, including the victim's character for violence, have been considered highly relevant to a claim of self-defense, on questions of imminence and aggression, and the nature of the threat. ${ }^{266}$ Or consider the proposition that a woman's claims should be judged from her position, according to her situation. In 1888 , courts would charge juries that the reasonable person is not to be judged by some "ideal" standard but that the members of the jury were to put themselves "in the position of the assailed person, with his physical and mental equipment, surrounded with the circumstances and exposed to the influences with which he was surrounded, and to which he was exposed at the time.".557

255 I make absolutely no claim about the psychological validity of the syndrome; my claim is purely based on its normative propositions.

256 See, for example, Allison v United States, 160 US 203, 215 (1895):

Here the threats were recent and were communicated, and were admissible in evidence as relevant to the question whether defendant had reasonable cause to apprehend an attack, fatal to life or fraught with great bodily injury, and hence was justified in acting on a hostile demonstration and one of much less pronounced character than if such threats had not preceded it. They were relevant because indicating cause for apprehension of danger and reason for promptness to repel attack.

See also People v Thomson, 92 Cal 506, 28 P 589, 590 (1891):

Under these circumstances, all the acts and conduct of the deceased, either in the nature of overt acts of hostility, or threats communicated or uncommunicated, were proper evidence to be considered by the jury as shedding light - to some extent at least-upon the issue as to whether the deceased or the defendant was the aggressor in this fatal affray. These principles are elementary in criminal law, and a citation of authorities not demanded.

See also Marts $v$ State, 26 Ohio St 162, 168 (1875) ("[T]he court erred in ruling out the evidence of the violent, vicious, and dangerous character of the deceased.") (emphasis added).

257 The court charged the jury that in determining whether the defendant's apprehension of imminent death or grievous bodily harm was reasonable, the "jury are not to conceive of some ideally reasonable person." United States v King, 34 F 302,309 (E D NY 1888) (emphasis added). See also United States v Lewis, 111 F 630,636 (W D Tex 1901) (employing very similar language); Carleton v State, 43 Neb 373, 61 NW 699, 710 (1895) (instructing the jury to ask, "What would a reasonable person, a person of ordinary caution, judgment, and observation, in the position of defendant, seeing what he saw and knowing what he knew, suppose from this situation and these surroundings?"); People v Bruggy, 93 Cal 476, 29 P 26, 27 (1892) ("The rule in such a case is this: What would a reasonable person, - a person with ordinary caution, judgment, and observation in the position of the defendant, seeing what he saw, and knowing what he knew, suppose from his situation and his surroundings?") (emphasis added); People v lams, 57 Cal 115, 119 (1880) ("The rule in such cases is this, What would a reasonable person-a person of ordinary caution, judgment, and observation - in the position of the defendant, seeing what he saw, and knowing what he knew, supposed from this situation and these surroundings?") (emphasis added). 
Consider the claim that it is the defendant's perception or perspective that counts rather than the actual threat. It was well-established in the nineteenth century that the defendant's perception of the victim's threat (what is today called the "subjective" perception), rather than an actual threat, was sufficient to establish self-defense if the perception was reasonable (indeed, this was and still is known as the "appearances" rule).$^{2.8}$ Finally, it was assumed that one does not automatically provoke an incident or become an aggressor by walking into a dangerous situation or staying in a dangerous place-whether that dangerous situation is a barroom brawl or a shootout. ${ }^{259}$

I am not arguing that battered woman syndrome is unnecessary because it fits so clearly with existing self-defense law. I am questioning why battered woman syndrome has gotten so many scholars so very aggravated at absurd "subjectivism," despite the fact that, from a doctrinal perspective, its legal tenets are so conventional. Oddly, the critics know of the conventionality of the legal norms of the syndrome; they cite this, however, as a reason to increase suspicion of the syndrome as trumped-up psychology. ${ }^{260}$ The answer to that, of course, is simply to take off the veneer and get to the substance of the norms. And, if one gets there, I think it possible to make an argument-from traditional self-defense law itself-that something like the norms in battered woman syndrome testimony may be necessary to reconcile the law to its own aspirations. Under this reconception, the syndrome becomes a kind of normative equalizer, a reminder that there is no such thing as a "pre-retreat" rule or an "assumed-provocation" rule or a rule that says the victim must have left the relationship to defend against a knife hovering over her head. Put another way, the syndrome rebuts the prosecutor's arguments that she provoked the violence be-

258 King, $34 \mathrm{~F}$ at 309 ("If, with these tests applied ... the jury are satisfied that there was then an apparently imminent danger of death or grievous bodily harm to the person assailed, he is entitled to act upon the appearances.") (emphasis added); People v Fitchpatrick, 106 Cal 286, 39 P 605,606 (1895) ("It was not a matter of fact, but a matter of appearance, which measured defendant's right of self-defense."); Bruggy, $29 \mathrm{P}$ at 29 ("the right of the defendant to act upon appearances was fully and clearly stated to the jury by the court. The doctrine of apparent danger was repeatedly explained to the jury."); Maher v People, 24 Ill 241, 243 (1860) ("This court ... [has previously] held that a person when threatened with danger, must determine from the appearances and the surrounding circumstances as to the necessity of resorting to self-defense.") (citation omitted).

259 See, for example, Ball v State, 29 Tex App 107, 14 SW 1012, 1013 (1890) ("Defendant's presence at the place where the killing occurred could not, under the circumstances, constitute provocation to the deceased."). See also State v Bristol, 53 Wyo 304, 84 P2d 757, 766 (1938) (holding that the defendant had no duty to avoid entering a bar where he knew his adversary, who had threatened to attack him, to be drinking).

260 See, for example, Faigman and Wright, 39 Ariz L Rev at 88-89 (cited in note 4) ("[T]he syndrome so closely parallels the law of self-defense that its basic parameters appear to be controlled more by legal convenience than by psychological observation or theory."). 
cause she dated someone else, ${ }^{261}$ or that she could not have feared serious violence because she weathered it before, ${ }^{262}$ or that she faced no imminent threat because of the "parties' relationship." drome may not be the preferred method of addressing these problems, it is at least some protection against applying rules to battered women that do not apply outside intimate relationships.

Rethinking the syndrome as a set of relatively innocuous and perhaps necessary normative propositions may explain the odd status of the syndrome-controversial among academics because of its "bad" science, but readily embraced by politicians and judges. At the same time, however, it also raises serious questions about the intemperate claims made by some scholars. It is no exaggeration to say that some have suggested that battered woman syndrome will bring down the criminal law in its entirety. ${ }^{264}$ But if one can find reasons to support the syndrome's norms within traditional self-defense law, then opposition toward it takes on a different, and more suspiciously anti-feminist, character. Indeed, feminists must wonder whether all the controversy is about making women's claims of subjectivity strange and political so that men's claims of subjectivity may appear normal and uncontestable.

\section{Subjectivity and the State}

One of the deepest oddities in all the apparent concern about subjective defenses is that the objection is something of a phantom when it comes to self-defense law. There is no jurisdiction in the United States that adopts a purely subjective self-defense standard (for women or anyone else). ${ }^{265}$ Indeed, there are other defenses with

261 Stonehouse, 555 A2d at 781 n 5.

262 Humphrey, $921 \mathrm{P} 2 \mathrm{~d}$ at 11.

263 Watson, 431 A2d at 951.

264 See Dershowitz, Abuse Excuse at 45-47 (cited in note 3) (charging that battered woman syndrome "began" the abuse excuse and that the "abuse excuse poses real dangers to our safety and to the integrity of our legal system"). See also id at 5 (suggesting that battered woman nonconfrontational claims are vigilantism that "sow[] the seeds of anarchy and wrongdoing").

265 Even in State $v$ Wanrow, the case frequently cited as involving a "subjective" standard, the court adopted, by quoting, a rule from a 1926 case that required the honest beliefs of "reasonably and ordinarily cautious and prudent men." 88 Wisc $2 d$ 221, 559 P2d 548, 558 (1977), quoting State $v$ Miller, 141 Wisc 104, 250 P 645, 645 (1926). A purely subjective standard would, presumably, excuse a defendant based on her own fears (whether or not the fear was reasonable), and without respect to the crime charged. Although treatises, see LaFave and Scott, Criminal Law $\$ 5.7(\mathrm{c})$ at 494 (cited in note 6) sometimes suggest that there are a few "subjective" jurisdictions, the typical citation is to the Model Penal Code formulation which, in fact, includes a reasonableness qualifier. MPC $\S 3.04$ provides a defense that is based on the subjective belief of the defendant, but takes back that subjectivity with a qualifier that eliminates a complete defense if the defendant's subjective belief was unreasonable. See MPC $\$ 3.09$. Even if the defendant believes that self-defense was necessary, under MPC $\S 3.04$, he is not entitled to a complete defense if his belief in the necessity of self-defense was reckless or negligent under MPC $\$ 3.09$; instead, 
far greater claims to nearly complete subjectification-defenses about which few have complained. ${ }^{266}$ It is widely accepted, for example, that a man who kills his wife in a "heat of passion" deserves to have his subjectivity considered favorably. As I have written elsewhere, if one is concerned with subjectivity, then one's first target as an "abuse excuse" should be the provocation defense. ${ }^{267}$ The only problem is that standard criminal law scholarship has defended, or at least assumed as natural, the emotional subjectivity of men who kill because their wives cheat or leave them. ${ }^{268}$

The claim against subjectivity typically made by the objectivistthat it contradicts established law-simply dissolves once we consider provocation. Writing (quite sympathetically) of the disturbing events that led Judy Norman to kill her husband, George Fletcher complains that Norman "put herself in the position of judge and executioner," imposing a "death penalty" that no authority would have imposed. He concludes: "there may be justice in his dying, but it is not a form of justice that the legal system can readily accommodate." ${ }^{269}$ The very same arguments, however, might be said of Kenneth Peacock. ${ }^{270}$ When Kenneth Peacock found his wife in bed with another man, he got his shotgun and scared his rival off; several hours and a gallon of wine later, Peacock shot and killed his wife. Certainly, Peacock acted as "judge and executioner." We could insist, with even more fervor than Fletcher, that one does not deserve the death penalty for having sex with another. The only thing that we could not conclude is that the legal system cannot readily accommodate this kind of justice: provocation claims of Peacock's variety are an everyday affair, sanctioned in many states and by the criminal law academy. ${ }^{271}$ Subjectivity is neither new nor foreign to what most consider well-established and, for that reason, "objective" criminal law.

he may be convicted of a lesser crime, equivalent to his level of mistake.

266 I refer, in particular, here to the Model Penal Code's version of the provocation defense. See MPC $\$ 210.3 \mathrm{cmt} 3$. See also Nourse, 106 Yale L J at $1339-40$ (cited in note 85) (explaining that the Code drafters "created a defense remarkably sensitive to context and the defendant's peculiar perspective").

267 V.F. Nourse, The New Normativity, 50 Stan L Rev 1435, 1453 (1998) (noting that provocation cases cast doubt on the argument that women's claims promote abuse excuses).

268 Nourse, 106 Yale $\mathrm{L} J$ at 1364-65 (cited in note 86).

269 Fletcher, 57 U Pitt L Rev at 556 (cited in note 2).

270 See Karl Vick, Md. Judge Taking Heat in Cuckolded Killer Case, Wash Post A1 (Oct 30, 1994). To the judge assigned to this case, there was no question that Peacock suffered an adequate provocation resulting in "uncontrollable" rage: he sentenced Peacock to eighteen months to be served on work release, based on a plea of voluntary manslaughter. See Ann G. Sjoerdsma, Justice: 18 Months for a Wife's Life, Chi Trib 21 (Nov 14, 1994) ("Within two weeks of sentencing, the man is back on the road, driving his rig."). See also Lynn Hecht Schafran, There's No Accounting for Judges, 58 Alb L Rev 1063, 1063-64 (1995) (discussing Judge Cahill's sentence in the Peacock case).

271 Here, I refer to claims of provocation based on infidelity. 
My argument is not tit-for-tat. Indeed, I have some sympathy with the notion that, in a confessional age, subjectivity quickly occludes grave wrongs. What I am insisting upon is a completion of what persons mean by "objectivity." In the Watson and Peacock cases, it is rather easy to see that "time" is more than an objective reference to the clock, that, instead, it absorbs beliefs about the normal obligations of intimate partners. The Watson trial judge applied an objective rule-imminence-but meant that a woman should leave. The Peacock trial judge applied an objective rule-a continuous passion - but meant that it was not "right" to let women go unpunished for affairs. Curiously, these meanings are openly disavowed by the law-the law does not punish women for having affairs and loudly announces that we should not ask why she did not leave.

Unfortunately, there is a good deal at stake in this kind of claimed objectivity. This is not about two cases with bad judges but something a bit larger; it is about how the criminal law constitutes us and our relationship to the political order. Deeply held views about women and their relationships to men as well as their position as citizens reside in the criminal law. As I have argued above, every claim of defense is a claim not only between victim and defendant but also between the defendant and the state (was she a vigilante, a traitor to the law, an aristocrat reenacting her superiority?). When, in Watson, the trial court bars the woman's defense because she had the time to leave, this is not only a claim that she should have left her husband, but also that she failed to defer properly to the state (by choosing lawful alternatives). ${ }^{272}$ Similarly, the judgment of the court in Peacock is not only that he was "right" to punish his wife but that he was right did not offend the state-by "taking the law into his own hands.",273 Watson is a traitor and Peacock is a loyalist because the state measures allegiance by reference to relational norms. The common law's overt judgment that a woman who kills her husband is fully traitorous, ${ }^{274}$ and a man who kills to defend his marriage is partly patriot, re-

272 One might complain that the Watson and Peacock cases are not comparable because Watson involved self-defense (a full defense) and Peacock involved provocation (a partial defense). This difference does not change the claims made in this paragraph. My argument still holds if we imagine that both claims were partial defenses.

273 According to an article quoting the transcript of proceedings, the trial judge, in sentencing Peacock, stated that "the most difficult thing that a judge is called upon to do ... is sentencing noncriminals as criminals ... I seriously wonder how many married men, married five years or four years would have the strength to walk away, but without inflicting some corporal punishment." Schafran, 58 Alb L Rev at 1063-64 (cited in note 270).

274 According to Blackstone, a wife who killed her husband was guilty of petit treason and subject to be drawn and burned (rather than hanged as might a man who killed a stranger). See Blackstone, 4 Commentaries at *203-04 (cited in note 49). If a husband killed because provoked by infidelity, and thus to defend or avenge his marriage, the crime was not murder, but manslaughter. Id at *191-92: 
mains two hundred years later. Time transforms self-defense into a woman's treason; man remains aligned with the state. ${ }^{275}$ Blackstone: meet Catharine MacKinnon.

If what is wrong with the law, for women, is the law's lack of sensitivity, its failure to sympathize, women's claims may be true but they will fail to persuade. If subjectivity simply means that "my view counts, yours doesn't," it is as intolerant as an empty objectivity; it can never go beyond an "apprehension of the world as self-evident" ${ }^{, 276}$ and risks becoming the privileged knowledge of a special body of the clairvoyant. It is not sympathy that is required but humility (from both men and women), a recognition of the ways in which the law absorbs and constitutes popular norms that it does not disclose and may even disavow.

\section{WHY DO WE TALK THIS WAY?}

If there is a grammar of argumentation in criminal law, it is a grammar dominated by the "objective" and "subjective." It is not only that the current debate about self-defense is created in its mirror; it is negligence and provocation, necessity and duress, that are shaped by the demands of this opposition. The ideas of objectivity and subjectivity are pervasive and yet inarticulate. Most people assume vaguely that a subjective standard is the more progressive and an objective one the more conservative. But this overtly political consensus is a fragile one and has increasingly led to heated debates in which otherwise polite scholars have been left trading insults. In the end, I suggest in this Part that we might be better off jettisoning this discourse. Put another way, it is time to stop blaming the downfall of the criminal law on subjectivity and the battered woman; she has not created new

So if a man takes another in the act of adultery with his wife, and kills him directly upon the spot ... it is manslaughter. It is however the lowest degree of it; and therefore in such a case the court directed the burning in the hand to be gently inflicted because there could not be a greater provocation.

As one of Blackstone's nineteenth-century editors put it, with regard to these rules, "it is difficult to find any substantial grounds upon which to support Blackstone's conclusion that the female sex is a favorite of our laws." J.F. Hargrave, ed, William Blackstone, 1 Commentaries on the Laws of England *445 n 27 (Harper \& Bros 1859).

275 If Peacock committed premeditated homicide, the verdict was too compassionate; he was guilty of murder, not manslaughter. If Watson acted in self-defense, her trial court sentence of manslaughter was too harsh; she deserved acquittal. Moreover, the separate sets of rules that make this possible suspiciously parallel the situations in which men and women are, in fact, likely to kill: men tend to kill their spouses in situations where the spouse leaves or is unfaithful; women tend to kill their spouses in cases of physical violence. See Nourse, 106 Yale L J at 134252 (cited in note 86 ) (explaining various statistical claims concerning this basic difference).

276 Bourdieu, Logic of Practice at 25 (cited in note 1). 
problems, but simply reminded us of the importance of resolving old controversies.

\section{A. Confounding the Standard Distinctions}

Let us start by asking whether we really have a good idea of what the opposition between subjectivity and objectivity means. If these are taken as evaluative positions (subjective is bad, objective is good), then the distinction raises some obvious problems. One set of critics, the conservative ones, seems to believe that subjectivity is bad because it departs from good old-fashioned standards. The only problem is that good old-fashioned criminal law includes subjectivity; indeed, it has revered the subjectivity of defenses like provocation. ${ }^{27}$ Another set of critics, generally the liberal ones, complains that feminists have undermined liberalism's aim to protect defendants by taking the law too far, pushing the law to embrace absurd and abusive defenses. ${ }^{278}$ The only problem is that the syndrome gains legitimacy because it relies upon the traditional liberal emphasis on defendant-friendly individuation.

The distinction between objectivity and subjectivity fares little better at an analytic level. ${ }^{279}$ My survey was intended to be something of a test of the distinction. And, indeed, my hypothesis was borne out. What seems uncontestable and empirical, the clock, becomes questionable and normative (should Mrs. Watson have left?). What seems nondiscretionary and relatively determined becomes discretionary: we find that imminence chooses among possible meanings. What seems contextless turns out to depend upon context: imminence is structured by our assumptions about social relationships. What should be external may refer to the classically internal, the defendant's mental state (fear), and what seems so internal, a subjective standard, might actually be judged by the external rule-like criteria embedded in social norms.

Nor, in the end - and this may be the most important point-does the objectivity/subjectivity distinction work at a doctrinal level. It is an open secret that courts adopt a self-defense standard that is both objective and subjective; as a doctrinal matter, then, there simply is no debate, except at the margins. Humor me: perform a simple test. Open up a self-defense case using objectivity and subjectivity to describe

277 See Nourse, 50 Stan L Rev at 1450 (cited in note 267).

278 See Dershowitz, Abuse Excuse at 45 (cited in note 3) (asserting that the abuse excuse "all began" with battered woman syndrome).

279 The standard for the analytic difference I use is taken from Alan Wertheimer, Coercion 164 (Princeton 1987) (positing three senses of objective as "(1) external as opposed to phenomenological or internal; (2) empirical as opposed to normative; or (3) standardized as opposed to individualized"). 
self-defense law. Now black out those adjectives. ${ }^{280}$ You will probably be left with a better text and nothing will have been lost. The law can still speak of state of mind and conduct, it can even speak of the reasonable person and her perceptions, it can apply the age-old "appearances" test in self-dcfense, and announce the proper rules of aggression and proportionality. ${ }^{281}$ History makes it quite clear that the law of self-defense does not need the discourse of subjectivity for any of that.

\section{B. History: Of Norms and Mind}

We can and have lived with reasonable persons and their perceptions in the law of self-defense and elsewhere for a good long time, centuries indeed. But there has been a change in how we talk about them. Open a casebook or a treatise before 1960 and there will be no emphasis on objectivity and subjectivity. Yes, the reasonable man will appear and we will call him reasonable because of both his conduct and his state of mind, but there will be none of the discussion, in older materials, about how to frame discussions about everything from negligence to self-defense in terms of objectivity and subjectivity. Indeed, it almost appears, today, as if objectivity and subjectivity have come to substitute for the content of the criminal law. But they are a very poor substitute.

History, more than anything else, helps to explain the discourse of subjectivity and objectivity. The debate hails from a particular time

280 I began this Article, in its doctrinal section, with State $v$ Bellino, 31 Conn App 385, 625 A2d 1381 (1993), a typical appellate decision whose discussion of objectivity and subjectivity bears up quite well despite these excisions. Here is an excerpt from the decision:

The trial court began its self-defense charge by providing the jury with an almost verbatim recitation of General Statutes § 53a-19(a). This language, like that of the statute, sets forth the appropriate subjective-objective test for evaluating the defendant's belief concerning the danger he was facing. Immediately thereafter, the court provided the jury with additional guidance on the objective part of its inquiry by explaining how the jury would have to determine whether the defendant's belief was a reasonable one. The court necessarily referenced the objective, reasonable person at this stage of the instructions.

Id at 1385-86 (citation omitted). If we eliminate the references to "subjective" and "objective," we have the following:

The trial court began its self-defense charge by providing the jury with an almost verbatim recitation of General Statutes $\$ 53 a-19(a)$. This language, like that of the statute, sets forth the appropriate [] test for evaluating the defendant's belief concerning the danger he was facing. Immediately thereafter, the court provided the jury with additional guidance on [another] part of its inquiry by explaining how the jury would have to determine whether the defendant's belief was a reasonable one. The court necessarily referenced the [] reasonable person at this stage of the instructions.

281 The opposition of objectivity and subjectivity, to the extent that it focuses on the reasonable man, mistakes an evaluative claim for an epistemological procedure. The reasonable man is a way of reasoning that unifies conduct standards with particular situations. It is an intellectual procedure (much like the Rawlsian original position) in which we imagine ourselves reflectively alternating between the defendant's position and that of his fellow citizen. 
and place and has a particular problem of law in mind. Once upon a time (in the late nineteenth century), the deep normative question of self-defense-whether and how much pacifism the law must requirewas explicitly before the Supreme Court of the United States. ${ }^{282}$ Justice Holmes, ever the advocate of the objective criminal law, easily sidestepped the question. ${ }^{283}$ Refusing to decide whether retreat was required, ${ }^{284}$ Holmes, in one of his more famous passages, concluded that "[d]etached reflection cannot be demanded in the presence of an uplifted knife." ${ }^{, 285}$ With this move, Justice Holmes transformed the social and political question of necessity into a question of imminence and voluntariness, leaving retreat rules dangling and the basic question of necessity unanswered. ${ }^{286}$

Holmes's intellectual move-transforming a question of norm into one of mind-is not unique to self-defense. It is a strategy adopted by Herbert Wechsler and embodied over and over in the Model Penal Code. Consider the Model Penal Code's approach toward self-defense and imminence. Rather than eliminating the refer-

282 The parties' arguments in Brown v United States, 256 US 335 (1921), put the retreat question quite clearly to the Supreme Court. See id at 336-37 (arguing on behalf of petitioner that there was no duty of retreat at common law for a justifiable homicide - where one was feloniously attacked). See also id at 337-38 (arguing on behalf of the government that " $[t]$ he common law never recognized two species of homicide in self-defense, one justifiable and the other excusable; one dispensing with avoidance of, or retreat from, an assault with a deadly weapon, the other requiring it").

283 Id at 343. Holmes was not alone in this of course. During the second half of the nineteenth century, the term "imminence" takes on importance in courts' attempts to avoid the retreat issue. At common law, the defense of "prevention of a felony" did not require retreat; se defendendo did. Faced with two apparently conflicting common law rules - retreat or no retreatat least some courts found in imminence the way to "resolve" the contradiction. (Note that the contradiction really arises from a different source-doubts about allowing individuals to "prevent" a felony when there are public police forces.) If the threat was imminent, the courts reasoned, the retreat controversy really did not matter since the "suddenness of the attack puts him. to the wall." People v Hecker, 109 Cal 451, 42 P 307, 313 (1895), superseded in part on other grounds by statute, as stated in People $v$ Hardin, 85 Cal App 4th 625, 102 Cal Rptr 2d 262, 268 (2000).

284 See Brown, 256 US at 343 ("It is useless to go into the developments of the law from the time when a man who had killed another no matter how innocently had to get his pardon, whether of grace or of course" - this referring, of course, to the fact that se defendendo required a kingly pardon not required by prevention of a felony).

285 Id.

286 After refusing to resolve the historical dilemma on the theory that times had changed, Holmes stated as follows: "Many respectable writers agree that if a man reasonably believes that he is in immediate danger of death or grievous bodily harm from his assailant he may stand his ground and that if he kills him he has not exceeded the bounds of lawful self-defense." Id (emphasis added). From there, he concluded that one presented with "an uplifted knife" should not be deprived of a self-defense instruction because he had failed to retreat. Id. On retreat and the Holmesian position, see Kahan, 113 Harv L Rev at 430 (cited in note 10) (stating that Holmes believed "it would [have been] a waste to punish a man for not taking flight in the face of deadly aggression"). 
ence to time altogether (as the drafters had done in other places), ${ }^{287}$ the draft code places the old imminence rule firmly within the mind of the defendant. Section 3.04 specifically provides a defense for those who honestly believe the need to use force is "immediately necessary." "288 Time thus depends upon a reasonable "belief in time," and controversies about time become controversies about the reasonable man and his view of time, objective or subjective. This satisfies the liberal ideal of individuation by transforming all normative questions into questions of individual minds, but it does little to resolve the meaning of necessity.

This is but a single example of a more general trend in which the criminal law has sought to attain neutrality by avoiding difficult normative questions. This was also the preferred "neutral" solution provided by Wechsler's model code: the theory was that, if one drafts neutral laws in abstract terms and makes them clear, then we will be protected from injustice. To talk of norms in this atmosphere was thought to risk imposing the unwise and unjust judgments of the community upon a lonely and weak individual. As George Fletcher has written, the Model Penal Code was an experiment in a criminal law that purports to be precise and neutral but is without content, ${ }^{200}$ a contentlessness driven by a naive desire to prevent injustice by positive prescription.

The problem is that, as feminists have exposed, the criminal law not only oppresses openly and in positive law, but quietly and constitutively. Injustice may originate from the bottom up in the way that members of society treat each other and the ways in which this behav-

287 Indeed, the Model Penal Code is notable for its rather casual jettisoning of almost all of the common law's timing rules -in duress, necessity, and provocation. MPC $\$ 3.02(1)$ (defining justifiable conduct as "[c]onduct which the actor believes to be necessary to avoid a harm or evil to himself or to another," without requiring that the harm or evil be "imminent"); MPC $\$ 2.09$ (defining duress as an offense committed because the defendant was "coerced to do so by the use of, or a threat to use, unlawful force against his person or the person of another, which a person of reasonable firmness in his situation would have been unable to resist," without requiring an imminent threat); MPC $\$ 210.3$ (defining provocation without regard to "cooling time" as "extreme mental or emotional disturbance for which there is reasonable explanation or excuse").

288 MPC $\$ 3.04$ (1) ("Subject to ... Section 3.09, the use of force upon or toward another person is justifiable when the actor believes that such force is immediately necessary for the purpose of protecting himself against the use of unlawful force by such other person on the present occasion.") (emphasis added). This self-consciously styled "subjective" provision is then modified, in later sections, by testing whether the defendant's perceptions were mistaken and, if so, imposing liability for the negligence or recklessness of the mistake. MPC $\$ 3.09$ (2) (providing that if "the actor is reckless or negligent in having" the "belief" in the necessity of force described in $\$ 3.04$, he may be prosecuted for a crime "for which recklessness or negligence ... suffices to establish culpability").

289 This is not my characterization alone-George Fletcher would, I think, agree with me on this point about the strategy involved. See George P. Fletcher, Dogmas of the Model Penal Code, 2 Buff Crim L R 3, 14 (1998).

290 Id at 7-10. 
ior constructs human relationships. The criminal law theory of the past was obsessed with the problem of imposing state morality. What theorists failed to notice was the possibility of oppression achieved by private means sanctioned by public law. They failed to consider the possibility that, for all the worry about a misdemeanor penalty for sodomy, the law then and now may allow private persons to kill others for their homosexuality and claim, with the law's sanction, that this was "partially" justified. What is worse, a state that criminalizes sodomy or a state that allows its citizens to kill each other because they are gay? What is worse, a state assault law that omits explicit reference to battering, or a state that assumes that there are no hands around her neck? Injustice, as Judith Shklar made so clear, is as much about indifference as evil. ${ }^{291}$

\section{Protecting the Status Quo?}

If history may foretell our current obsession with subjectivity and objectivity, the present should tell us of the risks of this way of arguing. It is not only that our arguments are incomplete - that we are arguing about things we are defining quite differently, leading to inevitable misunderstanding. It is that, unless the argument is completed, it reduces to a question of power and a claim for recognition. The discourse of subjectivity and objectivity says most not about the law of self-defense or any other rule of criminal law, but about the politics of criminal law scholarship. It has become a fight between some scholars and their critics, in which each side claims that the other is guilty of exaggeration and partiality: a claim of power in which some voices say about subjectivity, "You are too soft and weak-minded to argue about the law," and the others say about objectivity, "You are too rigid and dense to see law's injustice.",292

The risk is not only that we will insult each other, but that we will ignore the ways in which law embraces contradiction and injustice. The kind of objectivity demanded by contemporary theory is doctrinepreserving. Objectivity narrows the possibilities of argument in ways that make all other normative claimants appear illegitimate, as if they were political arguments asking for special favors (because it implicitly defines objectivity as existing rules). ${ }^{293}$ This not only perpetuates

291 Judith Shklar, The Faces of Injustice 55 (Yale 1990) ("We all tend to be passively unjust.").

292 Objectivity is one kind of power, subjectivity another. Objectivity is a claim of authority, indeed a demand of recognition that relies on its author's claimed impartiality. When one says that something is "subjective," one is claiming a different kind of power. One is "right" not by distance (as the objectivist claims) but by experience.

293 This is the story of battered woman syndrome. The syndrome fit quite nicely with the ways in which liberal theory would allow normative change. And yet once this shift grew popular, 
the kind of debates we see between feminists and their critics (people say the same things over and over again) but it perpetuates the contentless nature of the criminal law. Everyone is all wrapped up in second-order arguments that look "smart" because they are abstract and no one reads the cases any more. As a result, we know less, rather than more, about the meanings, social and legal, of the substantive criminal law.

One might argue that the discourse of subjectivity and objectivity, however obfuscatory, helps to civilize our debates about self-defense law. ${ }^{294}$ If this is true of political argument, I am not sure it is true of legal argument, which in my opinion must be open about its ontological normativity. The experience of the academic debate about self-defense has not been, in my view, civilized by the discourse of objectivity and subjectivity. This way of talking has not kept scholars and courts from arguing about protecting "executioners"; indeed, it may well have encouraged such claims. There is a difference between emptiness and tolerance. If the discourse of subjectivity and objectivity represents empty claims of power, then it means that we will argue at a higher, more politicized pitch. If, however, it aims at tolerance then we must give it some content. If "objectivity" and "subjectivity" are to be more than adjectives "without portfolio," we need to talk more, rather than less, about the meanings of the criminal law.

\section{CONCLUSION}

The criminal law is not some technical arena, separated from the public institutions of our time; it is quintessentially public law, describing not only the relationship of citizens to each other but also their relation to the state. We know this, but we simply do not think of it this way. We know that no government, no constitution, no separation of powers, can protect a state from the roving band bent on private vengeance. At the same time, a state that denies the opportunity for

it took on the character of the "political." As soon as it lost its appearance as a fine respect for individuality and became a syndrome, the cries of special privilege came stronger and stronger. Put another way, the objectivity/subjectivity debate has not been kind to feminism, even though it has been perpetuated in part by feminists.

294 Dan Kahan has argued, for example, that we should not be so quick to claim that all "norms" are worth revealing or acting upon, and that the open clash of norms may undermine claims to public reason. See Kahan, 113 Harv L Rev at 487-88 (cited in note 10) (discussing the manipulation of norms). My answer here is that this has not been the case in debates about the objective and subjective - these debates have increased rather than decreased battle. My more abstract, and more complicated answer (briefly put) is that the transparency of normativity in law is a different claim than the transparency of normative content; wise restraint may prevent us from calling each other names but, in the end, claims denying that the character of an argument is normative (rather than factual) a claim of power with false intellectual pretenses. It is one thing to talk "deterrence," to keep us all in the same room. It is another to claim, and insist, that deterrence is a question of verifiable fact. 
self-defense, that asks its citizens to die rather than protect themselves, recreates the very same fears that citizens will become the slavish victims of the strong. When critics call Mrs. Norman an executioner, they are calling her a traitor, telling us that she has acted above the law; they are making, in other words, a classic political argument about the failings of citizens and their relation to the state. If one were arguing politics, the proper response would be to point to Mrs. Watson and ask whether she was a patriot to stand before an uplifted knife and risk death or imprisonment for a country that has historically failed to protect her. As lawyers and legal scholars, however, these arguments are unlikely to get us much of anywhere. Ours is the responsibility to explain, in tempered terms, what we mean about how the law of selfdefense constructs our relations to each other and the state, to civilize this discourse of necessity by something better, and more articulate, than irritated claims of "subjectivity." In a world in which more and more are investing in the power of the criminal law to determine public morality, we should take care that people may be listening. 


\section{APPENDIX: METHODOLOGY}

The survey was conducted in two phases after an initial pilot search. ${ }^{295}$ The first phase focused on decisions in which the term "imminen!" appeared at least five times (the "multi-hit" phase). ${ }^{296}$ The second phase focused on "single-hit" cases, in which the term "imminen!" might appear only once (the "single-hit" phase). The numbers that appear in the text combined phases one and two, which should represent, as nearly as possible, a universe of trial and appellate opinions on homicide and self-defense in which imminence appears as a legal issue covering the years from 1979 to 1999 . The same search was conducted for both phases; the multi-hit phase was conducted in the stand-alone LEXIS database; the single-hit phase was conducted using Lexis.com. $^{297}$

\section{A. General Terms of the Survey}

1. Cases outside the scope of the search.

Because LEXIS searches for words, it often brings up cases that are irrelevant to the inquiry but, for fortuitous reasons, involve the search terms. This requires an initial inquiry as to whether the case is within the scope of the study. For example, this search brought up civil cases as well as criminal cases that ranged from "fighting words" to labor strikes to abortion clinic boycotts.

295 The pilot search experimented with various combinations of words to avoid the "over 1000 case" message on LEXIS in the state courts database. The pilot phase began with a search from 1988 onward ("atl5(imminen!) and date(aft 1988) and "self-defense") that was found to include many irrelevant cases because it included assaults, etc. The search was refined to eliminate anything except homicide cases by adding the words ("and (homicide or murder or manslaughter)"). The search for this multi-hit phase was "at15(imminen!) and "self-defense" and (homicide or murder or manslaughter) and date (aft 1988)" and was conducted in the "states"/"courts" database of the LEXIS-NEXIS stand-alone software.

296 The initial multi-hit phase was conducted in three different date sequences. The "vanessa" search yielded a total of 171 cases from the years 1989 to 1999 . To complete a twentyyear period, additional searches were done to cover the years 1982 to 1988 (the "adam" searches) as well as to complete the years 1979 to 1982 and 1999, as the first search was done during that year (the completion searches).

297 Because of changes in the Lexis.com format and the vast number of cases, the search in the second phase was conducted by jurisdiction in the most relevant database available. The search was the same ("date(aft 1978) and imminen! and "self-defense" and (homicide or murder or manslaughter)). I say "most relevant" database because the Lexis.com platform organizes state databases differently than did the LEXIS-NEXIS stand-alone software. For example, a search in Connecticut would be done in "CT Cases, All Courts." Other states have other variations. To the extent these databases brought up cases in "irrelevant" categories, they were simply eliminated in the first cut of the coding as not relevant to self-defense or homicide. 


\section{Cases unrelated to self-defense.}

Cases involving claims unrelated to self-defense were excluded as outside the scope of the inquiry. For example, if a case raised only issues of other defenses, such as provocation or duress, it was eliminated. Only if a case involved a claim of self-defense was it included within the scope of the search (other defenses could be raised, of course). It was not enough, for example, if a case involved the term "self-defense" but the defendant was not making a self-defense argument. "Self-defense" was defined to exclude claims based on defense of others, but not imperfect self-defense.

\section{Cases not involving homicide.}

To limit the search to similar doctrinal circumstances, the search base was further limited to cases involving homicide. That was defined to include any form of murder or manslaughter, including negligent homicide. Cases were eliminated if they involved lesser crimes, such as assault or mayhem. Attempted homicides, conspiracy to commit homicide, and cases involving accomplice liability were also eliminated. ${ }^{298}$

\section{Cases deemed "relevant" on the question of imminence.}

Again, because LEXIS searches for word usage, a case in which the term "imminence" appeared would not necessarily raise an issue of imminence, even if the case was about self-defense in the homicide context. For example, it was possible that "imminence" might arise because the court was discussing the nature of self-defense in another context, such as evidentiary challenges that mention self-defense. Similarly, "imminence" might appear in a case because the appellate court cited the jury instructions and imminence was never raised again

298 One might argue that this would eliminate nonconfrontational cases arising from "hired" killings and skew the nonconfrontational sample by eliminating cases involving battered women who hire others to kill. That may or may not be true depending upon the law of the jurisdiction and the way in which charges are drafted (that is, whether the defendant is charged as a principal or an accomplice). Moreover, it would also eliminate any case involving a man who hired another to kill, claimed self-defense, and was charged as an accomplice. In fact, my survey did include cases involving battered women who hired others to kill. See, for example, People v Yaklich, 833 P2d 758, 760 (Colo App 1991) (holding that a self-defense instruction was not available in a contract-for-hire situation). I know of only one case involving a battered woman that was eliminated on this basis - it was a case, involving the killing of a sleeping man, in which it was unclear whether the defendant acted as principal or accomplice. The issue on appeal concerning imminence arose solely in the context of whether she was entitled to an instruction on self-defense in the context of the accomplice charge. See Springer v Commonwealth, 998 SW2d 439, 453-54 (Ky 1999) (holding that the battered woman defendant was "entitled to instructions on self-protection as a defense to both the principal and accomplice theories of liability").

299 See, for example, People v Coad, 181 Cal App 3d 1094, 226 Cal Rptr 386, 392-93 (1986) (discussing imperfect self-defense in the context of a decision about the impeachment of a witness by his conviction for manslaughter) (coded as irrelevant). 
in connection with the case. Such a case was not considered "imminence-relevant." Relevance here was defined broadly, however. It was not necessary that the court discussed imminence at any length or separated imminence from other issues.

A clearly relevant case would be one in which the court discussed imminence and its meaning at length or even briefly. It was also considered relevant, however, if the court discussed imminence in terms of other issues. For example, if a defendant argued that the jury instructions were too "objective" on appeal and the "objectivity" related to imminence, this was considered an "imminence-relevant" case. Similarly, if a defendant argued that he or she was entitled to expert testimony and the trial or appellate court found the expert testimony relevant-in part because of imminence-then the case was imminence-relevant. Finally, a case was considered imminence-relevant regardless of whether the imminence issue was resolved or simply returned to the lower court.

It is important to remember that a case did not need to address imminence directly in any lengthy manner to be imminence-relevant. Imminence might arise in the context of a discussion of the propriety of a question by the prosecutor, in the context of the admission of prior threats, or in the context of an argument about inconsistent defenses. These cases, as a general rule, do not discuss imminence at any length. Imminence-relevant cases are clearly not limited to cases in which imminence is considered the central or even an important issue. The case might be presented in any procedural posture, including challenges to jury instructions, appeals of sentencing, or even an application for witness fees.

Finally, it should be noted that the search was focused on the term "imminen!" rather than "immediate." "Imminence" and "imminent" are the terms typically used in the debate about self-defense and subjectivity. Searches for the term "immediate" proved difficult because the term bears both technical and nontechnical meanings. Interestingly enough, however, some jurisdictions tend to use the terms interchangeably, although this was not the intent of the Model Penal Code formulation from which the "immediately necessary" terms originate. ${ }^{300}$ Some cases from "immediately necessary" jurisdictions

300 See, for example, State v Clifton, 880 SW2d 737, 743 (Tenn Crim App 1994) (stating that Tennessee law provides that a person is justified in using force "when and to the degree the person reasonably believes the force is immediately necessary to protect against the other's use or attempted use of unlawful force. The person must have a reasonable belief that there is an imminent danger of death or serious bodily injury."), quoting Tenn Code Ann § 39-11-611 (1994); McKee v State, 785 SW2d 921, 928 (Tex App 1990) (stating the relevant self-defense question as whether deadly force was "immediately necessary to protect himself against the imminent commission by the deceased of sexual assault"). But see MPC $\$ 3.04$ (defining permissible use of force in self-protection as justifiable when "immediately necessary," as opposed to imminent). 
appear in the dataset, although there was not complete coverage of states using the "immediately necessary" formulation.

\section{Confrontational coding.}

A case was coded as confrontational based on clock time and given the defendant's allegations or facts as presented in the opinion. If there were insufficient facts reported in the opinion to make an assessment, the case was excluded from the survey. Cases were coded as confrontational based on clock time, not the nature of the threat the victim posed or any other circumstance. Thus, in some cases, the state's allegation was that the victim's actions at the time of the killing posed no threat. That case might still be classified as a "confrontational" case because the issue was not time, but quality of the threat.

Most cases represented fairly straightforward questions on this issue, although in a few cases there were doubts about the factual circumstances. These doubtful cases were coded as nonconfrontational. For example, in one case the defendant testified that she "could not remember" anything between the time of the last assault and finding her husband dead. ${ }^{301}$ Given the doubts about whether, taking as true the defendant's own allegations, there was a long or a short period of time, the case was classified as "nonconfrontational." Doubts were thus resolved against my hypothesis.

\section{Counting opinions.}

Opinions were "counted" by opinion, rather than by case, because the meaning of imminence might differ from opinion to opinion in a single case. For example, if there were two opinions in a single case, one by an intermediate appellate court and another by the state supreme court, both would be counted and coded. ${ }^{302}$ Furthermore, meanings were coded wherever they appeared in the opinion, whether in the majority, a concurring opinion, or even a dissent. Sometimes, for example, imminence is not perceived as an issue by the majority; however, the dissent, which has a different view of the case, depends upon

301 See State $v$ Koss, 49 Ohio St 3d 213,551 NE2d 970, 971 (1990) (noting that the defendant could not remember anything from the time her husband hit her to hearing a noise of gurgling blood).

302 In one instance, several appellate opinions in one jurisdiction were consolidated on appeal in the state supreme court. The court's decision was counted as one "opinion" rather than as an opinion in each of the several cases it reviewed, on the theory that we were counting legal meanings (in this case; one opinion), rather than cases. See State $v$ Studd, 137 Wash 2d 533, 973 P2d 1049, 1051-54 (1999), consolidating appeals of State $v$ Studd, 87 Wash App 385, 942 P2d 985 (1997); State v Cook, 1997 Wash App LEXIS 1145; State v Bennett, 87 Wash App 73, 940 P2d 299 (1997); State v McLoyd, 87 Wash App 66, 939 P2d 1255 (1997); State v Ameline, 1997 Wash App LEXIS 1187; State $v$ Fields, 87 Wash App 57, 940 P2d 665 (1997). 
imminence in reaching its conclusions. It would have seemed to be an inaccurate measure of the relevant "legal" meanings to discount the dissent's usage. In the interest of comprehensiveness, all opinions were counted. Opinions were not rejected from the sample because they were officially unpublished or reversed by a higher court. The point of this exercise was not to obtain controlling authority, but to measure legal meaning. Opinions at all trial and appellate levels were included in the survey. Finally, cases were coded without regard to the source of the meaning; even if a case was quoting another case, that was included as a "meaning" of the case reviewed.

\section{B. Case Coding Distinctions}

What follows explains how decisions were made to determine the meaning of imminence. Coding in both phases was done initially by legal research assistants, subject to my review. ${ }^{303}$ Coding for both iterations was completed in March 2000 and was reviewed again in January-February 2001.

\section{Threat.}

Cases classified as ones of threat were ones in which the court equated imminence with the severity or probability, rather than the timing, of the threat. A key indication here would be, for example, a statement that there was no imminent threat followed by a sentence in which the court recounts that the victim was not carrying a weapon. Also included in this category were claims that the use of violence by the defendant was disproportionate.

\section{Emotion/motive.}

Cases classified as ones of emotion or motive were typically those in which the claim was made that there was no imminent threat because the defendant acted not from fear, but revenge or deliberation. Not all references to fear or deliberation were included, but only those that could be directly tied to the question of imminence. In-

303 I made no attempt to assess coding error rates, nor to exclude my role in case review, for several reasons. First, this was a qualitative study of legal meaning, not an attempt to predict a particular quantitative usage of imminence in self-defense cases. Second, there were significant checks built into the survey in terms of the overall hypothesis (that imminence has legal meaning other than the clock). If the case was in fact confrontational, imminence was likely to bear some meaning other than the clock. Third, I sought to triangulate my research on this general hypothesis, finding work in other disciplines and within the history of the criminal law to support my general claim that time had meaning. Finally, to assure consistency of particular meanings, I required coders to support their decisions by pointing to specific text in the opinion (e.g. the term "imminence" followed by text about a lack of a weapon). I then reviewed coding decisions for consistency. 
cluded within this set of cases were claims that the defendant intended to kill if this was meant as a reference to deliberation. ${ }^{304}$ The term "intent" itself was specifically avoided for this category because of its ambiguities.

\section{Perception/appearances.}

One might argue that perception, unlike emotion or threat, does not constitute a meaning of imminence but rather an approach or angle on imminence that itself must mean time or threat. The purpose of this inquiry, however, was to try to see how courts treat the question of imminence and whether the treatment focused on time. A focus on perception is obviously not a focus on the clock but, instead, one that focuses on the defendant's mind. Perception, however, proved to be one of the trickiest of categories. It was not enough, for example, that the case simply talked about the defendant's subjectivity in connection with imminence (that might cover a healthy majority of these cases). Instead, cases in which imminence was categorized as a question of perception were cases where the meaning of imminence was not time (the case is confrontational) but really mistake-even if the victim did not have a gun, the question was whether the defendant acted on reasonable appearances. In some of these cases, the emphasis on perception seemed to be closely allied to threat. For example, the defendant and the court appeared to be assuming that the term imminence might convey the meaning of actual threat when the law only requires an apparent threat. Such cases differed, however, from those that focused on the severity of the threat, which is the standard meaning of imminence (there was no gun, therefore there was no imminent threat). In the case of situations involving perception, the question involved real versus apparent, or mistaken, threats.

\section{Alternatives.}

Cases in which imminence appeared as an alternative were cases in which the court found the threat not imminent because the defendant had other choices-running through the bathroom door, taking advantage of other opportunities for escape, etc.

\section{Aggressor/provocation.}

Cases classified under the heading of aggressor or provocation treated imminence as encompassing the principle that one who cre-

304 See Lancaster $v$ State, 472 S2d 363,365 (Miss 1985) ("He freely admits at this time he intended to kill Deputy Kirby. Under these facts ... Lancaster had no reason to believe himself to be in any imminent danger."). 
ates the conditions of the defense (provocation) or is at fault for the altercation (aggressor) should be denied the right of self-defense. On more than one occasion courts treated questions of provocation or aggression, instead, as questions of imminence. Imminence does not carry the notion of "time" in these cases but instead questions about the relative fault of the parties for the lethal altercation.

305 See Lancaster, 472 S2d at 365 ("The appellant returned now as the aggressor and, using the corner of his house and a refrigerator as obstructions between him and the deputy, fired three additional shots.... Under these facts, a reasonable jury would not disagree that Lancaster had no reason to believe himself to be in any imminent danger of bodily harm or death."). 